\title{
DON ÁLVARO SÁNCHEZ DE ÁVILA, TENENTE DE ROCHA FORTE, O LA NOBLEZA GALLEGA BAJO-MEDIEVAL EN LA TRANSICIÓN HACIA LA MODERNIDAD ${ }^{1}$
}

\author{
ÁLVARO SÁNCHEZ DE ÁVILA, 'TENENTE' OF \\ ROCHA FORTE. OR GALICIAN LATE-MEDIEVAL \\ NOBILITY ON THE TRANSITION TO MODERN AGE.
}

\author{
XOSÉ M. SÁNCHEZ SÁNCHEZ \\ Archivo-Biblioteca de la Catedral de Santiago*
}

\begin{abstract}
Resumen
La crisis bajomedieval y los cambios que el sistema feudal sufría desde dentro a partir del siglo XIV se deja sentir en todas las clases sociales de la Galicia medieval, desarrollando cada una de ellas, sus propias estrategias de adaptación y supervivencia. En el caso de la nobleza, varias son las maniobras puestas en práctica, desde la fusión con las oligarquías urbanas por vías matrimoniales a la patrimonialización de cargos concejiles. Sobre esta base, el presente artículo centra su atención en una de las principales figuras nobiliarias de la Galicia del siglo XV: Álvaro Sánchez de Ávila. Tenente de las fortalezas de A Rocha Forte y A Barreira, hombre fuerte del arzobispado de Santiago, ejemplifica a la perfección la figura del noble en la transición del período medieval a la Modernidad, en cuanto a mentalidad, posición social y relación con otros miembros de su entorno. Nuestro estudio profundiza en su figura, su actividad y todas sus implicaciones desde una perspectiva social, apoyados sobre una sólida base de fuentes documentales.
\end{abstract}

\section{Palabras clave}

Galicia, siglo XV, nobleza, sociedad medieval, economía feudal, mentalidades.

\begin{abstract}
The low-medieval crisis and the changes that the feudal system suffered from inside, from 14 th century is clear in all social classes of the medieval Galicia, developing each of them its own adjustment strategies in order to survive. In the case of the nobility there are several moves in practice, from the fusion with urban oligarchies by matrimonial ways to the apprppriation of charges of the concejo. The present article centres its attention in one of the main figures of the nobilty of Galicia in 15th century: Álvaro Sánchez de Ávila. He was the tenente of the castles of Rocha Forte and A Barreira, the main knight of Santiago's archbisphoric and he exemplifies perfectly the figure of the noble in the transition of the medieval period to the Modernity: mentality, social standing and relationship with other members of its environment. Our study deepens in its figure, its activity and all its implications from a social perspective, supported on a solid documentary sources base.
\end{abstract}

\section{Keywords}

Galicia, fifteenth century, nobility, medieval society, feudal economy, mentalities.

${ }^{1}$ Recibido/Received 03.03.2010. Aceptado/Accepted 23.05.2010

* Área de Documentación Medieval. Web institucional www.archivium-sancti-iacobi. blogspot.com; e-mail personal: xosemanoelsanchez@yahoo.es. 


\section{INTRODUCCIÓN.}

Sin duda el siglo XV constituye uno de los momentos de mayor convulsión en la historia medieval gallega. Diversos nobles, caballeros y señores feudales enfrentados por el poder a lo largo del territorio, con el arzobispado compostelano como gran pieza central. Ciertamente cada uno de tales personajes merecería, de por sí, un estudio individualizado. Pero, desde nuestro punto de vista, uno sobresale por encima de todos ellos, especialmente tras la localización de diversas fuentes documentales en el Archivo de la Catedral de Santiago que se ensamblan como un rompecabezas para ofrecernos una prístina imagen.

Fue durante la participación en el proyecto de investigación acerca de la fortaleza de A Rocha Forte, desarrollado por la Universidad de Santiago de Compostela en el año 2002 bajo la coordinación del Dr. D. Ermelindo Portela Silva y la dirección en el terreno histórico de la Dr. ${ }^{a}$ D. ${ }^{a}$ María del Carmen Pallares Méndez, cuando nos encontramos con Álvaro Sánchez de Ávila por vez primera. ${ }^{2}$ La profundización en el estamento militar a través del nobiliario de Vasco de Aponte o del Tabera-Fonseca nos condujo, como quien ilumina una antigua estancia que permanecía la oscuras, a recoger poco a poco retazos de las huellas que el teniente de A Rocha había dejado en la documentación compostelana, y a realizar un primer análisis de su figura y su contexto.

Hemos de hacer una primera precisión: el presente estudio no es una biografía, a pesar de poseer un cierto discurso biográfico en alguno de sus epígrafes y de que la línea conductora principal sea la vida del caballero en cuestión. La figura de don Álvaro no será considerada desde el punto de vista de sus hitos personales o, cuando menos, no sólo desde tal perspectiva, sino que, a través de él, consideraremos desde una visión analítica la situación de la clase nobiliaria, sus estrategias de vinculación y de obtención de recursos y el terreno de las mentalidades nobiliarias gallegas en el crucial momento de transición entre el fin de la Edad Media y el inicio de la modernidad, y, al hilo de tales hechos, elevaremos nuestro prisma para considerar estructuras más generales de la sociedad de la Galicia medieval. Creemos que la abundancia de fuentes que ilustran el personaje y emanan de su existencia nos ofrecerán un caso claro y representativo como pocos.

La vida de don Álvaro Sánchez de Ávila posee todos los ingredientes para atrapar el interés del investigador medievalista. Caballero, noble, guerrero, herido en batalla, padre, esposo... Una serie de elementos contextualizables y documentados en el mundo bajomedieval y susceptibles de un profundo análisis.

2 Emana de nuestra labor en tal proyecto el volumen Portela, Ermelindo; Pallares, M ${ }^{\mathrm{a}}$ Carmen; Sánchez, Xosé M., Rocha Forte. El castillo y su historia, Santiago de Compostela, 2004. 
Las fuentes que empleamos como base en este estudio proceden todas ellas del Archivo-Biblioteca de la Catedral de Santiago. Hemos consultado toda la documentación medieval original del ACS, examinando especialmente la Colección de Documentos Sueltos ${ }^{3}$, los pergaminos y documentos de la Colección López Ferrei$\mathrm{ro}^{4}$ y las posibles referencias en los diversos tumbos. Por medio de tal pesquisa hemos podido localizar diversas huellas, testimonios y datos que nos han ofrecido una valiosa información; destacan en nuestras fuentes:

ACS, CF 12.

ACS, CF 13.

ACS, CF 16.

ACS, S 16/13.

ACS, S 18/40.

ACS, 699 AB.

ACS, IG 425.

ACS, IG 475.

ACS, IG 476.

ACS, IG 478.

ACS, IG 702.

ACS, LD 5/1.

Pero desde nuestra perspectiva y concepción de la Historia, este conjunto de fuentes no sólo debía de ser estudiado, sino transcrito y difundido, contribuyendo a la incorporación y difusión de fuentes medievales inéditas; el proceso de edición -aunque no sea, como en este caso, objeto central del estudio- sí se nos antoja fundamental, a nivel general y de cara a renovar las fuentes con las que trabaja el medievalismo, incrementar el volumen de información disponible y salir de la consideración única de las fuentes publicadas. De esta forma nuestro conjunto de fuentes constituye un Apéndice Documental integrado por 18 documentos ${ }^{5}$.

3 ACS, S1-S13.

4 ACS, LD 5 y LD 26/1-LD 31/9.

5 Para la transcripción y edición de las fuentes seguimos las mismas normas y signos que ya en anteriores trabajos hemos definido, a saber: huecos [...], roturas ***, elementos que faltan por omisión $<>$, literalidade en la transcripción (sic), e duda en la misma (i). Optamos aquí por no separar las líneas, aunque sí indicamos las separaciones de folio -recto o vuelto- con barra /, y señalando la foliación correspondiente. Sánchez Sánchez, Xosé M., "Unha primera pedra: documentación inédita de San Xusto de Toxosoutos", Compostellanum, vol. XLVII, no 3 y 4, Santiago de Compostela, 2002, pp. 417 o Sánchez Sánchez, Xosé M., Milites Templi: A Orde do Temple na vila de Melide, A Coruña, 2006, p. 18. 
Teófilo Ruíz se refiere a don Álvaro Sánchez como "un funcionario municipal que operaba desde la fortaleza de Rocha Forte"6. Es esta una definición que dista mucho de la imagen que, en las páginas siguientes, obtendremos del tenente de A Rocha: un noble que conjugó las características más arquetípicas de la nobleza medieval y bajomedieval con algunos tintes ya más propios del estamento nobiliario de la primera modernidad. Un caballero que combina la espada con la tenencia de tierras y foros y que, especialmente, entronca con la oligarquía urbana, en este caso compostelana, y con las familias de la burguesía acomodada.

\section{DON ÁLVARO SÁNCHEZ DE ÁVILA: ORIGEN Y VIDA DE UN CABA- LLERO. LAS ESTRUCTURAS NOBILIARIAS EN LA BAJA EDAD MEDIA GALLEGA}

Hasta ahora no era demasiado lo que sabíamos sobre de Álvaro Sánchez, uno de los principales personajes de la baja Edad Media, no sólo en Compostela sino en el territorio del Reino de Galicia debido al papel que juega junto a la prelatura compostelana en los enfrentamientos del siglo XV. Conocíamos su función de tenente de A Rocha Forte, así como alguna referencia aislada en tumbos compostelanos, y poco más. Pero en este momento, con nueva documentación transcrita y nuevas referencias, se abre un amplio panorama para definir, ubicar, contextualizar e interpretar no sólo la vida sino la actividad de don Álvaro. Y todo ello tratando de superar el discurso tradicional y/o genealógico de muchos estudios acerca de la nobleza gallega, buscando entrar más a fondo en las estructuras sociales y las relaciones de la propia clase nobiliaria.

Definido en la documentación como fijodalgo ${ }^{7}$, sus apellidos, Sánchez de Ávila, parecen indicar un origen no gallego e inserto de la clase nobiliaria, quizá en un grado medio -algo aún no determinado ya que, como veremos, no tenemos localizada completamente su procedencia-. No pertenece, desde luego, a los grandes linajes y familias nobiliarias gallegas de la baja Edad Media, como los Andrade, Moscoso, Pimentel, Soutomaior, etc. En Castilla nos encontramos con una relativa abundancia de Sánchez de Ávila: el obispo coadjutor de Ciudad Rodrigo, por ejemplo, era un Alfonso Sánchez de Ávila, hacia 1428; también Alfonso Sánchez de Ávila era el presbítero abulense y capellán real en abril de

\footnotetext{
${ }^{6}$ Ruiz, Teófilo, Historia social de España. 1400-1600, Barcelona, 2002, p. 207.

7 Y prometio, conmo home fijodalgo. AD, doc. 5. Portela, Ermelindo; Pallares, M ${ }^{a}$ Carmen; Sánchez, Xosé M., Rocha, cit., doc. 5, p. 98.
} 
$1457^{8}$. Sí podemos considerar su pertenencia a la nobleza merced al cargo de tenente de a Rocha Forte que desempeñará más tarde; la tenencia de fortalezas estaba reservada, ya desde los siglos XIII y XIV, a miembros de la clase nobiliaria en sus diversos estratos, tanto en el caso eclesiástico como en cuanto a las fortalezcas de titularidad regia ${ }^{9}$.

Diversos factores refuerzan la hipótesis de un origen castellano. Por una parte la existencia de tales coincidencias, no sólo en cuanto a personajes puntuales sino en lo que atañe a linajes. Pablo Pifferrer describe con minuciosidad las sepulturas de la iglesia de Santa María de los Caballeros, en Salamanca: "Están una sobre otra con estatuas tendidas, y en la urna superior adornada de buenos follajes góticos se lee: «Sepultura del doctor Alfonso Sánchez de Ávila oydor del rey fijo de Pero Sánchez cavallero, falleció año de M y CCCCXL.» Más abajo dice otro letrero: «Estas tres sepulturas mandó fazer el doctor A. ${ }^{\circ}$ Sánchez de Ávila oydor del rey para sí y para el doctor A. ${ }^{\circ}$ Ruis su suegro y para Leonor Sánchez Guedeja mujer del dicho A. ${ }^{\circ}$ Sánchez de Ávila dotor, la que falleció año de MCCCCL años» y en la parte inferior una lápida de pizarra puesta en 1779: «Sepultura del doctor Alfonso Rodríguez Guedeja cavallero y de Leonor Sánchez Guedeja y de Paz su fija»"10.

No es simplemente la coincidencia del apellido "Sánchez de Ávila" la que nos induce a sospecha. Tal y como se refiere en esta cita la sepultura corresponde a un Alfonso Sánchez de Ávila, hijo de Pero Sánchez, caballero. Coinciden ambos antropónimos con personajes de nuestra historia: por una parte los mismos apellidos de don Álvaro y por otra, como veremos, con su hermano Pero Sánchez. Así, cabe la posibilidad de que exista una relación familiar, pudiendo responder el nombre de ese Pero Sánchez, hermano del tenente de A Rocha, al de uno de sus ascendentes más inmediatos.

Esto situaría el origen de don Álvaro en el entorno de Salamanca, aunque se trata simplemente de una hipótesis, y tampoco es la única. Encontramos documentada la casa de los Sánchez de Ávila en el entorno de la ciudad de Ávila, hacia los siglos XIV y XV, siendo dirigida, en la primera mitad del siglo XV por Sancho Sánchez de Ávila. Fueron miembros de la nobleza abulense y detentadores de

8 Nieto Soria, José Manuel, "Enrique IV de Castilla y el Pontificado (1454-1474)”, En la España medieval, no 19, Madrid, 1996, p. 201.

${ }^{9}$ Castrillo Lamas, María da Concepción, "Monarquía y nobleza en torno a la tenencia de fortalezas en Castilla durante los siglos XIII-XIV", En la España medieval, n 17, Madrid, 1994, pp. 105106.

10 Piferrer, Pablo, España: sus monumentos y artes, su naturaleza e historia, nt. 121. 
un destacado señorío, ocupando además determinados cargos de la oligarquía urbana $^{11}$.

Por otra parte, López Ferreiro se refiere a don Álvaro como "el Bayardo gallego", aunque no ofrece dato algún acerca de su origen ${ }^{12}$, al mismo tiempo que parece afirmar también un origen gallego del chantre compostelano Alfonso Sánchez de Ávila, aunque sin una mayor fundamentación ${ }^{13}$. Existen más personajes coetáneos con el mismo apellido, además del chantre Alfonso -que llegó a ser chantre y arcediano de Campos en la iglesia de Palencia-, y que nos remiten nuevamente a una procedencia castellana ${ }^{14}$ : el canónigo Nuño Fernández de Ávila ${ }^{15}$; y, especialmente destacado por la similitud antroponímica, Alfonso Sánchez de Ávila, bachiller y secretario del arzobispo don Rodrigo de Luna ${ }^{16}$.

Junto a esto, don Álvaro establece en su testamento una manda en caso de que algund herdero de Loys Domingues Tasarro, ja defunto, que bebya en terra de Campos, allende Astorga, veniere e demandare en nombre del dicho Loys Domingues ${ }^{17}$. Una señal, quizá, de una procedencia de fuera de Galicia.

Así pues, las principales referencias nos conducen a un origen castellano, vinculado con alguno de los linajes de los Sánchez de Ávila en torno a Salamanca o Ávila. Esto concordaría también con el contexto de la que pudo ser su llegada a Galicia. La primera referencia que poseemos de él es la del 5 de diciembre de 1455, siendo ya regidor de Santiago y tenente de a Rocha Forte ${ }^{18}$. La hipótesis más plausible es la de que hubiese llegado desde Castilla acompañando al nuevo arzobispo compostelano don Rodrigo de Luna, elegido en 1449. Era don Rodrigo el sobrino del condestable don Álvaro de Luna, y con él vino también una amplia compañía,

10 Piferrer, Pablo, España: sus monumentos y artes, su naturaleza e historia, nt. 121.

11 Ser Quijano, Gregorio del (coord.), Historia de Ávila. Edad Media (siglos XIV-XV), Ávila, 2006, pp. 126, 201 e 267. Un linaje, el de los Dávila, que posée sus orígenes en los grupos repobladores cristianos y que se verá consolidado y ascendido con la transformación nobiliaria del siglo XIV en Castilla. Moreno Núñez, José Ignacio, "Los Dávila, linaje de caballeros abulenses. Contribución al estudio da nobleza castellana en la Baja Edad Media", en Estudios en memoria del profesor D. Salvador de Moxó, vol. II, Madrid, 1982, pp. 157-158.

12 López Ferreiro, A., Galicia en el último tercio del siglo XV, t. I, Santiago de Compostela, 1868, p. 24.

13 López Ferreiro, Antonio, Don Rodrigo de Luna, Santiago de Compostela, 1884, p. 13.

14 ACS, CF 12, fol. [26]vo. Tumbo viejo de Aniversarios, 2.

15 Nuño Fernánez, entre otros testimonios documentales de su actividad en la institución compostelana, confirma una avenencia de 30 de marzo de 1456. ACS, CF 16, fol. XXXVIIv ${ }^{\circ}$

16 ACS, CF 29, fol. $135 \mathrm{r}^{\circ}$. Tumbo E.

17 AD, doc. 12. ACS, LD 5/1.

18 Alvaro Sanches, alcayde da Rocha Forte de Santiago et rejedor que sodes da çibdade de Santiago. ACS, S 16/1. AD, doc. 1. 
integrada por sus familiares más allegados, hermanos, primos, así como una serie de cargos administrativos, como un secretario, su alguacil mayor o el aposentador, entre muchos otros ${ }^{19}$.

Ciertamente don Álvaro en el momento de su llegada, si es que se encontraba entre los recién arribados, no poseía la influencia que tendría posteriormente a pesar de pertenecer a una familia de abolengo. En este primer momento el recién nombrado arzobispo concede la tenencia del castillo de A Rocha al arcediano de Reina y hermano de Suero Gómez de Soutomaior, Juan Mariño de Lobeira ${ }^{20}$. No se documenta todavía la presencia de don Álvaro; las posibilidades son varias: que ya estuviese en Compostela pero que aún no tengamos confirmación textual; que hubiese llegado después de Rodrigo de Luna; o que proceda de una familia gallega, algo menos probable por la inexistencia de testimonios documentales.

Por supuesto la procedencia gallega, mientras no haya una nueva referencia más clara, no está por completo descartada. Un nobiliario anónimo de época moderna hace la siguiente descripción del apellido Ávila:

Avila: su solar en Galicia, sus armas vna banda de reves con quatro quartos o jaqueles, dos de oro y los otros dos roxos entrevesados con dos cavezas de sierpe de oro en las puntas que la tragan en el bacio. Alto vna cruz azul como la de Calatrava en campo blanco y el campo del bacio bajo es azul orlado, el escudo de oro. Ay de esta familia prinzipales hijosdalgo en León ${ }^{21}$.

A partir de aquí las informaciones que poseemos soy mucho más numerosas y nos permiten realizar un análisis mucho más profundo y significativo, no sólo de la propia figura, sino, lo que creemos más importante, de su concepción de la sociedad medieval y su propio contexto.

La primera referencia documental con que contamos es el foro que el Cabildo de la iglesia de Santiago le hace, en 5 de diciembre de 1455, del coto, señorío y heredades de San Pedro de Viños, San Martiño de Calvos y Santiso de Calvos, por un precio anual de 500 maravedíes viejos ${ }^{22}$. Este es un momento en el cual Álvaro ya ostentaba el cargo de tenente de A Rocha Forte, era regidor del municipio compostelano y no había contraído todavía matrimonio, realizándose el foro por todo tenpo de vosa vida et da primera moller que ouberdes et con que casardes, et sole-

\footnotetext{
19 López Ferreiro, A., Historia, cit., t. VII, p. 193.

${ }^{20}$ Ibidem, p. 193.

21 ACS, LB 23.

22 AD, doc. 1. ACS, S 16/1.
} 
nizardes casamento et desposorio ${ }^{23}$. Este foro había sido realizado gracias a la mediación del arzobispo, tal y como si recoge en el Tumbo de tenencias de la Iglesia de Santiago, refiriendo que ouveos con roos et favores do sennor arçobispo don Rodrigo de Luna, con quen el vivia ${ }^{24}$. La relación con el prelado era muy estrecha, hasta el punto de compartir, al menos según este testimonio, residencia -en referencia, quizás a Rocha Forte-.

Lo que sí sabemos es que don Álvaro Sánchez tenía un hermano. En el testamento de García, escudero del conde de Trastámara don Pedro Álvarez Osorio, otorgado el 11 de julio de 1459, encontramos un pasaje en el que don Álvaro se torna protagonista. Se refiere aquí que el ya tenente de A Rocha tenía un hermano, Pedro Sánchez, el cual habría entrado, al igual que don Álvaro, al servicio del arzobispo de Compostela. Según el testador ese Pedro Sánchez, envalentonado probablemente por la posición de privilegio de su hermano, habría robado el caballo al propio García; un episodio nada amistoso, puesto que el texto alude a ciertas heridas inflingidas, aunque no podamos afirmar que tuviese relación directa con el robo. En cualquier caso tal cuestión trajo como consecuencia un tira y afloja que dio con Pedro Sánchez, yrmaao de Alvaro Sanchez, alcalde da Rocha, apresado por los hombres de García ${ }^{25}$.

Manteniendo probablemente una conciencia todavía linajística, es don Álvaro quien se encargó de solucionar la situación, pagándole a García por el agravio una cadena de oro de sesenta reales de peso ${ }^{26}$ y alcanzando así la liberación de su hermano -cadena que, como se cuenta en el testamento, terminaría vendiendo-.

En el tiempo entre este momento y las guerras irmandiñas de segunda mitad del siglo don Álvaro no sólo contrae matrimonio sino que tiene su primer hijo, datos que conocemos gracias a la toma de posesión que realiza en nombre de ese vástago, Gil Rodrígues Barela, sobre diversas propiedades en Palavea (San Vicente de Elviña, A Coruña), el 7 de noviembre de $1471^{27}$. Tal y como se especifica en la toma de posesión, esta fue realizada por Álvaro Sánchez en nome de Gil Rodrigues Barela, seu fillo, e de Maria Gonçalves, sua moller, filla legitima da horrada donna Elvyra Fernandes, vesina desta dita çibdade, defunta, que Deus aja, moller que fuy de Gil Rodrigues Barela, regidor da dita çibdade de Santiago ${ }^{28}$.

$23 \mathrm{AD}$, doc. 1. ACS, S 16/1

24 AD, doc. 4. ACS, CF 16, fol. VIIIv'.

${ }^{25}$ Eu tomey e prendin a Pero Sanches, yrmaao de Alvaro Sanchez, alcalde da Rocha. AD, doc. 2. ACS, $699 \mathrm{AB}$, fol. $194 \mathrm{r}^{\circ}$.

$26 \mathrm{AD}$, doc. 2. ACS, $699 \mathrm{AB}$, fol. $194 \mathrm{r}^{\circ}$.

27 AD, doc. 6. ACS, S 18/40.

28 AD, doc. 6. ACS, S 18/40, fol. $1 r^{\circ}$. 
Don Álvaro se casa, así, a finales de los 50 o a lo largo de los años 60 con María González, hija de Gil Rodrigues Barela, un miembro de la oligarquía urbana de Compostela, y uno de los regidores de la ciudad, al igual que nuestro protagonista. Más adelante analizaremos las implicaciones de este matrimonio desde el punto de vista socioeconómico; baste decir por ahora que María González será la única esposa con la que engendrará don Álvaro. En este momento, Gil Rodrigues, su hijo, era todavía menor, de ahí que su padre tome posesión en su nombre de las propiedades en el entorno de A Coruña.

De esta forma, don Álvaro alcanza un cierto patrimonio por vía matrimonial, ya que sus suegros ya habían fallecido: Gil Rodrígues lo había hecho en algún momento antes de esta toma de posesión ${ }^{29}$, y su esposa podia aver tres o quatro dias pouco mays o menos tempo que a Elvyra Fernandes, aboa legitima do dito Gil Rodrigues, [...] falesçeu desta presente vida ${ }^{30}$. Estas posesiones pertenecían a su ya fallecida suegra, Elvira Fernández y, tras su fallecimiento, pasaban a su nieto, aún menor y por lo tanto bajo la tutela de don Álvaro.

Perdemos aquí la pista de María González, ya que el 31 de agosto de 1472, siete meses después, el Cabildo concede permiso a sus procuradores para recibir los pagos de las fianzas sobre la tenencia de Reis por parte de Inés García, moller de Alvaro Sanches, regidor da çibdat de Santiago ${ }^{31}$; cabría la posibilidad de alguna duda acerca del personaje de no ser porque, en ese mismo año el Cabildo concede las propiedades de dicha tenencia a don Álvaro, con un título muy claro en el Tumbo compostelano de Tenencias: Contrato do alcalde da Rocha sobre a tenençia de Reys $^{32}$.

Prescindiendo por ahora de los elementos económicos que implica esta documentación lo que nos interesa es el hecho de que en el lapso de tiempo entre noviembre de 1471 y agosto de 1472 el matrimonio entre don Álvaro y María González se deshizo, siendo la hipótesis más plausible la del fallecimiento de ella, y que don Álvaro se vuelve a casar, con esta Inés García, una mujer de recursos económicos cuando menos suficientes para mantener un determinado estatus, ya que es ella la que paga esa fianza para la tenencia de Reis.

Aunque lo trataremos más adelante, debemos de destacar ya ahora una característica importante en el caso de don Álvaro: el matrimonio con dos mujeres cuyas

${ }^{29}$ Gil Rodrigues Barela, regidor da dita çibdade de Santiago, que Deus aja. AD, doc. 6. ACS, S $18 / 40$, fol. $1 r^{\circ}$

30 AD, doc. 6. ACS, S 18/40, fol. $1 r^{\circ}$.

31 AD, doc. 8. ACS, IG 475, fol. CXXVr'

32 AD, doc. 9. ACS, IG 475, fol. CXXIXr'. 
familias estaban integradas en la burguesía urbana, elemento arquetípico de la transición de la baja Edad Media a la modernidad en la nobleza de título, que buscaba así un asentamiento económico que flojeaba, mientras para el sector burgués y oligárquico proporcionaba un título que no adquirirían de otro modo.

En estas décadas de los 60 y 70, Álvaro Sánchez de Ávila parecía poseer y asumir una concepción muy fuerte del poder señorial, poco menos que omnipotente en su territorio; este territorio se nucleó en el entorno de la fuerte de A Rocha Forte, de la cuál es alcaide durante buen parte del siglo XV por nombramiento del arzobispado de Santiago.

En tal concepción encontramos varios elementos presentes ya en la nobleza plenomedieval y que ahora, aunque mutados, continúan presentes. En el testamento de don Álvaro, realizado en 1489, se especifican una serie de mandas otorgadas a los hijos de determinados personajes que están en su casa: mando a los fijos de Ortiz que estan en mi casa, a cada vno, su luto e mill partes de blancas. Iten mando a la fija de Presedo, que esta en mi casa, su luto e tres mill partes de brancas ${ }^{33}$; ésta era una práctica muy en la línea de la nobleza medieval, el hecho de criar en casa propia a los hijos de otros, así como hacer criar fuera a los propios -algo de lo que no tenemos constancia en el caso de Gil Rodrígues, aunque, como veremos, la razón puede ser en cierta forma trágica-. La crianza de los niños fuera de casa, ya sea con parientes, como los tíos, o con otros nobles, se encuentra documentada desde el siglo XII y pervive hasta el XVI ${ }^{34}$. A esto se une la presencia en muchos casos de amos/amas de cría, con los cuales se crea una especial relación y que aparecen muchas veces como destinatarios de mandas en los testamentos nobiliarios ${ }^{35}$. Puede ser el caso de Juan de Zubyo y su esposa, que crían a Isabel Sánchez, Beliça, nieta de don Álvaro; éste dispone en su testamento que se den a Juan Zubyo e a su mugier, que han criado mi nieta Beliça, çinco mill maravedis pares de blancas, e que les den sus lutos como los otros mis criados ${ }^{36}$.

Por otra parte, en algunas versiones de determinados episodios protagonizados por Álvaro Sánchez de Ávila, encontramos presentes y definidas ciertas características de la nobleza caballeresca bajomedieval que aparecían formuladas ya en diversas obras literarias. Cuando don Álvaro es apresado por Diego de Andrade, en la batalla de Altamira, en 1471, y llevado a Pontedeume, éste le permite acudir a Santiago bajo promesa de retornar por su honor; una promesa que cumple, ante lo

33 AD, doc. 12. ACS, LD 5/1, fol. 2v‥

34 Beceiro Pita, Isabel; Córdoba de la Llave, Ricardo, Parentesco, poder y mentalidad. La nobleza castellana siglos XII-XV, Madrid, 1990, p. 111.

35 Ibidem, p. 113.

${ }^{36} \mathrm{AD}$, doc. 12. ACS, LD 5/1, fol. $2 \mathrm{v}^{\circ}$. 
cual es liberado. Es así como nos refieren el episodio Vasco de Aponte y, más recientemente, Salustiano Portela Pazos ${ }^{37}$; probablemente haya mucho de literatura en esta narración pero también de concepción nobiliaria: una concepción de honor como valor destacado del caballero por encima de todo. Honor hacia su señor, hacia la batalla, con el elemento militar como básico, manteniendo todavía una conciencia de bellatores y de honor con la palabra dada a un igual.

También la consideración de las relaciones sociales que Álvaro mantiene refuerzan esta idea. Como se expresa en su propio testamento, él era cargo y tutor de los hijos de los escuderos Vasco Pérez de Vaamonde y Juan Francisco de Salnés, así como de los de Pedro Manso, armero ${ }^{38}$. Una serie de personajes vinculados, todos ellos, al mundo militar del entorno compostelano y a un grupo muy definido por la guerra, en este momento, como principal medio de vida.

Confluyen así, en don Álvaro Sánchez, aspectos de la nobleza feudal y de la nobleza caballeresca bajomedieval; aspectos muchos de ellos no sólo visibles en Galicia sino en la nobleza, en general, de la Europa Occidental medieval ${ }^{39}$.

Por otra parte, la organización familiar, aunque no se alude en ningún momento a su linaje como tal, resulta de interés para considerar las estructuras familiares nobiliarias del bajo medievo. Los factores que, según la periodización de Isabel Beceiro Pita ${ }^{40}$, enmarcan de modo general la transición hacia un sistema parental agnaticio en el siglo XIII - mediados del XIV, son comparables al contexto gallego del siglo XV. Tal cambio y evolución, a nivel peninsular, se ve marcado por una serie de elementos perfectamente definidos: la formación de la oligarquía aristocrática que se sitúa por encima de la propia nobleza; el incremento de los dominios nobiliarios y de las propias atribuciones señoriales de los titulares; el aumento, igualmente, de las concesiones hereditarias; y la oposición y confrontación entre los diversos sectores aristocráticos y entre estos y la monarquía ${ }^{41}$.

Considerando el caso gallego hacia el siglo XV, y desenrollándose a lo largo de la centuria, observamos esa configuración de una nobleza con los principales lina-

37 Portela Pazos, Salustiano, Galicia en tiempo de los Fonsecas, Madrid, 1957, cit., p. 83.

38 AD, doc. 12. ACS, LD 5/1, fol. 3ro .

39 Recordemos obras como las de Chrètien de Troyes, ya desde el siglo XIII, la Vulgata artúrica en el XIV o las de Sir Thomas Malory, en el XV, recogiendo y ensalzando este tipo de valores nobiliarios.

40 Beceiro Pita, Isabel; Córdoba da Llave, Ricardo, Parentesco, cit., p. 63.

41 Ibidem, p. 63. Los autores añaden también otros elementos como la incorporación de la Andalucía Bética y Murcia al reino de Castilla o la detención del ritmo de la reconquista hasta los Reyes Católicos, factores que, creemos, en el caso gallego poséen una influencia muy relativa. 
jes del territorio representados en ella (Andrade, Soutomaior, etc.); unos linajes que por medio de concesiones anteriores, añadidas a adquisiciones propias incrementan sus dominios, aumentando además la presión señorial sobre otros sectores sociales. Sobre esta base el enfrentamiento entre los sectores aristocráticos se encuentra profundamente presente en el último siglo medieval gallego, así como el enfrentamiento con un poder principal como protagonista, que en este caso no es la monarquía pero sí el arzobispado compostelano.

Las nuevas formas de parentesco nobiliario en la baja Edad Media, a nivel peninsular, vienen marcadas por la primogenitura en la sucesión en la cabeza de la casa, la masculinidad y el seguimiento de una línea troncal ${ }^{42}$; unas características ya apreciables en Castilla desde mediados del siglo XIII y comienzos del XIV ${ }^{43}$. Tal sistema de parentesco es opuesto al plenomedieval, que estaba marcado por un concepto más amplio en el cual la conformación del linaje todavía no se había producido, y por una organización bilineal y cognaticia; un sistema que en Galicia tiene en el grupo familiar de los Traba su ejemplo más perfecto ${ }^{44}$.

La del linaje y de las nuevas formas familiares es una lenta conformación no culminada hasta el siglo XV; los mayorazgos surgen hacia finales del siglo XIII como formas de transmisión de la propiedad $-\mathrm{y}$ de la conciencia de linaje ya a mediados de la centuria- ${ }^{45}$, aunque es en la baja Edad Media cuando cobran verdadera fuerza y calado en la nobleza.

$\mathrm{Al}$ desarrollo de la idea de linaje se asocian otros comportamientos, algunos de los cuales, en el caso de don Álvaro Sánchez, son perfectamente visibles. Nos referimos por ejemplo a la sucesión de apellidos e incorporación de antropónimos (Sánchez de Ávila) o, especialmente, a la integración de vasallos y criados en un grupo cerrado como sería la casa ${ }^{46}$, la cual posee una designación concreta por medio del nombre del grupo familiar ${ }^{47}$; un proceso culminado y asentado, como decimos, hacia mediados del siglo XV. En el testamento de don Álvaro, en el desen-

42 Ibidem, p. 68.

43 Ibidem, p. 68.

${ }^{44}$ En relación con tal grupo "el examen da transmisión de bienes, o estudio da herencia [...], no sólo confirma la inexistencia del linaje, sino que ofrece buenas pruebas de una ordenación diferente". Pallares, María del Carmen; Portela, Ermelindo, "Aristocracia y sistema de parentesco en la Galicia de los siglos centrales de la Edad Media. El grupo de los Traba", Hispania. Revista española de historia, vol. LIII, 185, 1993, p. 838.

45 Beceiro Pita, Isabel; Córdoba de la Llave, Ricardo, Parentesco, cit., p. 73.

46 Ibidem, p. 75.

47 Algo que no ocurre en los grupos familiares plenomedievales, como los Traba hacia mediados del siglo XII. Vid. comparación entre Traba y Soutomaior en Pallares, María del Carmen; Portela, Ermelindo, "Aristocracia", cit., pp. 824-825. 
rollo de mandas testamentarias, encontramos a doce criados y personas que se verían integradas no en su familia ni linaje, pero que sí podríamos considerar como casa. Algunos de ellos son los criados de servicio, como María, mi criada de serviçio de casa ${ }^{48}$-aunque en esta frase dicho término posee el sentido de lugar de habitación-.

Mientras que el núcleo familiar es relativamente reducido y el del linaje es mucho más amplio, el concepto de casa engloba a todos los dependientes de una persona -lo cual no tiene por que implicar necesariamente ningún tipo de relación económica sino, por ejemplo, un juramento de fidelidad-. Un gran número de personas pertenecen a la casa de don Álvaro pero ni mucho menos se integran en su linaje.

La casa va más allá de relaciones sanguíneas. Estamos haciendo referencia a estructuras que surgen todavía en el pleno medievo, relacionadas en sus primeras formas con el feudalismo del terreno francés y que desde los siglos XII-XIII se difunden y continúan evolucionando hasta estas formulaciones ya bajomedievales de los elementos feudales.

En este contexto don Álvaro, como jefe de su casa, se preocupa y dispone también ayudas para las criadas casaderas, estableciendo una dote en el momento de su matrimonio. Así establece que le den a la fija de Presedo, que esta en mi casa, su luto e tres mill partes de brancas, que le den quando se desposare por palabras de presente con el que oviere de ser su marido ${ }^{49}$.

Este sistema de mandas orientadas a los parientes colaterales y a los criados, haciéndolos partícipes de la herencia por medio de pequeñas porciones de propiedades o de bienes, con pequeñas participaciones monetarias o, en o caso femenino, objetos para el ajuar, fue el sistema más común empleado por la nobleza bajomedieval de cara a estos grupos de segundo y tercer grado, por debajo de los hijos legítimos y parientes directos ${ }^{50}$.

Criados referidos en el testamento de Álvaro Sánchez de Ávila.

\begin{tabular}{|c|}
\hline Álvaro de Caamaño \\
\hline María de Finojedo \\
\hline Fernando de Presedo $^{51}$ \\
\hline
\end{tabular}

\footnotetext{
48 AD, doc. 12. ACS, LD 5/1, fol. $2 v^{\circ}$.

$49 \mathrm{AD}$, doc. 12. ACS, LD 5/1, fol. $2 \mathrm{v}^{\circ}$.

50 Beceiro Pita, Isabel; Córdoba de la Llave, Ricardo, Parentesco, cit., p. 249.

${ }^{51}$ Hijo de Juan de Presedo padre, el cual es posible que haya sido criado de don Álvaro antes que el fillo.
} 


\begin{tabular}{|c|}
\hline Rodrigo Arias \\
\hline Francisco Clérigo \\
\hline Gómez de Ponte \\
\hline Arias \\
\hline María ${ }^{52}$ \\
\hline Ignacio \\
\hline Diego \\
\hline Francés \\
\hline Rodrigo \\
\hline
\end{tabular}

Fuente: ACS, LD 5/1.

En todo este contexto la referencia a la ayuda de Pedro Sánchez a su hermano en las correrías por la tierra de Santiago, se inserta perfectamente en la función que los parientes consanguíneos desempeñan en la casa nobiliaria ${ }^{53}$. Esta relación no sólo obliga al titular, jefe o representante principal, sino al devenir del propio linaje; de esta forma dichos parientes, beneficiados por la actividad de ese representante -en este caso don Álvaro Sánchez de Ávila- adquieren los mismos deberes y obligaciones que él. Así encontramos a Pedro cabalgando junto a su hermano por la Tierra de Santiago.

Ciertamente, y debemos señalarlo, también hay elementos que no encontramos en el caso de don Álvaro; no existe aquí un señorío como tal en el que un linaje asiente su poder señorial en la administración y gobierno; no encontramos, tampoco una figura mítica o de referencia como origen del linaje ${ }^{54}$, aunque sí se documenta una determinada concepción de la familia y de la casa, presente en su testamento. De ahí que consideremos a don Álvaro como un buen ejemplo de la baja nobleza en la transición hacia la modernidad, aunque teñido de algunas concepciones mentales que parecen propias de la aristocracia plenomedieval.

A lo largo de este período tampoco nos resulta desconocida la vida más o menos cotidiana de Álvaro Sánchez de Ávila. Conocemos su actividad como tenente de Rocha Forte, de forma que en muchas ocasiones ésa sería su residencia relativamente cotidiana, más allá de los momentos de crisis, como los asedios que sufrió la fortaleza en la segunda mitad del siglo XV.

Pero no olvidemos su otro cargo: regidor de la ciudad de Santiago. Así, don Álvaro con seguridad alternaba la estancia en el castillo con la residencia en la

52 Criada de servicio de casa.

53 Ibidem, p. 323.

54 Ibidem, pp. 88-89 e 105. 
ciudad; una residencia que cobra mayor importancia en el momento en que el castillo de A Rocha es asediado, vencido y derribado, siendo llevada la piedra para la edificación de la torre del Pico Sacro por orden del arzobispo don Alonso de Fonseca $\mathrm{II}^{55}$.

A esta vivienda urbana se hace alusión en una nota del compostelano Tumbo III de Tenencias, redactado en el siglo XV, informando de que don Álvaro residía en unas casas en la calle Da Moeda Vella, en la ciudad de Santiago, calle limítrofe con el monasterio de San Martiño Pinario. En el tumbo, bajo el epígrafe Enna Rua da Moeda Vella, y aludiendo a unas casas pertenecientes a la Tenencia Grande del Cabildo, se refiere que elas estan juntas fiestras por fiestras con as casas que estan da outra parte et foron de Afonso Vaasques Abril, et son agora do alcayde da Rocha et mora en elas ${ }^{56}$. Reparemos en la aclaración de que no sólo las casas son de propiedad de don Álvaro sino que vive en ellas.

Y así transcurrió su existencia. Como veremos más adelante la férrea defensa de sus propios intereses económicos, aprovechándose de su condición de favor como tenente de A Rocha y hombre de confianza del arzobispado, le granjearon ciertas enemistades con miembros del Cabildo; canónigos que buscaban más rentabilidad para las propiedades aforadas que las reducidas rentas que don Álvaro les pagaba en los años 60 de la centuria, pero ante lo cual no podían hacer nada por el favor arzobispal del que el caballero gozaba ${ }^{57}$. Posee, la figura de Álvaro, una innegable similitud con otro noble gallego, Gómez Pérez das Marinas, que a mediados de siglo fue tenente de la fortaleza de A Coruña y regidor del municipio, así como acusado de abuso en ambos $\operatorname{cargos}^{58}$. Otro ejemplo de dominio y poder efectivo y político.

El tiempo fue pasando y Álvaro Sánchez de Ávila se erigió, a lo largo de los años 60, en verdadero adalid y defensor del arzobispo don Alonso de Fonseca II,

55 Portela, Ermelindo; Pallares, Ma Carmen; Sánchez, Xosé M., Rocha Forte. El castillo y su historia, Santiago de Compostela, 2004, p. 79. Se considera, entre otros, el testimonio de Juan de Silva, del Tabera-Fonseca.

56 La transcripción completa es: Enna Rua da Moeda Vella [...] Estan estas casas enno começo da Rua que vay para o Campo, dexando duas casas pequenas novas do Cabildo; logo elas estan juntas fiestras por fiestras con as casas que estan da outra parte et foron de Afonso Vaasques Abril et son ahora do alcayde da Rocha et mora en elas. ACS, CF 16, fols. XVIIvo-XVIIIr ${ }^{\circ}$. Tumbo III de Tenencias.

57 De hecho, como ampliaremos más adelante, ante la voluntad de renegociar la posesión de los cotos de Santiso y Oins para aumentar la renta, hacia 1463, el propio arzobispo don Alonso de Fonseca II parece intervenir, aunque sen hacer demasiado ruido, y aplaca tales reivindicaciones. AD, doc. 4. ACS, CF 16, fol. VIIIvo.

58 Sánchez Chouza, José Manuel, A Coruña en la baja Edad Media, A Coruña, 2005, p. 118. 
siendo brazo ejecutor de su política y uno de sus más fieles y audaces caballeros. Hacia 1466 A Rocha es asediada y vencida, y don Álvaro deja de ser el tenente de este Castell Sant'Angelo compostelano. Mantiene aún así su influencia, tanto militar como económica y política, pero la edad no pasa en balde, y para los guerreros menos, como don Álvaro comprobaría pronto. En 1471, con su participación, tiene lugar una de las principales batallas de la época más convulsa de la Galicia bajomedieval: la batalla de Altamira, el día 13 de junio. Lope Sánchez de Moscoso, señor de la casa de Altamira, levantado en armas contra el prelado de Santiago Fonseca II, había conseguido erigir, hacía poco tiempo, un castillo en el propio lugar de Altamira ${ }^{59}$, un enclave que se consideraba estratégico y, por tanto, de enorme peligro para el arzobispo compostelano.

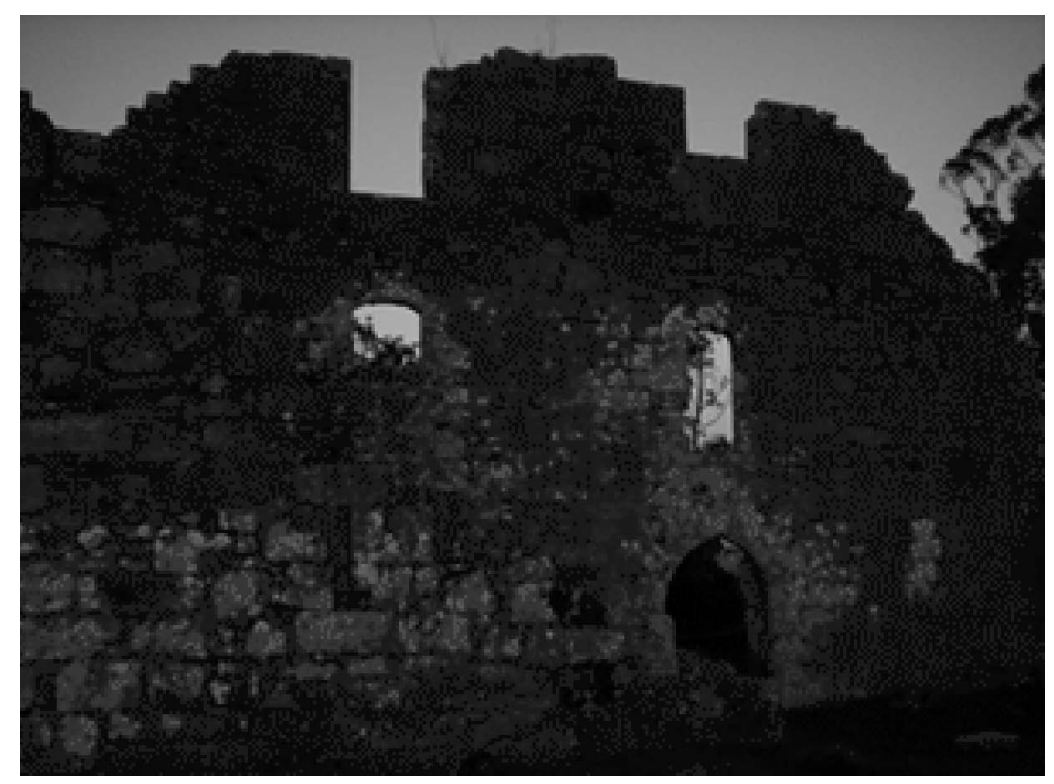

Fortaleza de Altamira (Brión, A Coruña), campo de batalla en 1471.

Según Vasco de Aponte, cerca de cinco mil peones bien pertrechados, con dos trabucos, sei juntaron para asediar la fortaleza, con armas de los Maldonado y de los Fonseca, y enfrentados a Pedro Álvarez de Soutomaior, Diego de Andrade y Gómez Pérez das Marinas, que acudían en defensa de Lope Sánchez.

59 Portela Pazos, Salustiano, Galicia, cit., pp. 81-82. 
En tal contienda el pendón del arzobispo compostelano era portado por el que debía de ser su más bravo caballero, Álvaro Sánchez de Ávila. El episodio protagonizado por el alcaide de A Rocha se ve marcado por tintes épicos y caballerescos, y aparece referido en uno de los tumbos de la catedral compostelana, aunque sin mencionar al propio personaje:

Anno Domini $\mathrm{M}^{\circ} \mathrm{CCCC}^{\circ} \mathrm{LXXI}^{\circ}$, a treze dias do mes de junio foy a batalla de Altamira, et que que foy en dia quynta feira que era dia de Corpus Christi et de Santo Antonio, entre o arçobispo de Santiago et todolos cavaleiros de Galizia. Et foy desbaratado o arçobispo et tomado o pendon de Santiago et rasgarono et levarono os cavaleiros en seu poder et dende a çertos dias fezeron conçerto delo, et hua noyte deitaronlo enno altar de Santiago ${ }^{60}$.

También Vasco de Aponte recoge la contienda en la más propia tradición bajomedieval de los relatos de caballería:

Mas su alférez [del arzobispo] quedó con el pendón solo en el campo, que era el muy honrado castellano Álvaro Sánchez de Ávila. Cargaban todos los contrarios sorbre él, mas nunca le pudieron quitar el pendón de las manos hasta derrocarle y ferirle en la cara y en las manos; pero en el cuerpo no le pudieron ferir, porque iba muy armado; pero dábanle tan grandes golpes por encima de las armas, que lo facian enfraquecer, y lo mataran de todo punto, si no fuera el señor Diego de Andrade, que se lo sacó de las manos, porque no quería alargar el pendón, y llevolo a su tienda y lo hiço curar y lo trajo a la Puentedeume y sobre su fe dejolo venir a Santiago, y porque volvió al tiempo que prometió, soltolo sin rescate y inviolo para su casa libre y quito ${ }^{61}$.

Era, pues, don Álvaro el abanderado y portador del pendón del prelado compostelano, como correspondería a su posición sin duda destacada dentro del ejército arzobispal. Según estas versiones incluso con la batalla casi perdida, con un ejército asediando y rodeado de atacantes, resiste como puede hasta que, ya herido, le

60 ACS, CF 12, fol. [68]r ${ }^{\circ}$. Tumbo Viejo de Aniversarios, 2. Ya recogido por López Ferreiro, A., Historia, p. 270, nt. 1 y Portela Pazos, Salustiano, Galicia, cit., pp. 82-83.

61 VA. 
arrebatan el pendón. Aún sin la tenencia de A Rocha, don Álvaro continúa siendo uno de los más fieles caballeros y principales adalides del arzobispado compostelano.

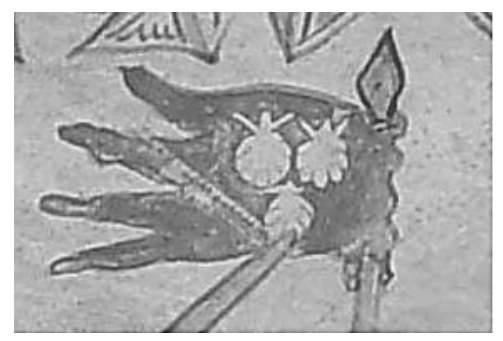

Pendón arzobispal, enarborado por el Apóstol en defensa de don Berenguel de Landoira. Fuente: ACS, Tumbo B, fol. $2 \mathrm{v}^{\mathrm{o}}$.

Así, el jueves 13 de junio del año $1471^{62}$, día de Corpus Christi, los dos ejércitos se enfrentaron en cruento combate frente a los muros de la fortaleza y torres de Altamira, sobre su foso. Una batalla en la que las huestes arzobispales reciben una dura derrota; pero don Álvaro, fiel a su condición de bellator, se resiste a ser vencido, según refiere Vasco de Aponte, siendo atacado y herido por varios caballeros pero negándose a entregar el pendón ${ }^{63}$.

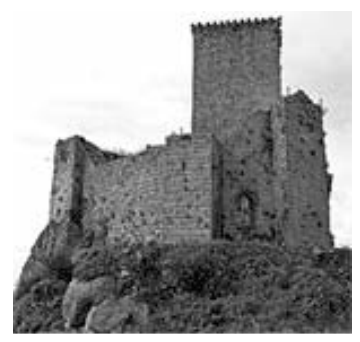

Castillo de los Andrade (Pontedeume, A Coruña), donde Álvaro Sánchez permaneció retenido aunque ayudado por Diego de Andrade.

62 Anno Domini $\mathrm{M}^{\circ} \mathrm{CCCC}^{\circ} \mathrm{LXXI}^{\circ}$, a treze dias del mes de junio foy a batalla de Altamira, et que que foy en dia quynta feira que era dia de Corpus Christi et de Santo Antonio, entre el arçobispo de Santiago et todolos cavaleiros de Galizia. ACS, CF 12, fol. [68] $\mathrm{r}^{\circ}$. Tumbo Viejo de Aniversarios, 2. Recogido también en López Ferreiro, A., Historia, p. 270, nt. 1 y Portela Pazos, Salustiano, Galicia, cit., p. 82.

63 VA. 
Diego de Andrade, viéndolo desfallecer, herido en la cara y en las manos, lo condujo preso a su tienda y desde ahí partieron hacia Pontedeume, a la fortaleza de los Andrade, donde don Álvaro permanecerá un tiempo retenido y se curará de sus lesiones. Pasarán años hasta que volvamos a encontrar una referencia documental de don Álvaro relacionada con el terreno militar; desde este momento y por un amplio período de tiempo únicamente aparece en documentos más o menos administrativos, como tomas de posesión, foros, fieldades y, hasta su muerte, siempre asociado a su título de regidor de la ciudad de Santiago así como a una función que hasta ahora no se había destacado lo suficiente, en un nuevo servicio a su señor compostelano.

La recuperación de las heridas de la batalla de Altamira seguramente había llevado su tiempo, pero Álvaro aún no estaba cansado de una vida siempre próxima a la espada y a los muros de un castillo. Incorporamos ahora un dato que hasta hoy pocas veces se había asociado a este personaje, a pesar de tratarse de una referencia ya conocida. La experiencia de Álvaro Sánchez al frente de un enclave militar era mucha y, con seguridad, desde el arzobispado de Santiago no se quería desaprovechar; es por esto por lo que, en 1481, en el Libro de Recabdança del Archivo de la Catedral de Santiago, lo encontramos mencionado como alcaide y tenente de la fortaleza de A Barreira, refiriéndose a él no sólo por su nombre, sino también como alcaide de A Rocha, cargo que sin duda, aunque ay cumplido, no se olvidaba.

Ahí, al frente nuevamente de un destacamento militar, a las órdenes de don Alonso de Fonseca II, y desde los almenados muros de un castillo, permaneció don Álvaro un relativamente amplio período. Ciertamente desconocemos cuanto, pero sí sabemos que dejó la tenencia del enclave todavía con vida, seguramente acuciado por la edad, y en cualquier caso antes de 1489, ya que en ese año tuvieron que pagarle veynte e çinco fanegas de çenteno e XXX fanegas de millo al alcaide da Rocha, que se le devia quando salio de la Barrera ${ }^{64}$, unas cantidades que no le fueron abonadas en vida.

Como hemos señalado, no poseemos referencias a un feudo o señorío propio de don Álvaro, a un territorio perteneciente a su linaje y que tuviese heredades, cotos o incluso un conjunto de propiedades de más o menos reciente adquisición pero que fuese suyo. Su dominio fue A Rocha Forte y, en los años 80, A Barreira. Así lo más probable, y reforzando la posibilidad de que haya venido de fuera de Galicia con don Rodrigo de Luna, es que pertenecerse a la denominada casa del arzobispo. Su

${ }^{64} \mathrm{LR}, 2$, fol. $9 \mathrm{r}^{\circ}$. 
existencia se menciona en 1482, cuando por mandato del prelado, tal y como se recoge en el Libro de la Recabdança, se ordena que dyn et paguen por otra nomina del dicho señor arçobispo, fecha a veynte dias del dicho mes de jullio del dicho año de ochenta y dos, a los cavalleros e fidalgos e escuderos de casa del dicho señor arçobispo en ella contenidos, trinta e dos mill quinientos maravedis ${ }^{65}$.

Serían un grupo de vasallos, milites, asociados a la función militar, tanto caballeros como escuderos y, por supuesto, hidalgos, integrados en la red de solidaridades y vínculos personales en torno al arzobispo compostelano, en este caso don Alonso de Fonseca II $^{66}$. Milites que recibían un pago por el propio arzobispo: 40.350 maravedíes en 1481 y 32.500 en $1482^{67}$.

Tal hipótesis explicaría la falta de documentación y referencias de quien parece ser un noble, o cuando menos de la baja nobleza: llegaría de fuera, al servicio de don Rodrigo de Luna; se integraría en la casa del arzobispo de Santiago, de ahí su fidelidad para con tres prelados -don Rodrigo, don Alonso de Fonseca I y don Alonso de Fonseca II-, así como la confianza de la que disfruta como tenente de dos de las principales fortalezas del reino de Galicia, A Rocha y A Barreira; y permanecería en ellas casi hasta el fin de sus días cuando, acuciado por la enfermedad, sería liberado de sus obligaciones.

De modo más o menos coetáneo con la derrota de Altamira, creemos poder añadir a este episodio otro con toda probabilidad mucho más doloroso para don Álvaro. Sin conocer el momento exacto en el que ocurre el fallecimiento, es muy posible que don Álvaro haya sobrevivido a su hijo, Gil Rodrígues Varela. La única referencia que poseemos a un hijo varón del tenente de A Rocha es la de Gil Rodrígues, desde que en 7 de noviembre de 1471 don Álvaro tomarse posesión de las propiedades de Palavea en nombre del su vástago ${ }^{68}$, siendo este aún menor.

Dos ha sido los hijos de don Álvaro, Gil Rodrígues y Catalina Sánchez, ambos probablemente de su matrimonio con doña María González. Gil Rodrígues es, sin duda, hijo de este matrimonio; en el caso de Catalina no podemos hacer más que conjeturas. Es mencionada por Álvaro en su testamento, pero sin referencia alguna a su madre. Lo que nos conduce a situarla en el primer matri-

${ }^{65} \mathrm{LR}, 1$, fol. $34 \mathrm{v}^{\circ}$.

66 En palabras de Vázquez Bertomeu "un grupo indeterminado de caballeros forma la denominada «casa» arzobispal; no puede determinarse claramente su función militar aunque tampoco puede descartarse". Vazquez Bertomeu, Mercedes, La hacienda, cit., p. 64.

${ }^{67} \mathrm{LR}, 1$, fol. $34 \mathrm{r}^{\mathrm{o}}-\mathrm{v}^{\mathrm{o}}$.

$68 \mathrm{AD}$, doc. 6. ACS, S 18/40, fol. $1 \mathrm{r}^{\circ}$. 
monio es el hecho de que no aparece en el testamento de Inés García, segunda mujer del tenente de A Rocha, en el cual sí aparecen mencionados otros hijos de ella, como Justina García, hija de doña Inés y su primer marido, Juan Castellano. Dicha omisión seguramente no ocurriría si Catalina fuese biológicamente su hija ${ }^{69}$.

Sea como fuere, a Catalina Sánchez - que le había dado además una nieta, Beliça-su padre, don Álvaro, le deja diversas propiedades, como los cotos de Miño y Calvos, o la tierra de Bendaña ${ }^{70}$. Pero cuando Álvaro hace testamento, en 1489, la referencia a su hijo, Gil Rodrígues, es simplemente tangencial: el teniente de A Rocha establece su propia sepultura en una capilla de San Paio de Antealtares y que los capellanes sean siempre obligados de rogar a Nuestro Señor por las animas de aquellos cuyo siempre fue lo ya mandado e dispuesto de min e de mi fijo Gil Rodrigues Barela, espeçialmente ${ }^{71}$.

Además, la donación realizada a un hijo de Rui de Santa Aia, del cual Álvaro estaba a cargo, es hecha por descargar o anima de mi fijo e de su madre, que santa gloria aya ${ }^{72}$.

En este momento, la nobleza bajomedieval regula la transmisión de propiedades y patrimonio por medio del mayorazgo y el favorecimiento de la primogenitura y masculinidad, ya desde la formulación de las Partidas de Alfonso X; una mutación en las estructuras familiares que implica un cambio equivalente en la sucesión de los patrimonios $^{73}$. La transmisión de los bienes familiares y linajísticos en el primogénito resulta una estructura característica y constante de la nobleza del bajo medievo en Galicia, con un conjunto determinado y rígido de propiedades trasmitidas a dicho primogénito $^{74}$. Esta transmisión se convierte en garante de la transmisión unitaria e íntegra del

69 Meu primer marido, que fuy Juan Castellano, que Deus aja, regidor que fuy da dita çibdad de Santiago, e Justina Garçia, nosa filla. AD, doc. 13. ACS, IG 425, fols. $280 v^{\circ}$. Este primer matrimonio había tenido lugar ya en los años 50 de la centuria, puesto que el burgués Pedro Leiteiro, en su testamento, de 1451, realiza una manda a Juan Castellano como jurado de Santiago [...] por todo tempo de vosa vida et de sua moller Ynes Garçia. ACS, S 18/35.

70 AD, doc. 12. ACS, LD 5/1.

71 AD, doc. 12. ACS, LD 5/1.

72 AD, doc. 12. ACS, LD 5/1, fol. $2 \mathrm{v}^{\circ}$.

73 Una idea que ya apunta Jose Matosso para el ámbito galaico-portugués. "Co estreitamento das relacións de parentesco estase tamén a decantar un sentimento máis exclusivista da soliedariedade do grupo, acumulando na liña privilexiada o groso dos recursos". Matosso, J., Identificação de um pais: ensaio sobre as origens de Portugal. 1096-1325, Lisboa, vol. I, p. 80 y Paredes Mirás, Mª do Pilar, Mentalidade nobiliaria e nobreza galega. Ideal e realidade na Baixa Idade Media, A Coruña, 2002, p. 135.

74 García Oro, José, Galicia en los siglos XIV y XV, t. I, Pontevedra, 1987, p. 279. Acerca del triunfo de la masculinidad en las estructuras parentales vid. Pallares Méndez, M. ${ }^{a}$ Carmen, "Las mujeres", cit., pp. 363-364. 
patrimonio familiar ${ }^{75}$, evitando los repartos hereditarios altomedievales que tendían a una disminución progresiva de la propia base patrimonial del grupo familiar ${ }^{76}$.

Pero en el caso de los Sánchez de Ávila compostelanos la documentación nos muestra una situación con matices. El heredero universal y único de Álvaro, salvando las disposiciones y donaciones recogidas en su testamento, fue el bachiller Pedro de Almansa, justicia y alcalde mayor de la ciudad de Compostela. No hay una voluntad mayor por mantener las propiedades unidas ${ }^{77}$ o por trascender a su memoria de alguna manera, en un sentido linajístico; y ni siquiera hay una referencia destacable a su hija. La explicación a creemos clara: Catalina Sánchez era a su única hija, e Isabel Sánchez, beliça, aún niña, su única nieta. Gil Rodrígues Varela había fallecido ya, y don Álvaro se enfrentaba a su muerte sin ningún hijo varón.

Considerando, por otra parte, la presencia de Catalina Sánchez en el testamento de don Álvaro, podemos realizar algunas precisiones. En la sucesión de las familias nobiliarias, desde el siglo XIV, la dote era el contingente principal de propiedades o bienes que recibían las hijas, no siendo frecuente que accediesen al mayorazgo, salvo en el caso de que no hubiese herederos masculinos ${ }^{78}$. Éste es uno de tales casos -o por lo menos eso deducimos del testamento de don Álvaro-. Sin hijo varón, Álvaro Sánchez deja a su hija, Catalina Sánchez, lo que debía de ser un importante conjunto de propiedades, la terra de Vendanna ${ }^{79}$; pero existe un matiz importante: no constituye tal conjunto el núcleo de señorío alguno o de propiedad, sino que se trataba de una concesión puntual. En el mismo testamento solicita al arzobispo que permita a Catalina poseer esa tierra de Bendaña por lo menos por tiempo de su vida, conosçiendo mi voluntad, e avyendo acatamento a ella e a los serviçios que he fecho a la santa ygllisia de Santiago e a su reverendisyma senno$\mathrm{ria}^{80}$. No se trata, pues, de un mayorazgo hereditario y transmisible a los descendientes. De hecho ni siquiera su único descendiente, Catalina, es su heredera universal, sino que lo es su amigo Pedro de Almansa, justicia da ciudad de Santiago ${ }^{81}$.

75 Fernández Conde, Francisco J., La España de los siglos XIII al XV. Transformaciones del feudalismo tardío, Madrid, 2004, p. 82.

76 Pallares, María do Carmen; Portela, Ermelindo, "Aristocracia", cit., p. 840.

77 Lo que sí aparece en otros casos, como el testamento de Pedro Arias de Aldao, que ya en 1374 afirma que he miña voontade que toda a miña fazenda quede junta, porque sempre aja memoria de miñas casas e da miña gente fidalga que delas ven. García Oro, José, Galicia, cit., p. 280.

78 Beceiro Pita, Isabel; Córdoba da Llave, Ricardo, Parentesco, cit., p. 243.

79 AD, doc. 12.

$80 \mathrm{AD}$, doc. 12

${ }^{81}$ Iten fago e establesco para mi vniversal heredero en todos mis byenes muebeles e rayzes e semoventes mis mandas e legados complidas al honrrado sennor bachiller Pedro d'Almança, justiçia e alcalde mayor da çibdad e arçobispado de Santiago. AD, doc. 12. 
La muerte de Gil Rodrígues se ve confirmada por una imprecisa pero significativa nota marginal, ya del siglo XVI, en el Tumbo III de Tenencias, junto a la referencia a los cotos de Calvos y Santiso que poseía don Álvaro Sánchez: Este caballero murió sin hijos aviéndo estado casado con hija del Mariscal Suero Gómez de Sotomayor ${ }^{82}$. Ciertamente falleció sin hijos, aunque sí con una hija, Catalina Sánchez; tampoco resulta correcta la afirmación acerca de la hija del mariscal Suero Gómez, sin duda una confusión por los nombres. La hija de Suero Gómez de Soutomaior fue Inés de Mendoza y Soutomaior ${ }^{83}$, no Inés García que aparece como mujer de don Álvaro; una Inés García que, además, en su testamento en 12 de junio de 1493, deja dispuesta una oración por la alma de Gomez Garcia, meu padre ${ }^{84}$. Inés de Mendoza y Soutomaior estuvo casada con García de Caamaño, probablemente el mismo que, por tiempo de seis meses, ocupó la tenencia de a Rocha Forte en el año 1459. De ahí toda la confusión de personajes.

Los últimos años de vida de don Álvaro no debieron de ser muy apacibles, ya no sólo por la muerte de su hijo o por las heridas que batallas pasadas le hubiese podido dejar como recuerdo, sino tampoco en el plano marital. El tenente de A Rocha Forte debió de disfrutar de la compañía de su nieta, Isabel Sánchez de Ávila, de la que podemos casi palpar el cariño que su abuelo le profesa en su testamento, refiriéndose a ella con el apelativo que le tenía, beliça, suponemos que beleza. En el testamento simplemente se refiere a ella por tal apodo, y la deja bajo la tutoría de su amigo Francisco de Treviño; tiempo después, encontramos al Cabildo compostelano entregando la Isabel Sánchez de Ávila y a su marido, Álvaro Núñez, los legados que le hizo Francisco, que ya había fallecido ${ }^{85}$.

La paz no debió de ser frecuente en la vejez de Álvaro Sánchez. Su segunda esposa, Inés, cuando hace testamento el 12 de junio de 1493, no parece guardar muy buen recuerdo del matrimonio con Álvaro; de hecho no parece querer tener recuerdo alguno. No hay referencia a los hijos que tenía el tenente de A Rocha, pero tampoco mayor referencia a él mismo, más allá de una misa cantada en el monasterio de San Paio, donde estaba enterrado, y con una simple frase: que os monxes do dito monesterio sejan obligados de dizir eno dito monesterio vna misa cantada por la alma do dito Alvaro Sanches meu marido, e vaan con responso e agoa vieyta sobre sua sepultura ${ }^{86}$. Ciertamente, Inés se refiere a sí misma, en la intitulación

\footnotetext{
82 ACS, CF 16, fol. VIIIv ${ }^{\circ}$.

83 Hija de Suero Gómez de Soutomaior y Leonor Vázquez.

84 AD, doc. 13. ACS, IG 425, fols. 281r ${ }^{\circ}$.

85 AD, doc. 18. ACS, IG 479, fol. $72 \mathrm{r}^{\circ}$.

86 AD, doc. 13. ACS, IG 425, fols. $281 \mathrm{r}^{\circ}$.
} 
del documento, como Ynes Garcia, muller que fuy de Alvaro Sanches de Avila, regidor que fuy da çibdade de Santiago ${ }^{87}$, pero en tales referencias termina la presencia de don Álvaro en el testamento de su esposa.

Tampoco él debió de guardarle demasiado cariño. En su testamento Álvaro despacha las menciones a Inés con un apartado lleno de frialdad, incluso refiriéndose a la casa donde ambos residían, y devolviéndole todo lo muevle que ella declarare por su juramento que consiguio por mi travaxo quando conmigo caso; et queriendo vebir en esta mi casa en que yo e ella al presente bebimos que lo pueda faser en toda su vida, contanto que al tiempo de su muerte quede libre de mi herdero. Et se esto non quisyere e demandare a meytad do prefecto da dicha casa, como quera que entre mi e ella esta un contrato que paso por ante Alvaro de Casteenda, notario, que nos avemos de demandar prefecto vno al otro de los perfectos que fezieremos, asy en su fasienda conmo na mia, que esten con ella a justiçia e le satisfagan aquello si fuere jusgado. Et a casa quede libre a mi herdero syn que ella en ella biba algund tiempo ${ }^{88}$. Pero, especialmente elocuente de la relación es la frase con la que termina la manda: Et en satisfaçion de algund travajo, se conmigo lo llevo, le mando a meytad da renta do Ejo ${ }^{89}$.

Como veremos más adelante, la política matrimonial de don Álvaro Sánchez respondió a la necesidad de asentar un estatus social por medio de la obtención de recursos económicos procedentes de las familias de la burguesía y la oligarquía urbana compostelana. Unos recursos que son empleados para afianzar su posición por medio de la adquisición de cesiones o aforamientos de propiedades, como diversos cotos. Si a eso unimos la que debería de ser una personalidad fuerte, enérgica y brusca -por lo menos en función de los diversos episodios narrados en el Tabera-Fonseca- resulta comprensible que las relaciones con su señora fuesen, cuando menos, tirantes.

Así en 1489, don Álvaro, ya enfermo desde hacía algún tiempo, expira. En su testamento dispone que mando que mis complidores asenten de los aniversarios en mi fazienda en la yglisia de Santiago; et el vno se diga en dia de los Innoçentes de las ochavas de Navidad, e el otro que se diga a quinse dias del mes de junio $^{90}$, pero los aniversarios fundados en la iglesia compostelana tienen lugar los días 28 de abril y 6 de septiembre, de los cuales queda testigo documental en el Tumbo de Aniversarios, estableciendo que in ista XXVIII die mensis aprilis fiat

$87 \mathrm{AD}$, doc. 13. ACS, IG 425, fols. $280 \mathrm{r}^{\circ}$.

88 AD, doc. 12. ACS, LD 5/1, fol. $1 v^{\circ}$.

89 AD, doc. 12. ACS, LD 5/1, fol. $1 v^{\circ}$.

90 AD, doc. 12. ACS, LD 5/1, fol. $2 \mathrm{r}^{\circ}$. 
anniversarium pro anima honorati viri domini Alvari Santii de Avila, quondam tenetis in omagio Rumpem Fortem per reverendisimo domno archiepiscopo compostelano $^{91}$ y otro in ista sexta die mensis septembris ${ }^{92}$, aunque, ciertamente, no es garantía alguna de que el fallecimiento se hubiese producido en alguna de ambas fechas. Los aniversarios son fundados por uno de sus compridores y que debía de ser un buen amigo, Francisco de Treviño, también regidor compostelano y fallecido antes de $1511^{93}$.

Lo que sí es seguro es el año del fallecimiento de Álvaro, ya que en el Libro de Recabdança correspondiente a los años 1487-1491 el mayordomo de la tierra de Bendaña recebe el servicio que los vecinos rendían al arzobispo compostelano desque fallesçió el alcaide de la Rocha, sendo tales servicios de los años LXXXIX, XC, $X C I^{94}$. Es decir, 1489, año de su testamento.

Tras su muerte, don Álvaro, como había expresado en su testamento, fue enterrado en la iglesia del monasterio de San Paio de Antealtares, junto a la capilla de Santa María, a la que tenía devoción, lugar donde aún hoy debe descansar, bajo las diversas obras modernas en el templo.

Su recuerdo histórico permaneció en las mandas testamentarias que dejó, puesto que algunas de ellas generaron ciertas controversias de las que se da cuenta en los tumbos compostelanos a la altura del siglo XVI. En una reunión capitular de 1511 se refieren las capellanías que había ordenado fundar el alcalde da Roch $a^{95}$. Además, parece que durante bastante tiempo permanecieron las huellas de los descendientes de don Álvaro. En los inicios del siglo XVI, hacia 1512, se desarrolla en la iglesia compostelana un pleito por las propiedades que había poseído don Álvaro, pleito en el cual el Cabildo se enfrenta a Álvaro Núñez y su esposa, Isabel Sánchez de Ávila, beliça ${ }^{96}$. No sabemos si Isabel tuvo descendencia y mantuvo el linaje -ya desvirtuado en cuanto a las concepciones medievales

91 AD, doc. 15. ACS, CF 13, fol. 16r ${ }^{\circ}$.

92 AD, doc. 16. ACS, CF 12, fol. $7 v^{\circ}$ e ACS, CF 13, fol. $33 v^{\circ}$.

${ }^{93}$ En un acta capitular de 16 de octubre de 1511 se hace referencia a una serie de miembros del Cabido como herederos de Francisco de Treviño. ACS, IG 478, fol. $294 r^{\circ}$. Francisco debía de mantener una buena amistad con Álvaro Sánchez, ya que éste lo nombra tutor de su nieta, Beliça: al qual conmo a mi buen e espeçial amigo ge la encargo, non mas ni menos que sy fuese fija propia, mia o suya. AD, doc. 12. ACS, LD 5/1, fol. $2 \mathrm{v}^{\circ}-3 \mathrm{r}^{\circ}$.

${ }^{94}$ LR, 2, fol. $8 \mathrm{r}^{\circ}$.

95 ACS, IG 478, fol. $294 \mathrm{r}^{\circ}$.

96 ACS, IG 478, fol. $393 v^{\circ}$. En este caso concreto aparece Ysabel Sanchez de Avila, pero en muchas otras referencias aparece como tal, con los apellidos de la familia; por ejemplo ACS, IG 479, fol. $70 v^{\circ}$ ou ACS, IG 479, fol. $72 \mathrm{r}^{\circ}$. 
del término-; de lo que sí podemos estar seguros es de que el matrimonio fue provechoso, ya que Álvaro Núñez era secretario de la Real Audiencia a comienzos del siglo XVI ${ }^{97}$. Mucho tiempo después aún podemos localizar antropónimos relacionados con Álvaro, como una Catalina Sánchez de Ávila referida en una escritura de $1678^{98}$, que ciertamente podría no tener relación directa con el caballero, pero de la que nos llama profundamente la atención tanto el apellido como el nombre, coincidente con el de la hija de don Álvaro, pudiendo tratarse de una descendente.

Como vemos, una completa, azarosa y apasionante existencia, a través de la cuál es posible seguir y observar la evolución nobiliaria en Galicia bajomedieval, y de la que llegados a este punto es menester hacer un compendio. Aparece Álvaro Sánchez en las fuentes hacia mediados de siglo, cuando, en 1455, y todavía sin haberse casado, toma el foro de San Pedro de Viños, San Martiño de Calvos y Santiso de Calvos, siendo ya alcaide y tenente de Rocha Forte. A partir de aquí, y cabalgando junto a su hermano, Pedro Sánchez, don Álvaro se constata como hombre de confianza de los arzobispos compostelanos, especialmente de don Alonso de Fonseca II, en los críticos años 60 de la centuria. Don Álvaro, a la frente de A Rocha, defiende los derechos del arzobispado a capa y espada.

Pronto se casa con la hija de un miembro de la burguesía urbana compostelana, María González, con la que tendrá un hijo, Gil Rodrígues Varela, y una hija, Catalina Sánchez. Hacia 1466 participa en la defensa de su amado castillo, el que había tenido que entregar por tiempo de algunos meses en 1459 y que después había recuperado, aquel por el que había hecho nuevo pleito y homenaje a don Alonso de Fonseca II: A Rocha Forte. Pero A Rocha es asediada y destruida, quedando sólo piedra, muros y cenizas.

Poco después, y en tiempo inferior a un año, entre 1471 y 1472 su matrimonio se deshace, y don Álvaro toma ligero nueva esposa, Inés García, también integrada en la oligarquía urbana y que le aportará importantes recursos económicos.

La edad iba ya haciendo mella y, en ese mismo momento, en el año 1471, recibe la mayor derrota militar de su vida: la batalla de Altamira. Aquí resiste en defensa del arzobispo, bravo como los héroes de las canciones de caballería, como los Lanzarote, Galahad o Perceval, pero termina preso y herido, cumpliendo su cautiverio en el castillo de los Andrade, en Pontedeume. Las heridas debieron de ser considerables, pero don Álvaro no se alejó de la función militar sino que, vasallo

97 Alvaro Nunnez, secretario de la avdiençia real. AD, doc. 17. ACS, IG 479, fol. $69 \mathrm{v}^{\circ}$.

98 ACS, IG 705/5. 
de su señor el arzobispo de Santiago, aceptó un nuevo encargo: la tenencia de la fortaleza de A Barreira, de la que toma posesión antes de 1481 y donde permanece buen parte de la década.

A finales de los años 80 su hija Catalina -ya viuda de Juan de Presedo- lo había hecho abuelo, con una nieta llamada Isabel Sánchez, a la que él llamaba cariñosamente beliça. Pero el padre había sobrevivido al hijo: Gil Rodrígues Varela había fallecido hacía algún tiempo, y don Álvaro, enfermo, se aproximaba ya a su muerte. En 1489 dispone su testamento dejando todo arreglado: herederos, compridores, entierro, sepultura... Sin olvidarse de los miembros de su casa, sus criados, realizando diversas y múltiples mandas para ellos.

Poco tiempo después fallece. Sus deseos y disposiciones son cumplidos y se fundan dos aniversarios en la Catedral de Santiago que recordarían la memoria del más audaz miles que defendió el pendón del arzobispado compostelano y del más fiel y autoritario vasallo de la prelatura en el siglo XV; un cumplimiento de sus mandas que traería consigo aún varios pleitos con el Cabildo en los inicios del siglo XVI.

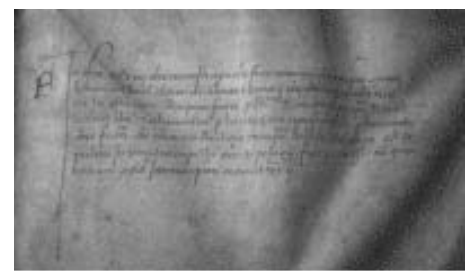

Fundación del aniversario de don Álvaro Sánchez de Ávila en la iglesia compostelana. ACS, CF 13, fol. $16 r^{\circ}$.

No tarda mucho en seguirlo su segunda esposa, Inés García, que no guardaba muy buen recuerdo de él, pero que aún así en su testamento, en 1493, pide una oración por su alma.

Llega de esta forma a su fin la existencia de uno de los últimos nobles medievales de Galicia, fuese o no gallego, forjado a base de correrías, excesos y fechorías, pero también a fuerza de batallas, acero y espada. Un noble que conjugaba, en su figura, estructuras medievales con comportamientos y recursos ya propios de la transición a la modernidad. Un noble definido, sin duda alguna, por un cargo concreto: el de tenente de A Rocha Forte. 


\section{LA TENENCIA DE FORTALEZAS EN EL ARZOBISPADO DE SANTIAGO EN EL SIGLO XV. ÁLVARO SÁNCHEZ DE ÁVILA, TENENTE DE ROCHA FORTE: EL GUERRERO VALEDOR DEL ARZOBISPADO COMPOSTE- LANO}

El papel que don Álvaro Sánchez de Ávila juega en el complicado tablero de ajedrez que es la Galicia de la segunda mitad del siglo XV, como alfil del arzobispo de Santiago, se comprende sobre la base de su más destacado cargo: tenente del castillo de A Rocha Forte. A Rocha constituye la fortaleza de mayor potencia y resistencia de Galicia, disfrutando de un completo sistema defensivo y de recios muros, organizados en tres cercas, según nos informan las testigos del Tabera-Fonseca, foso y todos los adelantos arquitectónicos del momento ${ }^{99}$. Dentro de él, siempre preparado, esperaría un contingente armado dispuesto a seguir las órdenes del prelado en boca de su casteleiro Álvaro Sánchez. Por lo menos desde el año 1455 don Álvaro es tenente de A Rocha Forte, manteniéndose como tal hasta la destrucción del castillo, hacia 1466; un cargo que desempeña como un verdadero señor militar.

En el siglo XV el arzobispado compostelano necesitaba, para asegurar la posesión de su patrimonio territorial y su poder político, una completa infraestructura militar que cobijase, además, a una numerosa milicia. En el centro de tal sistema se encuentra, como núcleo fundamental, el castillo ${ }^{100}$ en su concepción más objetiva. Desde el pleno medievo la nobleza hizo de las fortalezas el símbolo de su poder jurisdiccional y de la calidad señorial ${ }^{101}$.

A estas alturas del siglo XV la prelatura compostelana contaba con multitud de enclaves fortificados y fortalezas con las que garantizar la defensa de su señorío y territorio, y tratar de mantener el orden y autoridad: disponía "además de la Catedral fortificada, de la Torre nueva de los palacios viejos y de la Torre de la Plaza; y fuera de la población, de las Torres de Oeste, Pontevedra, Caldas de Reyes, Noya y Muros $^{102}$, y de los Castillos de Montes, Loveira, Rodeiro, Barreira, Rocha Blanca, Rocha Fuerte, Mesía y Cira, sin contar los de Benquerencia y Borrajeiros, hipotecados en $1456 " 103$.

99 Acerca del sistema constructivo de Rocha Forte y el ámbito militar vid. Sánchez Sánchez, Xosé M., "La fortaleza de Rocha Forte. Un castillo concéntrico en las corrientes constructivas europeas del siglo XIV", Compostellanum, vol. LII, n 3-4 (2007), pp. 603-631.

100 Vazquez Bertomeu, Mercedes, La hacienda, cit., p. 61.

101 Quintanilla Raso, María Concepción, "La tenencia de fortalezas en Castilla durante la baja Edad Media", En la España medieval, n 5, Madrid, 1986, p. 862.

102 Villas fortificadas o con fortalezas.

103 Portela Pazos, Salustiano, Galicia, cit., p. 22. 
El concepto de tenencia se fundamenta en el poder ejercido sobre un determinado espacio u objeto pero no basado en el derecho absoluto sobre el mismo, sino en la cesión del derecho sobre esa posesión y en el gozo por el nuevo titular de ese derecho absoluto ${ }^{104}$. La tenencia es un recurso originariamente regio de origen altomedieval pero que se fija y consolida como institución en la segunda mitad del siglo XIII y principios del XIV ${ }^{105}$, con el monarca concediendo la tenencia de un determinado espacio, ya fuese castillo, población, comarca, etc. a un vasallo, que pasaba a ostentar sobre él el poder público de modo temporal y reversible ${ }^{106}$. Tal práctica de la monarquía se difundió de tal modo que comenzaron a ponerla en funcionamiento los grandes señores feudales, concediendo ciertos ámbitos en tenencia a sus vasallos. Fue la necesidad de mantenimiento de las fortalezas y de sostener la actividad de defensa de los múltiples enclaves la que propició la aparición de esta institución medieval, que reglamenta la relación establecida entre ambas partes contrayentes ${ }^{107}$.

Una fórmula, la de la tenencia, que se revela como fundamental a lo largo de la historia de la sede compostelana, ya no sólo en el caso de A Rocha, sino de muchas otras fortalezas diseminadas por buen parte del territorio gallego medieval; desde el castellum Honesti del siglo XII hasta multitud de enclaves del XV, como A Rocha Blanca, Mesía, Xallas, A Barreira, Castrizán o A Insua. La centuria del cuatrocientos en la iglesia compostelana comienza con un recién inaugurado arzobispado de don Lope de Mendoza, en 1399. Buena idea de la importancia que la posesión de las fortalezas tenía para el arzobispado nos la ofrecen los diversos pleitos y homenajes que se llevaron a cabo casi inmediatamente después de la toma de posesión del nuevo arzobispo. En 21 de abril de 1402 Arias Vázquez de Bahamonde hace homenaje por el castillo de Insua ${ }^{108}$, en 22 de abril Lopo González de Baar hace lo propio por A Barreira $^{109}$ y en 14 de mayo Rui Sánchez de Moscoso lo hace por Xallas ${ }^{110}$.

104 Definición de José M. Calderón Ortega, en Calderón Ortega, José Manuel, Álvaro de Luna: riqueza y poder en la Castilla del siglo XV, Madrid, 1998, p. 124. Recopilación bibliográfica acerca de la tenencia de fortalezas en la Edad Media en Castrillo Lamas, María de la Concepción, "Monarquía”, cit., p. 95, nt. 1.

105 Ibidem, p. 111.

106 Las primeiras normativas acerca de las fortalezas proceden ya de los siglos XII y XIII, con apartados en los fueros recogiendo referencias al cuidado de murallas, torres y castillos o al nombramiento de alcaides. En el siglo XIII las Partidas de Alfonso X suponen un nuevo paso en tal reglamentación, especificando desde la concesión de un enclave a un alcaide hasta sus funciones. Ibidem, p. 97.

107 Quintanilla Raso, María Concepción, "La tenencia", cit., p. 862.

108 ACS, IG 703/31. Ref. Novás Pérez, M. ${ }^{a}$ Elena, Catálogo de la Colección de Tomos de Varia (Primera Serie) del Archivo-Biblioteca de la Catedral de Santiago, Santiago de Compostela, 2006, inédito.

109 ACS, IG 703/15. Ref. Ibidem.

110 ACS, IG 703/8. Ref. Ibidem. 
La posesión por delegación de tales enclaves no es solamente importante para el titular del señorío, el arzobispado, sino también a la inversa. Tal posesión y disposición de bienes y, especialmente, de jurisdicciones pertenecientes al poder episcopal o monástico, es uno de los elementos sobre los cales se sustenta la primacía de la nobleza gallega a lo largo de la baja Edad Media y, especialmente, en el siglo $\mathrm{XV}^{111}$. Como veremos, este esquema se ajusta perfectamente al caso de Álvaro Sánchez, noble, de mayor o menor origen, que asienta las bases de su preeminencia sobre su calidad de tenente del fuerte de Rocha Forte.

La prelatura compostelana, tradicionalmente, sufrió muchos problemas para desarrollar un control efectivo de su territorio e impedir que sus fortalezas cayesen en manos nobiliarias y favoreciesen la instalación de determinados linajes en su señorío, o que sucumbiesen al control realengo. Así pues, los arzobispos de Santiago buscaban la cesión de sus fortalezas a nobles y caballeros que por medio del pleito y homenaje pasaban a ser vasallos, "en general, prestimoniarios cuya relación suponía en una primera época un intercambio, en el marco de las relaciones feudovasalláticas, beneficioso para ambas partes"112. Con el devenir del medievo la nobleza fue la clase beneficiaria de la cesión de fortalezas y castillos en los reinos de Castilla y León, tanto a nivel regio como eclesiástico; se repite aquí el esquema de un noble que, con un castillo concedido, prácticamente lo patrimonializa y establece en torno a él su radio de acción.

Por otra parte el ejercicio de la justicia o el de la defensa militar, como en el caso de la tenencia de fortalezas, constituye desde la alta Edad Media un coto de poder que fueron asumiendo las clases dirigentes ${ }^{113}$, en algunos momentos sometidos a la autoridad regia, y en otros, como éste, al poder de un señor de verdadera entidad como el arzobispado. Un terreno que se integraría en el organigrama desarrollado por los prelados del siglo XV para controlar un territorio levantisco y con múltiples conflictos a lo largo de toda la centuria ${ }^{114}$.

111 Un aspecto más acentuado en Galicia que en el resto del reino castellano. Olivera Serrano, César, "La Galicia de Vasco de Aponte: los pleitos del arzobispo Tabera contra los linajes de la Tierra de Santiago", En la España medieval, n 22, 1998, p. 286.

112 González Vázquez, Marta, El arzobispo de Santiago: una instancia de poder en la Edad Media (1150-1400), A Coruña, 1996, p. 192.

113 Baliñas Pérez, Carlos, "O poder militar como elemento de afirmación social: o caso da nobreza altomedieval galega", en Vázquez Varela, J. M. et al., A guerra en Galicia; o rural e o urbano na historia de Galicia, Santiago de Compostela, 1996, pp. 66-67.

114 Vázquez Bertomeu, Mercedes, "La iglesia de Santiago hacia 1500: el Libro I de Subsidio", Compostellanum vol. LXVII (2002), pp. 446-447. 
En el caso que nos ocupa la fidelidad de don Álvaro, tomado como vasallo en el sentido más feudal del término, está más allá de toda duda en lo que respecta a su señor, el arzobispo de Santiago, manteniendo durante buen parte del siglo XV ese cargo de la tenencia de A Rocha Forte, básico en la estrategia militar y política arzobispal -además de mantener la confianza de los sucesivos prelados don Rodrigo de Luna, don Alonso de Fonseca I y don Alonso de Fonseca II ${ }^{115}$, tanto en la posesión del enclave como en el disfrute de rentas y privilegios-.

Es aquí donde se inserta la consideración que ya hemos introducido de don Álvaro como integrado en la casa del arzobispo compostelano. La relación establecida, desde luego, encaja a la perfección con la consideración tradicional de la casa nobiliaria y con la significación de las relaciones feudovasalláticas pasadas por el tamiz de la baja Edad Media -además del hecho, ya señalado, de la indefinición del dominio, señorío o, incluso, linaje de Álvaro Sánchez-.

No es este un caso extraño en Galicia del siglo XV ya que, en el contexto de las revueltas irmandiñas, de la agitación social y de la convulsión política, muchos nobles o hidalgos, pertenecientes a la media o baja nobleza, vincularon su propio destino al devenir de la mitra compostelana, especialmente en el último tercio de la centuria $^{116}$.

Considerando el terreno más práctico, el dominio y posesión de A Rocha resulta básica para los prelados compostelanos desde el punto de vista estratégico, ya incluso desde el momento de su construcción, con don Juan Arias hacia mediados del siglo XIII ${ }^{117}$. A partir de aquí el castillo, tomado como residencia y refugio de los arzobispos, cobra una importancia fundamental a lo largo de toda la baja Edad Media; tanto en la revuelta compostelana con Berenguel de Landoira, en el primer cuarto del siglo XIV, como en los diversos levantamientos del $\mathrm{XV}^{118}$. Es por ello por lo que diversos prelados realizan mejoras y refuerzos en el castillo -especialmente don Berenguel- adaptándolo a los nuevos tiempos constructivos $^{119}$.

115 Acerca de la figura de Alonso de Fonseca II como señor feudal vid. Pallares, $\mathrm{M}^{\mathrm{a}}$ Carmen; Portela, Ermelindo, "Reis, bispos e burgueses", cap. de Portela, Ermelindo (coord.), Historia de la ciudad de Santiago de Compostela, Santiago de Compostela, 2003, p. 166.

116 Es el caso, por ejemplo, de los Valladares, en el sur de Galicia. Olivera Serrano, César, El ocaso de las fortalezas compostelanas. Visitas y tasaciones (1535-1547), Santiago de Compostela, 2000, p. 37.

117 Portela, Ermelindo; Pallares, Mª Carmen; Sánchez, Xosé M., Rocha Forte, cit., p. 61.

118 Ibidem, pp. 64 ss.

119 Ibidem, p. 64 e Sánchez Sánchez, Xosé M., "La fortaleza”, op. cit., p. 611-625. 


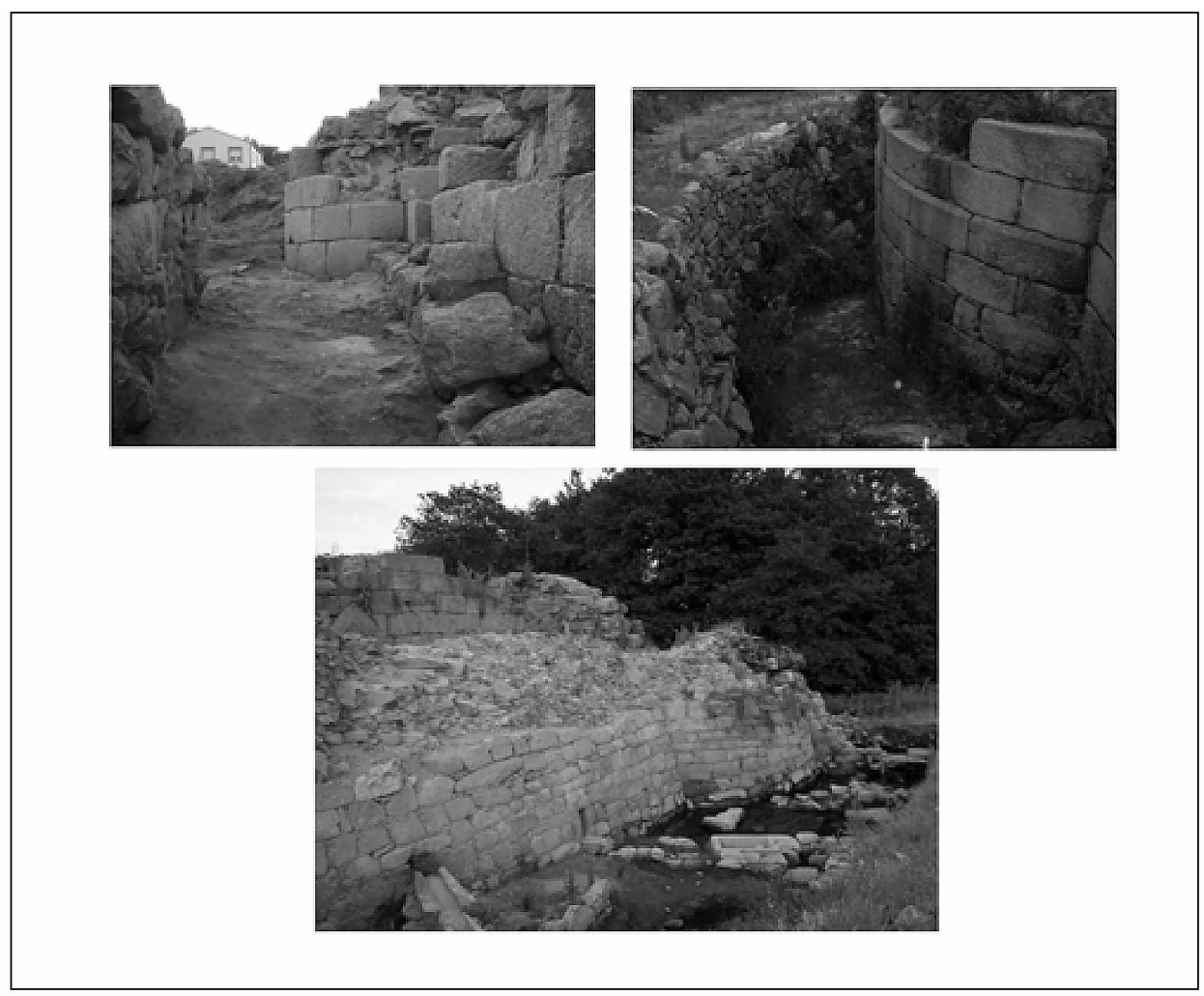

Fortaleza de Rocha Forte (Santiago de Compostela), centro de la actividad de Álvaro Sánchez de Ávila durante buena parte del siglo XV.

De esta forma, el cargo de tenente del castillo de A Rocha Forte pasa a ser uno de los más destacados desde el punto de vista militar en relación con la prelatura compostelana y con la defensa más directa de la Iglesia de Santiago. El tenente tenía que ser un miles, acostumbrado a la batalla, que no le temblarse a mano a la hora de imponer un más que severo orden, y una persona completamente fiel y afecta al arzobispado, dada la responsabilidad que ostentaría.

Y parece que todas estas características las reunía Álvaro Sánchez de Ávila, el principal tenente del castillo en el siglo XV. Tras los episodios recogidos por Vasco de Aponte, recogiendo su participación en la batalla de Altamira, o las referencias del Tabera-Fonseca, rememorando las correrías por la tierra de Santiago junto a su hermano y su compañía, resulta evidente el cumplimiento de su papel militar; era él quien controlaba el flujo de impuestos hacia Compostela y el tráfico de mercancías por el camino de Padrón, vigilado por A Rocha como punto de cobro de tasas. 
En 1 de febrero de 1438 don Lope de Mendoza nombra alcaldes de Pontevedra a Alfonso Vázquez de Castelblanco y Rui Gómez de Lugo por tiempo de ese año; en 1477, ya en la época de Alonso de Fonseca II, tras haber ordenado edificar la fortaleza de Castrizán junto a la villa de Redondela y frente al castillo de Soutomaior, con el fin de hacer oposición a Pedro Madruga, el prelado pone al frente del mismo a Álvaro de Várcea, perteneciente a una familia que había servido tradicionalmente a los arzobispos compostelanos desde tiempos de don Lope de Mendo$z^{120}$. Es así también como llegó don Álvaro a ser regidor de la ciudad de Santiago, por influencia y nombramiento arzobispal.

Pero, además, don Álvaro era fiel; fiel a la prelatura compostelana como institución. El cargo de tenente de A Rocha Forte es desempeñado con tres arzobispos diferentes: don Rodrigo de Luna, don Alonso de Fonseca I y don Alonso de Fonseca II. Una confianza extrema; la renovación de este compromiso en un momento de levantamientos y luchas como el de la segunda mitad del siglo XV sólo puede implicar fidelidad, una fidelidad feudal hacia un señor como es, en este caso, el arzobispo.

De hecho, cuando se produce el cambio de prelado de Alonso de Fonseca I al II, el arzobispo saliente solicita a don Álvaro que acudades et entregedes et fagades acudir et entregar esa dicha casa et fortoleza que por nos tenedes a Alonso de Fonseca II ${ }^{121}$. Esta petición tiene su importancia si consideramos que la devolución de fortalezas fue, a lo largo de toda la Edad Media peninsular, fuente de conflictos, ya fuese en los enclaves realengos o, como en este caso, en los de señorío eclesiásti$\mathrm{co}^{122}$. Mas Álvaro, buen vasallo, devuelve nominalmente la fortaleza y hace un nuevo pleito y homenaje al prelado entrante, en 25 de agosto de 1463.

En ese homenaje Álvaro afirma no sólo que ternia la dicha fortoleza et la guardaria para el dicho sennor arçobispo, et que lo acogeria en ella, sino, más acorde con el momento, que faria des la dicha fortoleza gerra el paz por su mandado e conpliria todos los otros sus mandamientos ${ }^{123}$. Se trata del reconocimiento señorial con respecto a un señor, evolución del auxilium plenomedieval. En A Rocha Álvaro Sánchez era la máxima autoridad militar, y tenía la fortaleza basteçida de armas e gente suya ${ }^{124}$.

120 Sánchez Sánchez, Xosé M., “Castrizán: a fortaleza vixiante do sur. 1477-1478/79”, Seminario de Estudios Redondeláns, $\mathrm{n}^{\circ}$ 2, Redondela, 2005, p. 74.

121 Portela, Ermelindo; Pallares, Mª Carmen; Sánchez, Xosé M., Rocha Forte, cit., ap. 5.

122 Castrillo Lamas, María de la Concepción, "Monarquía", cit., pp. 98-99.

123 Portela, Ermelindo; Pallares, Mª Carmen; Sánchez, Xosé M., Rocha Forte, cit., ap. 5.

124 Ibidem, ap. 5. 
Tal pleito y homenaje era algo común en este momento para la tenencia de un castillo, uno de los enclaves más delicados de manejar en los grandes señoríos. De hecho, en el mismo legajo que el pleito de Álvaro Sánchez por la Rocha está el pleito de Gonzalo de Figueroa por el castillo de Xallas ${ }^{125}$. En este sentido, el momento de cambio de titular en la prelatura es uno de los más difíciles de gestionar para la renovación de los homenajes, ya que en no pocas ocasiones los titulares no atendían a las peticiones del nuevo arzobispo para cumplir un requisito, el del pleito, que la institución eclesiástica consideraban fundamental e ineludible ${ }^{126}$. En el caso de las fortalezas de propiedad particular pero instaladas en la tierra de Santiago tal tenencia llegó a hacerse hereditaria; así, otro de los momentos especialmente problemáticos fue el de transmisión en herencia del enclave, ya que los herederos, en ocasiones, no deseaban hacer homenaje alguno al prelado ${ }^{127}$.

Hemos de detenernos un instante en este pleito y homenaje desde el punto de vista morfológico y simbólico, ya que en él encontramos la pervivencia de determinados elementos propios de las relaciones feudovasalláticas del feudalismo clásico plenomedieval. La forma de pleito-homenaje que aquí observamos se pone en práctica desde el siglo XIII en Castilla y es interpretada tradicionalmente como una derivación del homenaje del feudalismo clásico. Por nuestra parte, si examinamos detenidamente el pleito que Álvaro Sánchez de Ávila hace por el castillo de A Rocha en 1463 a don Alonso de Fonseca I, podemos localizar determinados elementos que derivan del hominium clásico feudovasallático ${ }^{128}$.

La importancia que la tenencia de fortalezas poseyó en la baja Edad Media, hizo que se configurarse una forma de cesión, por medio del pleito y homenaje, muy próxima a los vínculos vasalláticos plenomedievales, concibiendo el hecho de la tenencia como una concesión feudal, "un tipo de relación feudovasallática algo especial, limitada al ejercicio de este específico «beneficio de función»"129.

De hecho, como analiza para el caso castellano $\mathrm{M}^{\mathrm{a}}$ Concepción Quintanilla, el pleito-homenaje deriva de aspectos de ese hominium vasallático y, por otra parte, del placitum altomedieval, como forma nobiliaria de vinculación ${ }^{130}$. El pleito y

125 Ibidem, ap. 5.

126 González Vázquez, Marta, El arzobispo, cit., p. 194.

127 Ibidem, p. 194.

128 Quintanilla Raso, María Concepción, "La tenencia”, cit., p. 870. Castrillo Lamas, María de la Concepción, "Monarquía", cit., p. 100.

129 Quintanilla Raso, María Concepción, "La tenencia”, cit., p. 873.

130 Ibidem, p. 871. 
homenaje amplía estos sentidos, empleándose para compromisos diversos, desde matrimonios hasta la tenencia de fortalezas, pasando por alianzas políticas, de forma que pierde el sentido estricto feudovasallático.

El volo o declaración de voluntad y de aceptación del pleito y homenaje por parte del vasallo era uno de los primeros elementos observables en ese vasallaje clásico $^{131}$. Tal declaración se encuentra aquí bastante clara, pues don Álvaro dixo que el se dava por entrego y apoderado de la dicha fortoleza y casa fuerte [...]. Y prometio, conmo home fijodalgo que tenia la dicha fortoleza et la guardaria para el dicho sennor arçobispo ${ }^{132}$.

Tras tal aceptación se procedía a tomar el pleito-homenaje propiamente dicho, por medio del inmixtio manuum, es decir, la mezcla de manos entre el vasallo y el receptor del homenaje ${ }^{133}$, con un sentido de proximidad y relación entre ambos. La pervivencia de tal elemento resulta también evidente en el homenaje a Alonso de Fonseca I: Álvaro Sánchez fizo pleito et omenajen vna, dos e tres vezes segund fore e custume d'Espana con manos del sennor Fernando de Fonseca, cavallero et home fijodalgo, que del lo reçebio vna, dos e tres vezes ${ }^{134}$; y nuevamente podemos observarlo en el pleito y homenaje que hace por la fortaleza de Rocha Forte la Alonso de Fonseca II en 1464: Alvaro Sanches fiso pleito e omenajen en forma devida al dicho sennor arçobispo de Santiago, en manos del bachiller Juan Vela ${ }^{135}$. De hecho muchos de los pleitos y homenajes localizados en la documentación gallega del siglo XV reflejan este elemento, como el de Suero Gómez de Soutomaior a Alonso de Fonseca II, en 1475, donde realiza el homenaje en manos de vos, Esteban de Junqueras ${ }^{136}$.

Y, finalmente el juramento solemne de aceptación por parte del vasallo y recepción de la fortaleza, Rocha Forte en este caso. Un juramento que en el pleito homenaje de 1463 de Álvaro Sánchez se materializa en la declaración prometio de lo guardar e conplir et mantener en todo segund de suso se contiene, so pena de traidor e a ter por ello en caso de menosvaler e en todas las otra penas en que caen et encurren los que non entregan las fortolezas aquellas de quien las reçeben e quebrantan su vondade et pleito et omenajen ${ }^{137}$.

\footnotetext{
131 Ibidem, p. 869-870.

132 AD, doc. 5. ACS, IG 702, fol. 302v․

133 Ibidem, p. 870.

134 AD, doc. 5. ACS, IG 702, fol. 301r ${ }^{\circ}$.

135 AD, doc. 5. ACS, IG 702, fol. 299r ${ }^{\circ}$.

136 López Ferreiro, A., Historia, cit., t. VII, ap. XXXVII, p. 135.

137 AD, doc. 5. ACS, IG 702, fol. 299r ${ }^{\circ}$.
} 
Toda ello va precedido de la renuncia del anterior poseedor, pero una renuncia aquí particular ya que ese poseedor era el propio Álvaro. El cambio es de señor al que rendir homenaje, no de vasallo.

Tres elementos pues, -volo, inmixtio manuиm y juramento de fidelidad- que derivan de las fórmulas del feudalismo y vasallaje clásicos y que aquí aparecen mutados en formulas bajomedievales de dependencia y vínculo en la clase nobiliaria. Con seguridad el pleito y homenaje se completaría con elementos simbólicos, como un paseo por las dependencias de la fortaleza, algo de lo que desgraciadamente no poseemos referencia.

Múltiples fueron las funciones de los tenentes de fortalezas de la baja Edad Media, desde la recaudación económica hasta la actuación como agentes de justicia o custodios de presos y delincuentes, así como, en ocasiones, representantes en Cortes designados por las ciudades ${ }^{138}$. El caso de Álvaro Sánchez se vio mediatizado tanto por su integración en la órbita episcopal compostelana como por la situación política vivida en la Compostela de mediados y segunda mitad del siglo XV.

Desde A Rocha Forte, don Álvaro actúa como verdadero señor del territorio, a medio camino entre la propia concepción nobiliaria medieval y los malos usos bajomedievales, fuente de tantas quejas y revuelta. Sus propios criados eran testigos de la actitud ciertamente despótica que Álvaro desarrollaba desde la fortaleza; es uno de sus criados y peatones, Juan de Espasande el que mejor refleja las razzias que se llevaban a cabo en el entorno:

de la dicha fortaleza se fazían muchos males y bellaquerías, que forçaban moças y mugeres casadas y salían a prender y rescatar gentes y tomaban las bacas y carneros y toçinos a los bezinos de la tierra y ansi mismo las cargas de pescado que benían a los puertos de la mar para la dicha çiudad de Santiago ${ }^{139}$.

Contamos incluso con algunas descripciones más explicitas, por ejemplo la de Rui do Aido: varios carreteros, entre ellos el testigo, acudían a Santiago trayendo carros de pan y leña para aprovisionar la ciudad, y hacen noche en un claro cerca de Combarro, cuando cae sobre ellos

el alcalde de la fortaleza de la Rocha Fuerte y otros quatro o çinco de caballo y peones y los tomaron a todos y los llebaron presos con sus carros

138 Castrillo Lamas, María de la Concepción, "Monarquía”, cit., pp. 102-103.

139 PTF, p. 450. Declaración de Juan de Espasande. 
y con lo que llebaban para la dicha fortaleza de la Rocha Fuerte, que no dexaran a ninguno salbo a este testigo porquel dicho Alcalde de la Rocha lo connosçía por causa del padre del testigo que hera criado del dicho Alcalde. $Y$ ansí dize el testigo que les tomaran el dicho pan y leña y cosas que llebaban en los dichos carros $[\ldots]^{140}$.

Pero tal actitud, en este caso, no era gratuita. En ocasiones se asocian tales acciones a una mera fechoría y opresión nobiliaria, reduciéndola a una dicotomía delincuente-víctima, sin atribuir un sentido más amplio ${ }^{141}$; pero la actividad de don Álvaro poseía una orientación clara, más allá de las propias tropelías finales de los años 50 del siglo XV: el desabastecimiento de la ciudad de Santiago. Éste es un momento en que el núcleo compostelano se levantaba contra su prelado, don Rodrigo de Luna. La acción de don Álvaro estaría orientada a mantener una autoridad férrea, imponiendo el miedo y evitando el abastecimiento completo de la ciudad de Compostela ${ }^{142}$.

Es ahora, hacia mediados de siglo, en 1458, cuando se constituye la Hermandad que se opone al señorío de la iglesia de Santiago, hermandad precursora de la que participaría en la guerra irmandiña. Con el arzobispo compostelano don Rodrigo ausente, en la guerra de Granada, doña Juana de Castro, viuda de Rodrigo de Moscoso, su hijo Bernal Yáñez, principal ejemplo de los intereses nobiliarios en los núcleos urbanos de la Galicia del momento ${ }^{143}$, y otros nobles y oligarcas de los municipios de Santiago, Noia y Muros, hacen juramento de defender unas libertades que consideraban restringidas por el arzobispado compostelano ${ }^{144}$. Eran precisamente actos como los llevados a cabo por don Álvaro desde A Rocha, actos de usurpaciones, robos, raptos, etc. lo que ellos enarbolaban como acusación principal.

140 PTF, p. 450. Declaración de Rui do Aido.

141 Ruíz, Teófilo, Historia, pp. 204 ss.

142 En palabra de Salustiano Portela Pazos, que retoma pasajes de Vasco de Aponte, «el alcaide Álvaro Sánchez de Ávila se sostenía y "bravamente hostilizaba a los compostelanos", tornándoles el aprovisionamiento, harto dificultoso". Portela Pazos, Salustiano, Galicia en tiempo de los Fonsecas, Madrid, 1957, p. 33. Unas acometidas y hostilidades que también destaca López Ferreiro en López Ferreiro, A., Historia de la Santa A. M. Iglesia de Santiago, t. VII, Santiago de Compostela, 1904, p. 228.

143 Portela, Ermelindo; Pallares, M. ${ }^{a}$ Carmen, "De Gelmírez a los irmandiños. Conflictos sociales en la ciudad de Santiago", El Camino de Santiago: Estudios sobre la peregrinación y sociedad, Madrid, 2000, pp. 128-129.

144 Pallares, M ${ }^{a}$ Carmen; Portela, Ermelindo, "Compostela y la revuelta irmandiña", Universitas. Homenaje a Antonio Eiras Roel, t. I, Santiago de Compostela, 2002, p. 91. 
En medio de este clima de revuelta, y con una frenética actividad desarrollada desde A Rocha, en el año de 1459 el conde de Trastámara pone cerco al castillo. No era sólo una consecuencia de la acción de Álvaro Sánchez, sino que también existía un condicionante estratégico: Rocha Forte, por ubicación, potencia y contingente militar jugaba un papel decisivo en el abastecimiento y defensa-ataque de la ciudad $^{145}$. En el asedio de A Rocha participan el conde de Trastámara Pedro Álvarez Osorio, Bernal Yáñez de Moscoso, Suero Gómez de Soutomaior y Lope Pérez de Mendoza, que cercaron la fortaleza, como narra López Ferreiro y "abrieron fosos, levantaron empalizadas, montaron trabucos el máquinas para lanzar piedras y construyeron otros aparatos bélicos" 146 .

Pero la defensa fue férrea y el asedio difícil. El prelado compostelano don Rodrigo de Luna, ya de vuelta, era perfectamente consciente de la importancia de la fortaleza, no sólo como punto de defensa, sino por la presión que ejercía sobre el entorno compostelano. De ahí las reclamaciones que realiza ante Enrique IV en el momento en que los levantiscos, comandados por Pedro Álvarez Osorio, cercan el enclave; unas reclamaciones de las que se derivan tres provisiones reales en 1458 y 1459 conminando a la liberación del castillo ${ }^{147}$.

Fue tanto la determinación regia como, con toda seguridad, la certeza de que la toma de A Rocha sería una empresa en exceso difícil, lo que llevó a que se detuviese el asedio y, en 3 de septiembre de 1459, se produjese una reunión en el campo de Mazarelos entre los rebeldes, con el conde de Trastámara y Suero Gómez de Soutomaior a la cabeza, y la autoridad arzobispal, reunión que termina con una concordia y tregua por tiempo de seis meses. En tal acuerdo Álvaro Sánchez jugaba un papel fundamental. Evidentemente la actividad que desarrollaba desde la fortaleza, las acometidas llevadas a cabo por él y su compañía no eran bien recibidas; A Rocha se había convertido, para los mencionados caballeros, en una afrenta. Así, en la concordia se establece que Álvaro Sánchez debía de renunciar, durante el tiempo de validez del acuerdo, a la tenencia de la fortaleza, renuncia que debía hacerse efectiva en un plazo de veinte días ${ }^{148}$. Así, ya en ese mismo año de 1459 , García de Caamaño hace pleito y homenaje por el castillo de A Rocha quitándole temporalmente la tenencia a Alvaro Sánchez ${ }^{149}$.

145 Así, "seguía contando el arzobispo con un eficaz aliado en las proximidades de Compostela, el acalde de la fortaleza de la Rocha Fuerte, que suponía un serio inconveniente para el libre suministro de provisiones a la ciudad". Ibidem, p. 93.

146 López Ferreiro, A., Historia, p. 231.

147 Portela, Ermelindo; Pallares, M ${ }^{\text {a }}$ Carmen; Sánchez, Xosé M., Rocha, cit., p. 74.

148 Ibidem, pp. 231 ss.

149 AHD, Fondo General, Catálogos, leg. 3, I, fol. 56v . 
El plazo de seis meses sería empleado en intentar llegar a un acuerdo más duradero y, en el caso de que no fuese así, la posesión del enclave tendría que ser devuelta a don Álvaro. Y exactamente así fue llevado a cabo: hacia finales de febrero de 1460, sin un acuerdo mayor, A Rocha volvió a manos de Álvaro Sánchez de Ávila.

Pero el levantamiento de 1458 volvería a repetirse con la guerra irmandiña ${ }^{150}$, sobre la base, en parte, de las mismas características, cifradas por Ermelindo Portela y $\mathrm{M}^{\mathrm{a}}$ Carmen Pallares en "los nobles establecidos en Compostela, los representantes del concejo, los canónigos, la tensión con el arzobispo y su poder señorial, la relación con las villas de Noia y Muros, la constitución de la hermandad y el desarrollo de los conflictos"151. Tenemos nuevamente a Bernal Yáñez opuesto al prelado compostelano, ahora Alonso de Fonseca II, al servicio del cual se mantiene don Álvaro como casteleiro de A Rocha, desde la que no cesa de acosar a los habitantes del entorno de la ciudad, con episodios como el rapto de una joven compostelana y su violación ${ }^{152}$, episodio narrado en el Tabera-Fonseca, y que provoca una situación difícilmente sostenible.

\begin{tabular}{|l|c|}
\hline \multicolumn{1}{|c|}{ CASTELEIRO } & AÑO \\
\hline García Gutierrez $^{153}$ & 1333 \\
\hline $\begin{array}{l}\text { Pero Gomes de } \\
\text { Argomedo }\end{array}$ & 1338 \\
\hline $\begin{array}{l}\text { Juan Martiño de } \\
\text { Lobeira }\end{array}$ & $\begin{array}{c}1448- \\
\text { post. } 1450^{154}\end{array}$ \\
\hline $\begin{array}{l}\text { Álvaro Sánchez de } \\
\text { Ávila }\end{array}$ & cc. $1455-1459$ \\
\hline García de Caamaño & $1459-1460^{155}$ \\
\hline $\begin{array}{l}\text { Álvaro Sánchez de } \\
\text { Ávila }\end{array}$ & $1460-1466$ \\
\hline
\end{tabular}

Casteleiros de Rocha Forte documentados en los siglos XIV y XV.

Fuente: Portela, Ermelindo; Pallares, M ${ }^{a}$ Carmen; SÁnCheZ, Xosé M., Rocha, cit. e ACS

150 Un levantamento que entronca perfectamente con la tradición levantisca compostelana, que se inicia ya en el siglo XII y tiene sus hitos principales en época de Gelmírez, en los años 1116 y 1136, en la de don Berenguel de Landoira, en 1318-1320, y con esta guerra irmandiña. Portela, Ermelindo; Pallares, M. ${ }^{a}$ Carmen, "De Gelmírez", cit., p. 107-108.

151 Pallares, $\mathrm{M}^{\mathrm{a}}$ Carmen; Portela, Ermelindo, "Compostela", cit., p. 94.

152 PTF, pp. 461-462.

153 ACS, S20/7.

154 ACS, S19/7.

155 Por período de seis meses, em virtud de tregua. 
Así, la revuelta del 66, con la entrada en juego plenamente del campesinado, tiene a A Rocha Forte como uno de los principales objetivos de los sublevados en Compostela, en el plano extramuros. Desde un primer momento la multitud, en la que participan también sectores urbanos además del campesinado y de sectores nobiliarios, cercan el enclave, la posieran sobre estacas y la derrocaron ${ }^{156}$. Suponemos que don Álvaro permanecería en la defensa del castillo, tanto de A Rocha como del señor al que servía, don Alonso de Fonseca II; pero el empeño fue en balde y, finalmente, cayó el enclave.

Después de once años, como mínimo, don Álvaro Sánchez de Ávila ya no sería más, de facto, el tenente o alcaide de A Rocha Forte.

Pero no terminó aquí ni la vida militar del Álvaro Sánchez, ni su papel como tenente de un enclave fortificado. Parecía tener bien claro el servicio a su señor, el prelado de Santiago; así, tras la caída de A Rocha, y luego de algún otro episodio militar insertado en la épica, como el de Altamira de 1471, lo volvemos a encontrar, ya en la década de los 80 , como teniente de uno de los castillos más representativos, recios y antiguos del arzobispado compostelano: la fortaleza de A Barreira, tenencia que debió de ocupar hasta poco antes de su muerte en 1489.

Tanto en el núcleo fortificado como en la merindad de A Barreira se centralizaban el cobro de determinados impuestos, diezmos, servicios y alcabalas de la tierra y mayordomazgo de Tabeirós aunque, siendo don Álvaro el tenente, recibió el pago de zonas más lejanas, como la villa de Redondela, y Teis o Cedeira ${ }^{157}$. De hecho, hasta el siglo XVI A Barreira fue el único castillo que recibió dinero del arzobispado para su mantenimiento y, tras el derrumbamiento de A Rocha Forte de Santiago, A Barreira se erigió en el principal castillo de la mitra, junto con los palacios arzobispales de la ciudad compostelana ${ }^{158}$.

En los años 80 del siglo XV don Álvaro continuaba cumpliendo en A Barreira una función que ya había desarrollado en A Rocha Forte: la gestión del cobro de impuestos. Mientras en el castillo compostelano se trataba de las mercancías que venían por el Camino Real para Santiago, ahora eran los pagos de Tabeirós; suponemos que desde el arzobispado se buscó a alguien experimentado en tales lides, además de las propiamente militares.

No hay más datos de esta tenencia que los meramente económicos, aunque podemos decir que A Barreira se erigía en núcleo feudal y foco del poder arzobis-

156 Declaración de Pedro de Ramil. PTF, p. 457.

157 LR, 1, fol. $15 \mathrm{v}^{\circ}$.

158 Olivera Serrano, César, El ocaso, cit., pp. 38-40. 
pal en su entorno, con don Álvaro como vasallo que la había recibido en pleito y homenaje. Los impuestos que en este enclave se centralizaban eran bastante destacados, resaltando en los Libros de Recabdança los pagos en especie para el mantenimiento del propio castillo, destacando el pago en vino.

\begin{tabular}{|l|c|c|}
\hline \multicolumn{1}{|c|}{ Entidad pagadora } & Mercancía & Año \\
\hline $\begin{array}{l}\text { Mayordomazgo de la villa } \\
\text { de Redondela, con Teis y Cedeira }\end{array}$ & 180 azumbres de vino ${ }^{159}$ & 1481 \\
\hline Mayordomazgo de Tabeirós & 133 fanegas y media de pan & 1481 \\
\hline $\begin{array}{l}\text { Mayordomazgo de la villa de } \\
\text { Pontevedra }\end{array}$ & 565 azumbres de vino & 1481 \\
\hline Mayordomazgo de Cobres & 90 azumbres de vino & 1481 \\
\hline Cámara de Entrambos Ríos & 555 azumbres de vino ${ }^{160}$ & 1481 \\
\hline Mayordomazgo de Tabeirós & 133 fanegas y media de pan & 1482 \\
\hline Mayordomazgo de Caldas de Reis & 3 toneis de vino & 1482 \\
\hline
\end{tabular}

Pagos recibidos por Álvaro Sánchez de Ávila como alcaide de la fortaleza de A Barreira en 1481 e 1482.

Fuente: LR.

Tales ingresos corresponden a los denominados retenencia y bastimentos, es decir, determinadas cantidades para asegurar el abastecimiento del enclave y el mantenimiento del edificio y de la tropa, con ropa, armas, etc. ${ }^{161}$, pagos realizados en metálico o, como en este caso, en especie.

Su salida como alcaide del castillo se produce en algún momento entre 1482 y 1489, aunque, como ya dijimos, nos decantamos por situarla hacia el final de la década, ya que la altura de 1489 se le debía una cantidad de 300 fanegas de mijo de quando salio de la Barrera ${ }^{162}$. A don Álvaro le sucede como teniente del enclave Francisco Ortiz, antiguo tenente de Pico Sacro ${ }^{163}$-lo que sin duda supuso un ascenso para éste-.

159 Compartidos con Balboa, alcaide de la fortaleza de Lobeira.

160 Idem.

161 Vazquez Bertomeu, Mercedes, La hacienda, cit., p. 62.

162 LR, 2, fol. 9v $v^{\circ}$. Otra referencia del LR nos situa el fallecimiento de don Álvaro en ese 1489, pero ello no implica que la renuncia de A Barreira no haya sido anterior a ese ano.

$163 \mathrm{LR}, 2$, fol. $9 \mathrm{v}^{\circ}$. 
¿Cuál era el contingente y armas que un castillo como este podía albergar o del que podía disponer para su defensa? El caso de A Rocha Forte fue borrado por la fogatas irmandiñas, pero para el de A Barreira contamos con un testimonio tardío pero muy destacable. El 2 de octubre de 1524 Francisco Sánchez, mayordomo de Alonso de Fonseca, ya arzobispo de Toledo, hace entrega al nuevo prelado de Santiago, don Juan Tabera, de las armas y fortalezas del templo de Santiago para su defensa; una entrega de la que poseemos un valioso inventario realizado por el arriba mencionado Francisco Sánchez ${ }^{164}$. Aparecen aquí referencias a las armas que en ese momento se encontraban en A Barreira, las cuales no debían de diferir en demasía de las que poseería en su tiempo Álvaro Sánchez, excepto quizá por una menor difusión de las armas de fuego y pólvora:

(fol. $1 r^{\circ}$ ) Yo Antonio del Corral, portero de Cámara de su magestad e su escrivano e notario publico, por las abtoridades apostólica e real doy e fago fee e verdadero testimonio a todos los que la presente vieren como en mi presençia e de las testemoyas de yuso escriptas, en la çibdad de Santiago, a dose dias del mes de otubre, ano del Señor de mill quinientos e beynte e quatro, anos despues de aver tomado la posesyon de la yglesia e çibdad de Santiago por el liçençiado Loys( ¿) de Almoranç e Christoval de Saldaña, continno(¿) de su magestad, en nombre del y del Yllmo. Señor don Juan Tabera, arçobispo de Santiago, estando dentro del palaçio del dicho señor arçobispo, pareçio presente Francisco Sanches, vecino e regidor de la dicha çibdad de Santiago, mayordomo del yllistrisimo (sic) señor don Alonso de Fonseca, arçobispo de Toledo, e diço al dicho Christoval de Saldaña que en nonbre del dicho señor arzobispo de Santiago le entregava e entregó por de la yglisia e para la defensión della las armas seguientes:

Primeramente en la yglesia de Santiago e fortalesa de la Barrera, donde es alcayde Ares Pardo:

Veynte valeestas con sus gafas. E más dixo el dicho Francisco Sanches que estavan allí en la dicha fortalesa e ygleisia sesenta e tres valeestas en depósito que se avian tomado en el arçobispado con algunas gafas e poleas e armatostes que asy mismo se les entregavan por que estoviesen en el dicho depósito.

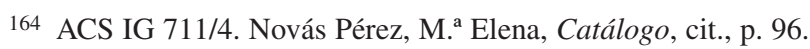


Et más le entregó tres armas llenas de seetas de almaçán. Et más otras veynte e quatro dozenas de almaçán, las ocho de Altamyra y las dies y seys de Viscaya, ay [...] as sin yerros de las dies e seys dozenas. Et más le entregó treynta escopetas y treynta e tres libras de plomo. Et más doze frascos e quatro çabaderos. Et más treynta escudos con seys $q[\ldots] s[\ldots]$ en la Barrera. Et más çinco arcabuzes, los quatro desencabalgados e el vno encavalgado. Et más le entregó nueve coseletes enteros que algunos les faltan algunas piesas, que son estos los que se tomaron del Altar. Et más le entregó honse coseletes y quinse çeladas y veynte e tres braçales. Et más dos dozenas de rodelas. Et más vna dozena de alabardas, et más dozientas picas. Et más doze tiros de fuego, falonetes de yero con sus cabaletes de palo, los says con servidores e los seys syn ellos. Et más tres cueros llenos de pólvora. // (fol. 1vo ) Et más le entregó honze gorjaes de malla e çierta malla vieja que avia sydo de vn seys e vna cota vieja de malla. Et más le entregó vn serón de almaçán de Viscaya ${ }^{165}$.

Un completo conjunto de armas que nos da idea del contingente existente en un castillo gallego bajomedieval, y que fortalecería con seguridad A Barreira no sólo en el momento del siglo XVI en el que fue redactado sino ya en el XV, cuando don Álvaro Sánchez era alcaide.

Fue la tenencia de A Barreira el último servicio a su señor, la prelatura compostelana, y uno de los últimos episodios de su existencia. Pero el recuerdo que permaneció de don Álvaro como tenente de A Rocha no fue fácil de borrar y es lo que ha pasado a la historia. Incluso en 25 de octubre de 1485, después de la destrucción del castillo compostelano, siendo ya teniente de A Barreira, Álvaro es referido en un tomo de actas capitular, en el nombramiento de un nuevo tenenciero de la tenencia de Reis -de la que él poseía diversas propiedades aforadas-, con el título de Alcalde de la Rocha ${ }^{166}$, el mismo que se emplea en diversas referencias del Libro de Recabdanças.

Dos caras bien definidas: guerrero del arzobispo y temor de los habitantes del entorno de Compostela.

165 ACS IG 711/4, fol. $1 \mathrm{r}^{\mathrm{o}}-\mathrm{v}^{\mathrm{o}}$. El documento se completa con la entrega de las armas de las fortalezas de Pontevedra, Torre de la Plaza de Santiago, Castro de Montes, Padrón, Outes, Lobeira, Pico Sacro, Mesía, Grobas, Rodeiro, Melide, Noia y Xallas.

$166 \mathrm{AD}$, doc. 11. ACS, IG 476, fol. $69 \mathrm{v}^{\circ}$. 


\section{EL CABALLERO Y LAS BURGUESAS: FUNDAMENTACIÓN DEL PATRIMONIO Y PODER SOCIAL. UN PARADIGMA DE LA GALICIA BAJOMEDIEVAL EN LA TRANSICIÓN HACIA LA MODERNIDAD}

Grosso modo la función militar de la nobleza medieval estaba sostenida por un sistema socioeconómico que le permitía obtener los recursos necesarios para el desempleo de su actividad y mantenimiento de su status. Un sistema basado en las tres clases sociales, genéricamente definidas como nobleza, clero y campesinado.

Pero el mundo cambiaba, la sociedad, sumida en una crisis económica desde el siglo XIV, mudaba a nuevas formas de organización social y obtención de recursos. La burguesía y las oligarquías urbanas adquirían, a nivel europeo y, por supuesto, gallego, una importancia de la que anteriormente carecían, mientras la nobleza se veía acuciada por la escasez de ingresos, presionando como consecuencia a las clases más bajas.

Sumidos en tal situación los miembros de la nobleza desarrollaron diversos mecanismos para sortear las dificultades y acceder de nuevo al capital. Matrimonios con la elite urbana, inversión en tierras, nuevos foros... gran variedad de fórmulas, algunas de las cuales observamos ya en don Álvaro Sánchez de Ávila, un noble que mantiene intacta la función de miles y las concepciones nobiliarias medievales.

A nivel del reino de Castilla, el siglo XV es el momento de verdadero enriquecimiento de la nobleza que, con la revuelta trastamarista, había ascendido como elite social en la segunda mitad del siglo XIV. Se conforman ahora grandes y extensos dominios señoriales, como los de Álvaro de Luna o el marqués de Villena, y se desarrollan paralelamente diversas prácticas orientadas al refuerzo de la propia clase nobiliaria: el incremento de los señoríos territoriales a través de la apropiación de terrenos realengos o concejiles; el incremento de los mismos a expensas de los pequeños propietarios o de la baja nobleza; y el desarrollo de políticas matrimoniales que favoreciesen el enriquecimiento o el afianzamiento de las familias y linajes ${ }^{167}$. Al mismo tiempo, en función del ámbito geográfico, encontramos recursos específicos como la participación nobiliaria en la producción ganadera como forma de inversión, aprovechando el desarrollo del mercado de lana en Castilla ya desde el siglo XIV.

La relación matrimonial, no sólo en el momento que nos ocupa sino a lo largo del medievo, no era tomada únicamente desde el punto de vista personal, sino que,

167 Fernández Conde, Francisco J., La España, cit., p. 76. 
por una parte, suponía un paso a la madurez de la vida pero, por otra, se veía tremendamente influida por elementos políticos, económicos y sociales ${ }^{168}$.

Los sentidos atribuidos a los enlaces son diversos: el refuerzo del propio status de uno de los contrayentes y su linaje; el ascenso en la categoría social; o el refuerzo de una posición económica débil a pesar de la pertenencia a la clase nobiliaria ${ }^{169}$. Por otra parte, lo que se podría denominar mercado matrimonial presenta, en el ámbito urbano de la baja Edad Media, para el siglo XV, un importante dinamismo, encontrando en no pocas ocasiones segundos matrimonios vinculados a la clase nobiliaria ${ }^{170}$.

En el caso de Álvaro Sánchez, es en los años 70 cuando su situación debió de empeorar. Por una parte pierde la posesión de A Rocha, con todo lo que ello implica en cuanto a la obtención de recursos económicos e influencia en el entorno compostelano; por otra, intuimos que tras la batalla de Altamira, en 1471, su estado no era óptimo, con el físico quizá algo deteriorado por la actividad militar y también con el fallecimiento de su primera señora, María González. Pero además se ve inmerso en un proceso más general a nivel del reino de Galicia. Tras los enfrentamientos y guerra que asolaron la Galicia en las décadas 60-70 del siglo XV, con la llegada de los Reyes Católicos la situación cambió para la nobleza gallega, ahora más controlada y bajo a atenta mirada de la justicia real y de las Cortes. De esta forma en las Cortes de Toledo de 1480 se llevó a cabo un reajuste en las mercedes percibidas por la nobleza gallega rebajando las cantidades ${ }^{171}$. En el listado de nobles que se refiere en las Cortes aparece, junto a otros, Álvaro Sánchez de Ávila ${ }^{172}$. Aquí se recoge la cantidad que don Álvaro percibía, 10.000 maravedíes; era una cantidad baja, si a comparamos con los 550.000 maravedíes percibidos por Pedro Álvarez Osorio o los 160.000 de Pedro Álvarez de Soutomaior. Aún así, pese

168 "El matrimonio no solamente representaba para la nobleza medieval el cambio de estado de uno de sus miembros y, por tanto, su transformación en el seno de la familia y de la sociedad, sino el enlace entre los linajes y, por lo mismo, una posible vinculación futura de intereses y haciendas en los descendientes". Beceiro Pita, Isabel; Córdoba de la Llave, Ricardo, Parentesco, cit., p. 125.

169 Vid. ibidem pp. 143 ss.

170 Ibidem, p. 165.

171 Además, la nobleza que poseía fortalezas realengas en tenencia -aunque no es el caso de Álvaro Sánchez- percibía una determinada cantidad de la monarquía castellana, denominada tenencia o retenencia, cantidad orientada al mantemento del enclave, en lo que atañe a reparaciones, abastecimiento, etc.; una cantidad que variaba en función de la importancia del castillo poseído. Castrillo Lamas, María de la Concepción, "Monarquía”, cit., pp. 104-105.

172 García Oro, recogiendo la información de Matilla Tascón, hace referencia a Alonso Sánchez de Ávila, aunque que con toda seguridad se trata de Álvaro, cuyo nombre aparecería con la abreviatura $\mathrm{A}^{\mathrm{o}}$ y fue transcrito por Alonso. García Oro, José, Galicia, t. I, cit., p. 349. 
a no ser mucho, la reducción fue total, eliminándole la percepción de mercedes y disminuyendo consecuentemente sus recursos económicos.

Tengamos en cuenta que, a estas alturas, hace ya cerca de quince años que don Álvaro no es tenente de A Rocha y había perdido la preeminencia e importancia de la que había disfrutado con don Rodrigo de Luna y con Alonso de Fonseca. A tal situación se añade esa nueva circunstancia de unos ingresos eliminados en las Cortes.

La situación de don Álvaro no es única, ni mucho menos. Buena parte de la nobleza bajomedieval sufre ahora dificultades económicas; dificultades que reafirman determinadas políticas matrimoniales y que conducen a una estrategia clara para su supervivencia en el seno de la clase social nobiliaria: la alianza matrimonial con la burguesía. Es así como llegamos al enlace con señora Inés García. Tales alianzas y la aproximación a comportamientos relacionados con el incipiente y reducido capitalismo que se comenzaba a desarrollar en las ciudades gallegas del bajo medievo, resultan característicos de las capas bajas nobiliarias, como la hidalguía, o de nobles venidos a menos que, manteniendo su status, verían peligrar en mayor o menor medida los recursos económicos ${ }^{173}$.

Tal política matrimonial no es exclusiva del ámbito gallego, sino que contamos con múltiples ejemplos en el reino portugués, además del entronque de las casas gallegas con las portuguesas. En la baja Edad Media y transición hacia la modernidad la vinculación de ciertos elementos de la nobleza con la burguesía urbana responde tanto al enriquecimiento de la segunda como a la reducción de ingresos por parte de la primera ${ }^{174}$.

Ciertamente, en el matrimonio medieval los sentimientos no permanecían completamente lateralizados; poseemos diversos casos en los que en un testamento encontramos mandas o referencias a la esposa dedicadas con respeto y cariño ${ }^{175}$. Pero, como ya hemos comprobado, el de don Álvaro Sánchez no es un de ellos.

Tras el fallecimiento del tenente de A Rocha y A Barreira doña Inés no debió de llorarlo en demasía, por lo menos eso es lo que se deduce de su testamento, donde lo trata con enorme frialdad. Por otra parte, desde un punto de vista más teórico, en la Galicia bajomedieval la viudez es el momento que permite a la mujer sobrepasar el límite social de lateralización con respecto al centro del poder en el sistema señorial ${ }^{176}$.

173 Por ejemplo, en Ourense la familia nobiliaria Cadórniga entronca con la del escudero Vasco Fernández de Ramuín, en 1421, co intensa presencia entre la burguesía urbana. López Carreira, Anselmo, A cidade de Ourense no século XV. Sociedade urbana na Galicia baixomedieval, Ourense, 1998, p. 330.

174 Paredes Mirás, $\mathrm{M}^{\mathrm{a}}$ del Pilar, Mentalidade, cit., pp. 158-159.

175 Vid. Pallares Méndez, M. ${ }^{a}$ Carmen, "Las mujeres en la sociedad gallega bajomedieval”, en Pastor, Reyna (comp), Relaciones de poder, de producción y parentesco en la Edad Media y Moderna, Madrid, 1990, p. 363.

176 Ibidem, p. 362. 
Pero además don Álvaro desarrolló otro medio de afianzamiento económico. La posesión de propiedades rurales, tanto su posesión como el usufructo, constituye uno de los principales elementos generadores de riqueza en lo que atañe a la nobleza bajomedieval ${ }^{177}$. De hecho, en los recuentos de propiedades y los testamentos, son los caseríos o heredades los conjuntos que tienen una mayor presencia, tanto en propiedad y disfrute directo como cedidos por rentas que reportaban destacables beneficios $^{178}$.

\begin{tabular}{|l|l|}
\hline TOPÓNIMO & DENOMINACIÓN \\
\hline San Miño de Ares & $1 / 2$ beneficio sencura \\
\hline San Miño de Ares & Ermita (patronazgo) \\
\hline San Adrián de Corme & $1 / 4$ beneficio sincura \\
\hline Santa María de Xestenla & Ermita \\
\hline Exo & Renta de \\
\hline Rúa de Algalia de Cima & \\
\hline (Santiago de Compostela) & 2 casas \\
\hline Algalia de Abaixo & \\
\hline (Santiago de C.) & Cortiña \\
\hline Corto (Seaia) & Casal \\
\hline Çerdido (Montaos) & Casales \\
\hline Piñeiro & Casal \\
\hline Vendaña & Tierra de \\
\hline
\end{tabular}

Propiedades referidas en el testamento de don Álvaro Sánchez de Ávila. Fuente: AD, doc. 12. ACS, LD 5/1.

Las referencias concretas realizadas en el testamento de don Álvaro no revelan un conjunto demasiado grande de propiedades, pero si les añadimos la posesión, por delegación de la iglesia compostelana, de los cotos de Ons, Calvos y Santiso, y si consideramos los beneficios y derechos de presentación que poseía sobre varias iglesias, como San Miño de Ares o San Adrián de Corme, los ingresos recibidos por esta banda no debían de ser desdeñables. Estas eran las propiedades que, en el siglo $\mathrm{XV}$, se integraron en la denominada Tenencia Grande del Cabildo, para enajenarse

\footnotetext{
177 Gelabert González, Juan Eloy, Santiago y la tierra de Santiago de 1500 a 1640, A Coruña, 1982, p. 274.

178 "La posesión o el usufructo de explotaciones agrarias va a generar, como forma manifiesta de acrecentamiento de estos ingresos, toda una serie de practicas especulativas alrededor de las rentas generadas". Ibidem, p. 275.
} 
después y tener una azarosa existencia en el seno del patrimonio capitular, especialmente a la hora de volver a ser arrendadas.

Su propio carácter personal y el papel de preeminencia que poseía en la corte arzobispal sirvieron a Álvaro para afianzarse en determinadas posesiones. Era un noble acostumbrado a hacer su voluntad y a un comportamiento seco, recio y casi parece que impulsivo. Así las cosas, las propiedades que los prelados compostelanos le habían concedido en ventajosos foros e inmejorables condiciones, con seguridad constituyeron un perfecto soporte económico en un momento en que las cosas no marcharon tan bien. Don Rodrigo de Luna había sido el que había favorecido el arrendamiento de las propiedades en unas condiciones muy favorables. Pero, como en toda economía, una cesión de bienes que es buena para unos es pésima para otros: la iglesia de Santiago, o más concretamente el tenenciero. A la altura de 1463 el tenenciero capitular ${ }^{179}$, ya con don Alonso de Fonseca I como prelado y fallecido don Rodrigo de Luna, nos hace una pequeña narración del conflicto en el Tumbo III de Tenencias. La renta anual que pagaba don Álvaro era mínima, 400 maravedíes, en comparación con la que en realidad valían los cotos, $1.700^{180}$. Tales propiedades le reportaban además treinta hombres de señorío, 12 carneros y 2 vacas entre todos y 2 gallinas por hogar ${ }^{181}$. Ante tal situación el tenenciero, desde el fallecimiento de don Rodrigo de Luna en 1460 hasta este año de 1463, había presionado para arrebatarle el arrendamiento a don Álvaro, buscando una oferta mejor; de hecho afirma que eu quiserallos quitar des que morreo el arçobispo, porque me davan por eles mill moravedis de cada anno et mays de calças et huna mula de quoreenta dobras ${ }^{182}$. Pero un poder muy superior se interpuso: Fernan de Fonseca mandoume que o non fezese, quasy cominando de parte de noso sennor arçobispo don Afonso ${ }^{183}$. El favor de Álvaro Sánchez de Ávila en el arzobispado compostelano era demasiado grande. El tenenciero no puede más que dejar constancia de su lamento: Asy as ten en grande fraude et danno da teença ${ }^{184}$.

179 Acerca del sistema de tenencias vid. Pérez Rodríguez, Francisco Javier, El dominio del Cabildo Catedral de Santiago de Compostela en la Edad Media (siglos XII-XIV), Santiago de Compostela, 1994, pp. 57 ss. Ciertamente el núcleo de las tenencias era, en ocasiones, un conjunto amplio de propiedades donadas por una misma persona, como las donaciones realizadas por el juez de Luou, Payo Eanes, constituyendo la tenencia del juez don Payo.

180 ACS, CF 16, fol. VIIIv'.

181 ACS, CF 16, fol. VIIIv'.

182 ACS, CF 16, fol. VIIIv'.

183 ACS, CF 16, fol. VIIIv' - IXr $^{\circ}$.

184 ACS, CF 16, fol. IXr' ${ }^{\circ}$. 
No sólo eso, sino que en su testamento Álvaro Sánchez orienta la posesión de tales enclaves al abastecimiento y mantenimiento de sus descendientes; en concreto nombro por voz en el foro que yo tengo de los sennores e Cabildo de la santa yglesia de Santiago [...], segund se contiene en el contracto de aforamento, a mi fija Catalina Sanches ${ }^{185}$.

Don Álvaro estaría acostumbrado a ser señor de su fortaleza y, además, a conseguir concesiones, foros y arrendamientos en muy favorables condiciones para el momento, probablemente hacia los años 50 y 60 , cuando era alcaide del mayor castillo del reino de Galicia y uno de los más acérrimos defensores de los arzobispos compostelanos.

De ahí la situación que nos explica otra nota que sigue a la referencia la Oíns en ese Tumbo III de Tenencias: Este coto d'Oyns, con los cotos de Calvos y Santiso et todo lo mas que esta Tenençia Grande tenia en ellos, como lo tenia el alcalde de la Rocha, y otras heredades que el dicho alcalde tenia en fuero, se desmembro desta tenençia y se hizo tenençia nueba, la qual se dio en pregons al chantre don Juan Melgarejo, segund esta en el libro del procuratorio ${ }^{186}$. Una desmembración que tuvo lugar en reunión capitular del 24 de noviembre de $1512^{187}$.

Este tenenciero, de hecho, tiene que actuar de modo hábil para sacar rendimiento a la tenencia en tales cotos. Cuando el Cabildo, por una deuda que había contraído su anterior tenenciero el canónigo Fernán Raposo, anexa a la Tenencia Grande determinadas heredades que pertenecían a la Tenencia de los Deanes, el canónigo Vasco Martíns afirma: estas herdades non van con o foro del alcayde, colloas eu et tennoas arrendadas a çertos labradores a pan ${ }^{188}$. Frase escrita casi con rabia y que denota, a buen seguro, un sentir general.

La situación vivida dejó huella, y bastante fuerte, ya que se tuvo en cuenta para cesiones futuras. El 24 de noviembre de 1512, tal y como se recoge en las actas capitulares, el Cabildo acuerda unir y hacer un todo con las propiedades que anteriormente habían sido aforadas a don Álvaro: el coto de Oíns, los cotos de San Pedro de Miños de Calvos, de So Camino Francés y de Santiso. Todos ellos son unidos para poner el conjunto en Cabildo a laylan y almoneda y poder ser aforado -constituyendo la que será tenencia de Santa Baia de Vedra- pero determinando dos condiciones, de las cuales nos interesa la primera: que la persona que oviere de

185 ACS, doc. 12. ACS, LD 5/1, fol. $1 v^{\circ}$.

186 ACS, CF 16.

187 Unha desmembración da tenza dos coutos e propiedades que estaban aforados al allcaide de la Rocha. ACS, IG 478, fol. $383 v^{\circ}$.

188 ACS, CF 16, fol. IXr' 
sacar lo suso dicho sean (sic) benefiçiado de la yglesia y no lego y que aquel ny el dicho Cabildo y non lo puedan enajenar ni dar a persona lega ${ }^{189}$. Parece que se trata de evitar una sustracción o intromisión en la jurisdicción y propiedad capitular, como probablemente había ocurrido con don Álvaro; era por ello por lo que en el coto de Oíns os que ende moran [dicían] que poden viver con cada huun dos sennores do dito couto qual quiseren, lo cual no beneficiaba en nada a la institución compostelana. Notemos que es este un momento en el que, desde el año de 1506, ya no ocupaba la prelatura compostelana Alonso de Fonseca II.

No fue este un caso único; en otros lugares se produjeron situaciones semejantes, en las cuales la nobleza se benefició de propiedades eclesiásticas, generalmente capitulares, y por causa de ello se llegó a una situación de enfrentamiento. Estamos pensando, concretamente, en la ciudad de Ourense, con diversos ejemplos de mediados del siglo $\mathrm{XV}^{190}$.

Incluso con don Álvaro desaparecido no finalizaron los problemas para el Cabildo. En ese año 1512 se desarrolla un pleito con Isabel Sánchez de Ávila, nieta del teniente de Rocha Forte, y su marido, el secretario de la Real Audiencia Álvaro Núñez, por la posesión y foro de las propiedades que había tenido Álvaro Sánchez. La pequeña beliça se había concvertido ya en la mujer Isabel y parecía desear mantener los espacios donde se había asentado el poder de su familia.

Para tal pleito la institución catedralicia solicita un recuento de las propiedades poseídas por Álvaro, realizado precisamente por el que sería su heredero universal, Pedro de Almança. Pero la oligarquía constituye un grupo relativamente solidario y cerrado, y las reclamaciones capitulares caen en saco roto. En 18 de diciembre el recuento es solicitado a Pero de Babío, alcalde mayor de la ciudad de Santiago, pero la declaración que obtienen es que el dicho Pedro de Babio dixo que la verdad es que el tubo en su poder la dicha escriptura y recuento [...] pero que despues que en su poder la tubo la ha tornado a buscar entre sus escripturas y no la puede hallar ni sabe della y que juraba [...] que el ni otro por el, de que el sepa, no dio ni entrego la dicha escriptura a Alvaro Nuñez ${ }^{191}$. El Cabildo tendría que pelear si quería ganar aquella batalla.

Finalmente, en 1514, el pleito se resuelve por medio de un pago de 6.500 maravedíes por los derechos que Isabel Sánchez afirmaba poseer, y dichas propiedades son aforadas a ella y a su esposo Álvaro Núñez ${ }^{192}$.

189 ACS, IG 478, fol. $383 \mathrm{v}^{\circ}$.

190 Casos coma o preito do Cabido ourensán con Pedro Álvarez Osorio, cara 1452 ou co conde de Santa Marta, en 1454. López Carreira, Anselmo, A cidade, cit., pp. 325 y 367, nt. 115.

191 ACS, IG 478, fol. 393vo.

192 AD, doc. 18. ACS, IG 479, fol. 69vº. 
La posesión de bienes rurales y propios de terratenientes no excluyó, ni mucho menos, las propiedades urbanas, cobrando una mayor importancia para la nobleza gallega del siglo XV la renta inmobiliaria como medio de obtención de recursos. Así, encontramos referidas en el testamento de don Álvaro diversas casas en la ciudad de Santiago: dos en la calle de la Algalia de Arriba ${ }^{193}$, una en la Rúa do Vilar ${ }^{194}$ y las casas en las que él mismo vivía en la Moeda Vella, además de alguna otra propiedad urbana, como una cortiña en la misma Algalia195. Tales propiedades se insertan en esa tendencia de inversión urbana seguida por la nobleza gallega en la transición hacia la modernidad ${ }^{196}$, a pesar de que el recurso obtenido por las tierras y señoríos continuaba a ser fundamental; estamos ante de una diversificación de recursos en lo que atañe a la obtención de la renta.

A todo eso debemos de añadir un tercer aspecto, para obtener, a través del caso de Álvaro Sánchez de Ávila, una idea general de las principales estrategias nobiliarias de la Galicia bajomedieval: la participación en la vida política urbana, en este caso por medio del cargo de regidor.

El regimiento se concibe, tal y como lo define Armas Castro, como un órgano colegiado, con un número limitado de magistrados, y que constituye el centro fundamental del concejo medieval ${ }^{197}$. Un órgano que evoluciona desde las asambleas ciudadanas del siglo XII y que en la ciudad de Compostela, con el paso del tiempo, hacia la baja Edad Media, se va reduciendo tanto en sus integrantes, limitándose a vecinos de especial relevancia social o económica, como en el ámbito público de sus reuniones ${ }^{198}$. La actividad del concejo engloba múltiples esferas del funcionamiento de la ciudad, destacando: la organización económica de la misma, ejerciendo el control de los ingresos y los gastos; el abastecimiento del urbe; y el orden público y seguridad, junto a la administración de justicia ${ }^{199}$, tal y como se refleja, por ejemplo, en el Libro do Concello que recoge la actividad concejil entre los años 1416 y $1422^{200}$.

193 AD, doc. 12. ACS, LD 5/1, fols. $1 v^{\circ}$ y $2 r^{\circ}$.

194 AD, doc. 12. ACS, LD 5/1, fol. $1 v^{\circ}$.

$195 \mathrm{AD}$, doc. 12. ACS, LD 5/1, fol. $2 \mathrm{r}^{\circ}$.

196 Una tendencia observable también en otros núcleos, como Pontevedra. Armas Castro, José, Pontevedra, cit., p. 223.

197 Armas Castro, José, Pontevedra, cit., p. 274.

198 Pallares, M ${ }^{\mathrm{a}}$ Carmen; Portela, Ermelindo, "Reis", cit., p. 159.

199 Ibidem, p. 161-163.

200 Rodríguez González, Ángel, Libro del Concello de Santiago (1416-1422), Santiago de Compostela, 1992. 
Así, el arzobispado mantuvo siempre un enorme interés por ejercer su control sobre tal órgano. El centro fundamental del concejo compostelano del siglo XV está constituido por los justicias o alcaldes, los regidores, jurados u homes boos, el notario del ceoncejo y los procuradores. Mientras los alcaldes eran de nombramiento laico, los regidores, en número de doce, eran de nombramiento arzobispal, siendo un cargo de nombramiento vitalicio y por medio del cual se ejercía la función normativa en el seno de la institución ${ }^{201}$.

En el siglo XV, a nivel peninsular, la clase nobiliaria desarrolla un interés ya no sólo por la residencia en las ciudades -como don Álvaro, en la Rúa da Moeda- sino por la participación en la propia vida política y económica de los núcleos "rivalizando con otros de los grupos poderosos: el de los comerciantes y el formado por el patriciado urbano" 202 , un proceso tomado como una adaptación del feudalismo hacia el final de la Edad Media, algo que se traduce en Santiago en la participación de las familias más acomodadas de la ciudad en el concejo, especialmente en los cargos de alcaldes y regidores ${ }^{203}$.

Tal es el caso de Álvaro Sánchez. Desde las primeras referencias documentales la figura de don Álvaro aparece vinculada a la figura de regidor del concejo compostelano, siendo mencionado como Alvaro Sanches, alcayde da Rocha Forte de Santiago et rejedor que sodes da çibdade de Santiago ${ }^{204}$ ya en 1455; poco después, en 12 de junio de 1457, aparece confirmando un traslado de poder en la feligresía de San Bieito, como Alvaro Sanches de Avila, regidor da dita çidade ${ }^{205}$. Merced a la condición vitalicia del cargo es mantenido a lo largo de la segunda mitad del siglo, de forma que en 12 de enero de 1478 lo encontramos haciendo juramento de ayuda al Cabildo e iglesia compostelana junto con otros regidores y alcaldes de Santiago ${ }^{206}$. En el nombramiento de Juan Guedeja como tenenciero de la tenencia de Reis, en 25 de octubre de 1485, don Álvaro continúa siendo referido con dicho título ${ }^{207}$, y como tal, además, si intitula en el encabezamiento de su testamento, en 1489: Yo, Alvaro Sanches de Avila, regidor de la çibdad de Santiago ${ }^{208}$. Un cargo, así pues, que ostenta como mínimo desde 1455 hasta su muerte, casi treinta y cinco años más tarde.

201 Pallares, M ${ }^{\mathrm{a}}$ Carmen; Portela, Ermelindo, "Reis", cit., p. 160.

202 Fernández Conde, Francisco J., La España, cit., pp. 82-83.

203 Pallares, $\mathrm{M}^{\mathrm{a}}$ Carmen; Portela, Ermelindo, "Reis", cit., p. 161.

204 AD, doc. 1. ACS, S 16/13.

205 Fernández de Viana y Vieites, José Ignacio, El tumbillo de San Bieito del Campo (Santiago), Granada, 1995, doc. 36, p. 100.

206 AD, doc. 10. ACS, IG 475, fol . CCXXVIv.

207 AD, doc. 11. ACS, IG 476, fol. 69v .

208 AD, doc. 12. ACS, LD 5/1, fol. 1 $r^{\circ}$. 
A nivel general, en el reino de Castilla, fueron los caballeros de linaje o de baja nobleza los que trataron de fundamentar su poder de acuerdo con los privilegios fiscales y preeminencia política que obtenían en el juego de poder de las ciudades, tratando de acaparar en el siglo XV el cargo de regidor y, en algunas ocasiones, incluso el de corregidor, de nombramiento realengo ${ }^{209}$. El cargo de regidor implicaba la asunción de las principales atribuciones del funcionamiento urbano y de la vida local, con la administración de las rentas del municipio, el control sobre las obras públicas, la seguridad y defensa de la villa o la aplicación de normativas municipales, entre otras ${ }^{210}$. Un cargo en el que la nobleza puso pronto las sus miras y que, en este momento, es desempeñado principalmente por la oligarquía urbana y miembros de la clase nobiliaria ${ }^{211}$.

Si bien la organización concejil no se encontraba demasiado desarrollada en las villas de señorío arzobispal, en Galicia la institución experimentó un avance y actualización en la segunda mitad del siglo XV. En estas villas y ciudades, como Santiago, el nombramiento de los regidores era competencia del señor de la misma ${ }^{212}$, es decir: del prelado compostelano. Es por eso por lo que desde el arzobispado se otorga a un hombre de confianza como Álvaro Sánchez un puesto como éste, reforzando no sólo el dominio militar y efectivo del arzobispado sino también el político.

El caso de don Álvaro no es particular sino que, desde la nobleza, son muchos los que tornan su mirada e interés hacia las ciudades, ansiando reforzar su posición. Como ya introdujimos, nuestro caso posee una especial similitud con el de Gómez Pérez de las Mariñas, en A Coruña. Similitud por lo que respecta a los recursos y vías empleados para la obtención de recursos y de cotas de poder. Gómez Pérez, al igual que Álvaro Sánchez, fue también tenente, en este caso de la fortaleza de A Coruña, desde 1440, y también regidor del cocnejo, desde $1454^{213}$. Una doble vía de afirmación señorial y nobiliaria que reportaría un refuerzo tanto económico como político. El espejo coruñés de don Álvaro.

209 Fernández Conde, Francisco J., La España, cit., pp. 110-111.

210 Sánchez Chouza, José Manuel, A Coruña, cit., p. 173.

211 Grupos que, a pesar de todo, en no pocas ocasiones se enfrentan entre ellos. Ibidem, p. 174. También en la villa de Pontevedra, en el último cuarto del século XV, el oficio de regidor se tenía consolidado en el seno de la oligarquía y, dentro de ella, en un reducido número de familias. Armas Castro, José, Pontevedra, cit., p. 276.

Lo mismo ocurre en otras zonas del reino de Castilla. En Soria, por ejemplo, hacia mediados del la centuria, eran 12 los linajes hidalgos que se repartían y monopolizaban la institución concejil y cargos municipales. Diago Hernando, Máximo, "Caballeros y hidalgos en la Extremadura castellana medieval (siglos XII-XV)", En la España medieval, n 15, Madrid, 1992, p. 24.

212 Armas Castro, José, Pontevedra, cit., p. 274.

213 Sánchez Chouza, José Manuel, A Coruña, cit., pp. 111-112. 
Constatamos así el desarrollo de diversas estrategias por parte de la nobleza gallega bajomedieval, acuciada por la crisis e insertada en una coyuntura más amplia a nivel peninsular, estrategias orientadas a una diversificación en la obtención de recursos económicos y a un incremento de las cotas y esferas del poder detentado.

Tales prácticas, documentadas en el caso de don Álvaro Sánchez de Ávila, se materializan en tres ámbitos. En primer lugar un desarrollo de políticas matrimoniales ventajosas, que reporten el acceso a las clases burguesas y oligárquicas, en posesión de influencia no sólo social sino monetaria y que, por su parte, ansiaban el acceso a la nobleza de título; tal condición resulta patente en el primer matrimonio de Álvaro, con María González, y especialmente en el segundo, con Inés García. En segundo lugar una inversión en tierras y posesión de bienes aforados y arrendados, patente en los cotos de Calvos y Santiso, un caso marcado por el beneficio que el arzobispado compostelano ofrecía a uno de sus más preciados valedores; ventajas que el tenenciero rechazaba pero frente a las que no podía hacer más que rebelarse de palabra. Y, finalmente, como tercer soporte, tenemos la participación en la vida política urbana, con los regimientos como principal objetivo y como medio de asentamiento de la esfera de poder nobiliaria; un cargo, el de regidor, que Álvaro Sánchez ostenta en el concejo de Santiago, por nombramiento arzobispal, desde 1455 hasta su último viaje: su fallecimiento en 1489.

\section{TEMÉNDOME LA MUERTE. LA MUERTE DE UN CABALLERO EN LA GALICIA BAJOMEDIEVAL.}

Fue la lectura y el análisis de los dos testamentos que se contienen en nuestro Apéndice Documental -con especial atención al de don Álvaro Sánchez- lo que nos devolvió a la verdadera perspectiva de la Historia, tomando nuevamente conciencia del hecho de que no trabajamos únicamente en base a pergaminos, a una serie de transacciones económicas o a meros vaciados de información, sino sobre la existencia de personas que sintieron y vivieron como nosotros y de cuya mentalidad se impregnan buen parte de este tipo de documentos postreros, permitiéndonos no sólo tratar mandas relacionadas con las propiedades, donaciones y herencias, sino algunos de los aspectos más arraigados en la propia mentalidad del mundo medieval.

En el presente apartado no trataremos todas las informaciones que se podrían extraer de este segmento de la documentación ya que, por ejemplo, no haremos consideraciones particularizadas acerca de las donaciones, sino que ofreceremos una 
visión de los testamentos como fuente en la transición de la Edad Media a la Modernidad en Galicia, a través de la observación del caso concreto de don Álvaro.

De esta forma, y como punto de partida más general, debemos considerar el hecho de la religiosidad. Este es un ámbito del mundo de las mentalidades que imbuye buen parte del contorno del hombre medieval por medio de la certeza de la muerte, de la asunción de una vida más allá y de la posibilidad, más que próxima, de penar por las faltas cometidas en vida, que da origen a las fuentes testamentarias ${ }^{214}$.

Tomamos como principio o guía la afirmación de Leonor Gómez Nieto de que "la muerte es siempre histórica" 215 , debiendo de hacer quizá la precisión -por lo que respecta a la historia medieval- de que lo es siempre que quede algún tipo de resto documental, ya sea escrito, arqueológico o artístico. Una muerte histórica que, como aclaran Ermelindo Portela y M. ${ }^{a}$ de él Carmen Pallares, se prolonga en el tiempo: hacia atrás por la certeza de una enfermedad grave y la inminente agonía, y hacia adelante por los rituales, exequias y funerales dispuestos; tal período, desde la enfermedad hasta el enterramiento, es lo concebido como el espacio de la muer$\mathrm{te}^{216}$. Dicho espacio de la muerte, en el caso de don Álvaro Sánchez, podemos localizarlo entre dos fechas: es en 1489 cuando Álvaro, jaziendo doliente en cama de infirmidad corporal, hace testamento ${ }^{217}$, constituyendo el momento que podemos considerar como inicial; y, por otra parte, las exequias por el fallecimiento. Gracias al Libro de Recabdanças podemos confirmar la muerte en ese mismo año 1489. Así, en cuanto al tenente de A Rocha Forte y regidor compostelano, Álvaro Sánchez de Ávila, el espacio de la muerte se delimita por ambas márgenes con el testamento de 1489 y con las exequias, que podrían rondar, según la celebración de aniversario en la Catedral, el 28 de abril o 6 de septiembre ${ }^{218}$.

Desde un punto de vista metodológico debemos considerar los testamentos en una doble vertiente. Por una parte se trata de una manifestación en cierta forma política y

214 Religiosidad, que no religión, tomada, en definición de J. Caro Baroja, como la "facultad de practicar una religión dentro de las limitaciones individuales y sociales que le son impuestas a todo hombre al nacer”. Caro Baroja, J., Las formas de la vida religiosa. (Religión, sociedad y carácter en la España de los siglos XVI y XVII), Madrid, 1985, p. 29.

Influiría también la imagen, ofrecida desde la propia Iglesia y asentada en la mentalidad medieval, del inferno como grado máximo de sufrimiento y dolor, de tal forma que el testamento se revela como un medio para evitarlo.

215 Gómez Nieto, L., Ritos funerarios en el Madrid medieval, Madrid, 1991, p. 21-22.

216 Portela, Ermelindo; Pallares, M ${ }^{\mathrm{a}}$ del Carmen, "Los espacios de la muerte", en VV. AA., La idea y el sentimiento de la muerte en la historia y en el arte de la Edad Media, vol. II, Santiago de Compostela, 1992, p. 28.

217 AD, doc. 12. ACS, LD 5/1, fol. $1 r^{\circ}$.

218 AD, doc. 15. ACS, CF 13, fol. $16 \mathrm{r}^{\circ}$ y ACS, CF 13, fol. $33 v^{\circ}$. 
de interés económico, partiendo de la obrigatoriedad de testar impuesta por la Iglesia en el siglo XII, condición sine qua non para poder ser enterrado en territorio sagra$\mathrm{do}^{219}$. Así, desde la asunción popular de los principios de la religiosidad ya mencionados, la institución trataba de asegurarse una serie de beneficios y concesiones.

$\mathrm{Y}$ en segundo lugar el testamento es tomado como una escalera, quizá lenta y previa a la tortuosa purga de los pecados, pero una escalera, al fin y al cabo, hacia el Cielo. Las donaciones pías, centro fundamental de la política testamentaria medieval, adquieren forma de una especie de reciprocidad don-contradón en el terreno de la mentalidad, en la cual tras las concesiones, dádivas y mandas realizadas, la comunidad religiosa tendrá que corresponder con oraciones y plegarias que ayudasen en la salvación del fallecido. Misa de réquiem, procesiones, bendiciones, trintanarios, etc. pueblan las disposiciones testamentarias. De esta forma, Gómez Nieto, retomando una idea de Philippe Ariès, diferencia dos dimensiones dentro de la finalidad de los testamentos: las cláusulas piadosas; y el reparto hereditario ${ }^{220}$.

Introduciendo todo testamento, el viaje del cuerpo hacia su última morada carnal presenta ciertas particularidades. Los espacios, en plural, de la muerte se ven definidos y materializados en tres elementos o lugares: la casa, la iglesia y el cementerio $^{221}$. Acerca de la casa poco sabemos, nada en el caso de don Álvaro. Conocemos, como ya indicamos, una casa en la que vivía, en Santiago, en la Rúa da Moeda Vella, junto a San Martiño Pinario y, sin más indicaciones, podemos teorizar con que fue allí donde le sobrevino la enfermedad y la muerte.

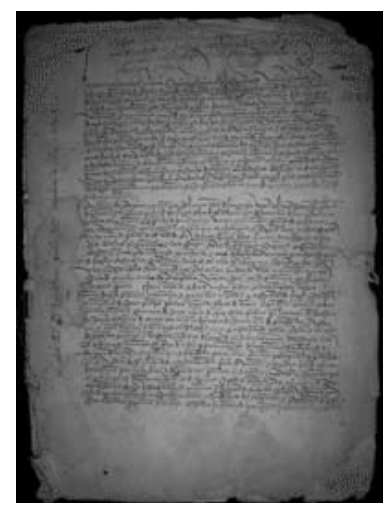

Testamento de Álvaro Sánchez de Ávila (1489).

Fuente: ACS, LD 5/1.

219 Gómez Nieto, L., Ritos, cit., p. 25.

220 Ibidem, p. 26.

221 Portela, Ermelindo; Pallares, M ${ }^{\text {a }}$ del Carmen, "Los espacios", cit., p. 29. 
El segundo espacio es la iglesia. La fundación de capillas donde recibir sepultura fue algo presente en la sociedad, en mayor o menor medida, desde los siglos centrales de la Edad Media hasta los siglos XVI y XVII. En el testamento de don Álvaro la disposición es clara: mando mi enterrar en el monesterio de San Payo d'Antaltares desta dicha çibdad de Santiago, en la capilla que yo fago, que ha de ser de vocaçion de Santa Maria de San, mi volcaçion (sic) ${ }^{222}$. Se trata de unas construcciones a las que se les atribuye además una función de templo para la celebración de ritos, en muchas ocasiones en favor del alma del difunto. En este sentido la información contenida en el testamento es parca, en comparación con otras mandas más profusas; nada dispone Álvaro acerca de su entierro, únicamente la petición de que, se hiciera como se hiciese, se reflejase su condición social: mando que el dia de mi enterramiento me fagan las exsequias e horras e digan las misas segund a mi estado pertenesçe $e^{223}$. Se mantiene aquí la percepción y conciencia nobiliaria que ya habíamos observado, deseando dar muestras de ella incluso tras su muerte. Contemplamos sin dificultad el macabro y cotidiano cuadro de un cortejo fúnebre, negras ropas y pasos ralentizados, portando un cuerpo hacia su última morada, pero de todas estas pinceladas ninguna es ofrecida por Álvaro Sánchez en su último documento.

Y conocemos también la localización exacta del tercer espacio, el cementerio, en este caso el sepulcro de don Álvaro: en la capilla de Santa María en la iglesia del monasterio de San Paio de Antealtares, a mano izquierda del altar; un lugar en el que, a pesar de las muchas obras que sufrió el templo en época moderna, podemos suponer que continúa descansando su cuerpo, a la espera de que alguna intervención arqueológica saque a la luz a un caballero medieval en todo su esplendor.

La nobleza bajomedieval gallega se diferencia claramente de la de los siglos centrales en lo que atañe a este tercer ámbito. En los siglos XII y XIII las preferencias se inclinaban por los monasterios rurales, tal y como ocurre en el caso de los Traba y los Ulloa, en el monasterio de Sobrado. Pero, en la segunda mitad del XIV y a lo largo del XV, la nueva nobleza escoge preferentemente las iglesias urbanas $^{224}$. Se ofrecen para ello diversas explicaciones, principalmente la atracción que las nuevas órdenes mendicantes ejercen sobre la nobleza, o la aproximación de ésta a los núcleos e intereses urbanos, tratando de controlar nuevos espacios de poder ${ }^{225}$.

222 AD, doc. 12. ACS, LD 5/1, fol. $1 r^{\circ}$.

$223 \mathrm{AD}$, doc. 12. ACS, LD 5/1, fol. $1 \mathrm{r}^{\circ}$.

224 Con preferencia, en muchos casos, por los templos de las órdenes mendicantes. Portela, Ermelindo; Pallares, $\mathrm{M}^{\mathrm{a}}$ del Carmen, "Los espacios", cit., p. 32.

225 Ibidem, p. 32. 
En lo que atañe a las disposiciones y fórmulas propias de los testamentos, según las reflexiones de algunos autores ya de principios de la modernidad, como Alejo de Venegas, los ejecutores de las mandas -unas de los personajes más importantes para el testador- debían de ser tres, de diferente condición y entre los que debía contarse por lo menos un cura ${ }^{226}$. En el caso de Álvaro Sánchez ésta es una disposición cumplida la rajatabla. Tres son los llamados conpridores de su testamento, y de ellos dos son canónigos: los honrrados Rui Peres e Juan Guedeja, canonigos de la santa ygllisia de Santiago, et el dicho Françisco Trebinno, regidor e vesino de la dicha çibdad de Santiago ${ }^{227}$.

Se trata, por lo general, de una persona muy próxima al testador y con importantes beneficios en las mandas concedidas. En este caso será don Francisco de Treviño el que se encargue de la celebración del aniversario por el fallecimiento de don Álvaro ${ }^{228}$.

Para comprender algunas de las disposiciones testamentarias ${ }^{229}$ es necesario tener en cuenta, nuevamente, las consideraciones de Leonor Gómez Nieto, autora para la que más importante que la hora de la muerte es el tiempo de la muerte, en el que tenemos que incluir además del momento del deceso todas las pompas y rituales posteriores, como vigilias, entierro, etc ${ }^{230}$.

En este sentido contamos con testimonios relativamente detallados acerca de lo que se debía de hacer tras la muerte del testador. Don Álvaro deja establecido que, una vez se produzca el fallecimiento, y tras la misa pertinente en el día del entierro, se oficien dos misas cada día durante los siete días siguientes, con sus correspondientes responsos; después, a los cuarenta días y en el aniversario, habrá de oficiarse otra igualmente con responso y con bendición de agua bendita sobre su sepultura, y que se digan en la capilla de Santa María o en el altar mayor, si ésta no estuviese terminada, precisión que nos indica que se encontraba todavía en construcción ${ }^{231}$.

Se materializaron tales disposiciones en la celebración de dos aniversarios, fundados en el templo compostelano por el compridor de su testamento, Francisco de

226 Nos referimos, en concreto, a Alejo de Venegas, con su Agonía del tránsito de la muerte, de 1537.

227 AD, doc. 12. ACS, LD 5/1, fol. 3ro.

228 AD, doc. 14. ACS, CF 13, fol. 16r'.

229 J. Coria Colino desgrana las mandas testamentarias organizándolas en: misas y aniversarios; ayudas a particulares; ayudas a obras pías; y ayudas a instituciones eclesiásticas, reparaciones de edificios, etc. Coria Colino, J., "El testamento como fuente de estudios sobre mentalidades (siglo XIII al XV)", en Miscelánea medieval murciana, vol. IX, Murcia, 1982, p. 200.

230 Gómez Nieto, L., Ritos, cit., p. 52.

231 AD, doc. 12. ACS, LD 5/1, fol. $1 r^{\circ}$. 
Treviño. Como vimos, en el Tumbo de Aniversarios de la Iglesia de Santiago se recoge la realización de los aniversarios en las fechas de 28 de abril ${ }^{232}$ y 6 de septiembre 233 , a pesar de que Álvaro pretendía que fuesen en 28 de diciembre y 15 de junio $^{234}$. En 18 de febrero de 1491 Francisco iguala ante del Cabildo el dinero destinado para ambas celebraciones, siendo la cuantía de cada una de 100 libras $^{235}$. Cada uno de ellos consistiría en una procesión que recorrería el camino por la plaza de la Quintana hasta el monasterio de San Paio de Antealtares y la capilla donde don Álvaro estaba enterrado ${ }^{236}$.

De esta forma, tal y como afirman Ermelindo Portela y María del Carmen Pallares, en los testamentos y en estas disposiciones "se manifiesta el deseo de prolongar -por medio de la solemnidad de las horas fúnebres [...]- más allá de la vida un status social de privilegio"237.

Se trata de buscar las suficientes oraciones para purgar los pecados, pidiendo por lo general que se ruegue por su alma; éste era un medio de limpiar el espíritu, no de corregir pero sí implorar perdón por las acciones que pudiesen perjudicarle en la otra vida y durante el Juicio al que, en algún momento, se habría de enfrentar. Y para esto toda ayuda era poca. Esta debió de ser también la motivación que llevó a don Álvaro a mandar que den de vestir a doze pobres sayas e lobas ${ }^{238}$, así como las múltiples concesiones a diversos centros religiosos, como la disposición de enviar a cada vna de las malatarias de Sant Lasaro e Santa Marta de arredor desta çibdad seysçientas partes de blancas a cada vna para çapatos e camisas e para los lazarados que en ellas estovieren ${ }^{239}$. Este tipo de cláusulas ha sido frecuente a lo largo de toda la historia medieval gallega, desde las donaciones para la fundación del monasterio de Sobrado por parte de los condes de Présaras, allá por el año $950^{240}$ hasta las donaciones de Álvaro Sánchez, pasando por casos como la dona-

232 AD, doc. 15. ACS, CF 13, fol. 16r ${ }^{\circ}$.

$233 \mathrm{AD}$, doc. 16. ACS, CF 12 , fol. $7 \mathrm{v}^{\circ}$.

${ }^{234}$ Et mando que mis complidores asenten de los aniversarios en mi fazienda en la yglisia de Santiago; et el vno se diga en dia de los Innoçentes de las ochavas de Navidad, e el otro que se diga a quinse dias del mes de junio. AD, doc. 12. ACS, LD 5/1, fol. $2 \mathrm{r}^{\circ}$.

235 Treviño busca dar, conçertar e ygualar a dinero los de los aniversarios que el alcalde de la Rocha, Alvaro Sanches, mandó. AD, doc. 14. ACS, IG 477, fol. 160r.

236 Fiat processio ad Quintani, apud ianua ipsius monasterii. AD, doc. 12. ACS, LD 5/1.

237 Portela, E.; Pallares, M. C., "Muerte y sociedad en la Galicia medieval (siglos XII-XIV)", en Anuario de Estudios Medievales, nº15, Barcelona, 1985, p. 200.

$238 \mathrm{AD}$, doc. 12. ACS, LD 5/1, fol. $1 \mathrm{r}^{\circ}$.

239 AD, doc. 12. ACS, LD 5/1, fol. $2 \mathrm{r}^{\circ}-\mathrm{v}^{\circ}$

240 Pallares Méndez, M. ${ }^{a}$ Carmen, El Monasterio de Sobrado: Un ejemplo del protagonismo monástico en la Galicia Medieval, A Coruña, 1979. 
ción del conde don Pedro de Lemos de las propiedades que había pertenecido a la orden del Temple en la tierra de Aveancos para el monasterio de Sancti Spiritus de Melide; en este último caso la donación se realiza sin un vínculo al fallecimiento del conde, aunque resulta ejemplificadora de una forma de piedad nobiliaria para con el estamento eclesiástico ${ }^{241}$.

Los servicios religiosos que dejó dispuestos don Álvaro, así como los que observamos en el testamento de su esposa, Inés García, no se incluyeron dentro de la cantidad de misas que se ordenaba fuesen rezadas por sus almas; el oficio a realizar a la semana del fallecimiento era algo usual, al uso de los aniversarios anuales. Algunas de las características principales de este tipo de celebraciones las encontramos aquí recogidas, fundamentalmente la misa solemne y la bendición con agua bendita ${ }^{242}$.

Podemos dividir los tipos de oficios en dos: los pagados de antemano, en efectivo; y los encargados por medio de mandas en las que se incluía la cesión de propiedades o rentas ${ }^{243}$. Ambos casos están presentes en los testamentos que aquí presentamos. Desde los siglos XII y XIII el papel del clero y la Iglesia en relación con el cadáver se refuerza por encima de familiares o compañeros, principalmente por medio de la misa, la encomendación y el cortejo o procesión. El cambio experimentado se centra en la mayor importancia del tiempo de la muerte sobre la propia hora mortis, destacándose como elemento simbólico; frente al protagonismo altomedieval del enterramiento ahora los elementos principales son el cortejo fúnebre y la procesión ${ }^{244}$. De hecho, la proliferación de las misas que debían de realizarse a la muerte de una persona y el hecho de cambiar el duelo en la propia sepultura y enterramiento por los oficios, llevan la Ariès a hablar de una "clericalización de la muerte"245.

Son fundamentalmente dos los aspectos que confluyen en las donaciones testamentarias: por una parte el de salvación, de una reafirmación en la propia fe y en la purga de los pecados cometidos para un más rápido disfrute de la vida eterna ${ }^{246}$; y

241 Sánchez Sánchez, Xosé M., Milites, cit., p. 27.

242 Ariès, Ph., El hombre, cit., p. 153.

243 Ibidem, p. 154.

${ }^{244}$ Ibidem, p. 143.

245 Ibidem, p. 157.

246 De esta manera, el chantre compostelano Pérez Corbacho, todavía en el siglo XIV, hace profesión de fe y reafirmación en la doctrina religiosa en su testamento -además de asumir su condición de pecador-, afirmando que creo todos os artigos de fe asi conmo os da nosa madre Santa Iglesia, et creo que Deus he todopoderoso et pode salvar a min et a todos los outros pecadores. Sánchez Sánchez, Xosé M., Estudio, cit., doc. 34. Asimismo, también D. Rodrigo de Moscoso se reafirma en todos los artículos de la fe católica.

Se refleja así el papel no sólo de reparto material, hereditario y de donaciones para favorecer el alma del difunto, sino incluso de una final y postrera profesión de fe cristiana. 
en segundo lugar la orientación de los bienes materiales, por medio de las referidas donaciones, para la salvación del espíritu.

Las donaciones no se componían únicamente de propiedades o dinero, sino también de un reparto de los bienes del difunto, como camas, libros breviarios, cálices o diversos elementos y objetos de uso cotidiana (sábanas, colchas, alabrancos, etc.). Son las que Philippe Ariès denomina "fundaciones de caridad"247, aunque sería mejor hablar de donaciones de caridad, ya que en estos casos no se concede, o por lo menos no siempre, el dinero para comprar algo sino el objeto en sí.

Para la edificación de su capilla en la iglesia de San Paio, y para el mantenimiento de dos capellanías perpetuas en ella, Don Álvaro dona los derechos de presentación de a meytad sencura de Sant Minno de Ares, et la quarta parte sencura del benefiçio de Santo Adraao de Corme, con mas la hermita de Santa Maria de Giestenla, que sea junto con el dicho beneficio de Corme, et mas la hermita que esta junto con la ygllisia de Ares de que yo soy padron [...], de la renta de lo qual todo ansy anexo ${ }^{248}$. Una serie de propiedades que, arrendadas, tanto ellas como los derechos de presentación, otorgarían unos ingresos suficientes para la obra y su cuidado y culto.

Tal conjunto trajo una serie de complicaciones al Cabildo, especialmente tras el fallecimiento de Francisco de Treviño, uno de los compridores del testamento, suponemos que el último. La presentación en las capellanías que establece estaba perfectamente reglamentada: ayan de estar perpetuamente dos capillans atitulados regiendo la dicha capellania [...]; los quales ayan de ser elegidos e apresentados quanto vacare, e ahora quando se estabelesçiere por mi herdero, et despues del por los cardenales mayores que fueren e por el que ahora es de la santa ygllisia de Santiago et por el abat que es o fuere del dicho monesterio ${ }^{249}$. Es decir, tal presentación se establecería, en primera instancia, por el heredero y después por los cardenales mayores del Cabildo, algo por lo que velarían los compridores.

Pero, la altura de 1511, en acta capitular de 16 de octubre, encontramos la resolución amigable de un pleito en la iglesia de Santiago precisamente sobre derecho de presentar de las capellanias que mando instituir el alcalde de la Rocha ${ }^{250}$. En este momento había fallecido ya Francisco de Treviño, pues los miembros del Cabildo actúan como como herederos de él ${ }^{251}$. El propio Álvaro Sánchez debió de

\footnotetext{
247 Ariès, Ph., El hombre, cit., p. 157.

248 AD, doc. 12. ACS, LD 5/1, fol. $1 \mathrm{r}^{\circ}$.

249 AD, doc. 12. ACS, LD 5/1, fol. $1 \mathrm{r}^{\circ}$.

250 ACS, IG 478, fol. $294 \mathrm{r}^{\circ}$.

251 ACS, IG 478, fol. 294ro.
} 
intuir la posibilidad de enfrentamientos, ya que en su propio testamento establece que se estos no se acordaren e fueren discordes en la apresentaçion, que se requiera mi herdero sufiçientemente ${ }^{252}$.

Los implicados deciden poner en manos del arcediano de Reina, del cardenal Diego Gutierres y del canónigo Gómez Ballo el arbitraje entre ellos y se comprometen a acatar la decisión que se tomase. Dicho pleito enfrentaba a la iglesia compostelana y Alvaro Nuñez y su muger, ya que el propio Cabildo le da permiso a los referidos mediadores, en 22 de noviembre de 1512, para que contaren y platiquen [...] sobre las diferençias que con ellos tienen sobre razon de las demandas que tienen puestas de la herencia del alcalde de la Rocha ${ }^{253}$. Poco después, en 24 de noviembre, se les concede la cantidad de 150 reales por los gastos de los testigos que traxieren y presentaren en este pleyto ${ }^{254}$. En este mismo día se nombra a los citadores de los testigos del pleito tanto para la ciudad de Santiago como para fuera de ella, así como a las personas que recibirían a dichos testigos ${ }^{255}$.

Un tardío y final recuerdo a don Álvaro, consecuencia de unas concesiones testamentarias que condujeron a una nueva lucha de poder, aunque sea a escala local, en una sociedad que sólo muy lentamente abandonaba el medievo.

Queda aquí patente la importante relación que mantenía don Álvaro con Francisco de Treviño. No sólo fue uno de sus compridores, ni quien fundó los dos aniversarios por su alma en la iglesia de Santiago, sino el tutor de la que era la última huella de su linaje que él conocería, su nieta Isabel Sánchez de Ávila, beliça.

Francisco de Treviño cumplió con su obligación hasta después de muerto. En 20 de diciembre de 1514, estando él ya fallecido, el Cabildo compostelano entrega a Álvaro Núñez los escritos y legados que Francisco había hecho para la que había sido su protegida, Isabel ${ }^{256}$.

Se nos muestran, con todo este conjunto de rasgos, diversos aspectos y prácticas que conforman una determinada concepción, forma y ritos de la muerte de la clase nobiliaria en la baja Edad Media, personificados nuevamente en la figura de Álvaro Sánchez de Ávila.

252 AD, doc. 12. ACS, LD 5/1, fol. $1 v^{\circ}$.

253 ACS, IG 478, fol. $382 v^{\circ}-383 r^{\circ}$.

254 ACS, IG 478, fol. $384 \mathrm{r}^{\circ}$.

255 ACS, IG 478, fol. $384 \mathrm{r}^{\circ}$.

256 AD, doc. 18. ACS, IG 479, fol. $72 v^{\circ}$. 


\section{CONCLUSIONES:}

Terminamos así este retrato analítico de uno de los principales personajes de la Galicia del siglo XV, en la transición de la baja Edad Media hacia la Modernidad: Álvaro Sánchez de Ávila. Al hilo del análisis de su vida y figura, hemos realizado un retrato de las estructuras nobiliarias fundamentales en la baja Edad Media gallega, con especial atención a la concepción linajística y relaciones de parentesco, a los recursos económicos y fundamentos de poder y a las mentalidades.

Se nuclean en torno a esta figura rasgos y aspectos característicos de la nobleza bajomedieval gallega que nos permiten tomarla como arquetipo y exponer, como hemos hecho, un completo análisis.

Una vida, la de Álvaro Sánchez, de la que tenemos conocimiento documental entre los años 1455 y 1489 y la cual presenta todavía algunos interrogantes, especialmente el de su origen, castellana o gallego, y el de los inicios de su vida. Nos inclinamos a considerar una procedencia castellana y una llegada a Compostela junto al arzobispo don Rodrigo de Luna, en la primera mitad del siglo XV.

Comprobamos la personalidad recia y quizá impulsiva de don Álvaro, marcada por la ostentación de un cargo que lo define para siempre: tenente de A Rocha Forte. Se erigió en adalid y defensor del arzobispado de Santiago, al que concebía como señor, al que hacía homenaje y al que debía auxilium, mostrado en diversas ocasiones: en la defensa de Rocha Forte, a lo largo de los años 50 y 60 de la centuria, en la participación de la batalla de Altamira, en 1471, y en la tenencia de la fortaleza de A Barreira en los años 80.

En el ámbito personal vivió dos matrimonios, uno con María González, con la que tuvo dos hijos, Gil Rodrígues Varela y Catalina Sánchez, y un segundo, hacia el año 1471, con Inés González, del cual ninguno de los dos guardó muy buen recuerdo. Trágico debió de ser el fallecimiento del su único hijo varón, Gil, además del propio dolor personal, en un momento en que la masculinidad y primogenitura resultaban fundamentales en los esquemas linajísticos y de parentesco.

Observamos en él la práctica de diversas fórmulas características en este momento a nivel peninsular para asegurar la obtención de recursos económicos y el fortalecimiento de su presencia en las esferas de poder: una política matrimonial orientada a vincularse con las oligarquías urbanas y la burguesía; una inversión en tierras y bienes inmuebles, para cuya posesión se vale de la influencia del arzobispo, lo cual derivó en enemistades con miembros del Cabildo; y una participación en la vida política de la ciudad, en este caso Compostela y con el cargo de regidor desde 1455. 
Cabalgando junto a su hermano, Pedro Sánchez, se concentran también en Álvaro valores militares -casi propios de los bellatores plenomedievales-, que conviven con una práctica de los malos usos del bajo medievo, siempre en favor de su señor, el prelado, y con Rocha Forte como centro neurálgico para controlar el abastecimiento (o desabastecimiento) de la ciudad.

Con A Rocha ya derribada, y tras la derrota de 1471 en la batalla de Altamira, continúa sirviendo a la prelatura como institución, haciendo aquello que mejor sabía hacer: dirigir con mano de hierro un castillo, el de A Barreira, principal enclave del Reino de Galicia tras la desaparición de A Rocha.

Y, en 1489, ya enfermo, hace testamento, quizá en su casa de la Rúa da Moeda Vella, en Santiago, donde vivía, tratando de poner sus asuntos en orden para enfrentarse a la muerte. No se olvida de los miembros de su casa, sus criados, sus amigos, de algunos de los cuales estaba criando los hijos, y sus herederos, dejando una buena herencia a su hija Catalina, que ya le había dado una nieta, Isabel Sánchez de Ávila. Nos muestra ella la parte más tierna del recio Álvaro Sánchez, cuando la llama cariñosamente Beliça.

Su morada final sería la capilla de Santa María que había ordenado construir en el monasterio de San Paio de Antealtares, donde, tras el suelo de piedra, suponemos que todavía descansa. Por algún tiempo Francisco de Treviño, compañero en el concejo compostelano, veló porque su recuerdo permanecerse vivo con la celebración de dos aniversarios, en 28 de abril y en 6 de septiembre, con una procesión hasta la sepultura que él mismo se encargó de dotar económicamente, como buen compridor de Álvaro, y cumplió con uno de los últimos deseos de su amigo: tutorar a su nieta, Isabel Sánchez de Ávila.

Una vida de caballo y espada, de nobleza y burguesía, de batalla. La vida de don Álvaro Sánchez de Ávila, teniente de A Rocha Forte, o la nobleza gallega medieval del siglo XV en la transición hacia la modernidad.

\section{BIBLIOGRAFÍA}

ARIÈS, Ph., El hombre ante la muerte, Madrid, 1984.

ARMAS CASTRO, José, Pontevedra en los siglos XII a XV. Configuración y desarrollo de una villa marinera en la Galicia medieval, Pontevedra, 1992.

BALIÑAS PÉREZ, Carlos, "O poder militar como elemento de afirmación social: o caso da nobreza altomedieval galega”, en VÁzQuez VArela, J. M. et al., A guerra en Galicia; o rural e o urbano na historia de Galicia, Santiago de Compostela, 1996, pp. 51-67. 
Beceiro Pita, Isabel; CÓRDOBA DE LA LLAVE, Ricardo, Parentesco, poder y mentalidad. La nobleza castellana siglos XII-XV, Madrid, 1990.

CALDERÓN ORTEGA, José Manuel, Álvaro de Luna: riqueza y poder en la Castilla del siglo XV, Madrid, 1998.

CARO BAROJA, J., Las formas de la vida religiosa. (Religión, sociedad y carácter en la España de los siglos XVI y XVII), Madrid, 1985.

CASTRILlO LAMAS, María de la Concepción, "Monarquía y nobleza en torno a la tenencia de fortalezas en Castilla durante los siglos XIII-XIV”, En la España medieval, nº 17, Madrid, 1994, pp. 95-112.

COUSELO BOUZAS, J., La guerra hermandina. Siglo XV, Santiago de Compostela, 1926.

DIAGO HERNANDO, Máximo, "Caballeros y hidalgos en la Extremadura castellana medieval (siglos XII-XV)", En la España medieval, nº 15, Madrid, 1992, pp. 31-62.

FERNÁNDEZ CONDE, Francisco J., La España de los siglos XIII al XV. Transformaciones del feudalismo tardío, Madrid, 2004.

FERNÁNDEZ DE VIANA Y VIEITES, José Ignacio, El tumbillo de San Bieito del Campo (Santiago), Granada, 1995.

GELABERT GONZÁLEZ, Juan Eloy, Santiago y la tierra de Santiago de 1500 a 1640, A Coruña, 1982.

GÓMEZ NIETO, L., Ritos funerarios en el Madrid medieval, Madrid, 1991.

GONZÁLEZ VÁZQUEZ, Marta, El arzobispo de Santiago: una instancia de poder en la Edad Media (1150-1400), A Coruña, 1996.

LÓPEZ CARREIRA, Anselmo, A cidade de Ourense no século XV. Sociedade urbana na Galicia baixomedieval, Ourense, 1998.

*LÓPEZ CARREIRA, Anselmo, "Os movementos sociais na Galiza medieval”, Murguía. Revista galega de Historia, n 9, xan.-abr., 2006, pp. 25-32.

LÓPEZ FERREIRO, A., Galicia en el último tercio del siglo XV, t. I, Santiago de Compostela, 1868.

*LÓPEZ FERREIRO, A., Don Rodrigo de Luna, Santiago de Compostela, 1884.

*LÓPEZ FERREIRO, A., "La Torre de la Barreira", Galicia Histórica, t. I, Santiago de Compostela, 1901, pp. 35-38.

*LÓPEZ FERreIRO, A., Historia de la Santa A. M. Iglesia de Santiago, t. VII, Santiago de Compostela, 1905.

MATOSSO, J., Identificação de um pais: ensaio sobre as origens de Portugal. 1096-1325, Lisboa, vol. II, vols., 1986-1988.

MORENO NÚÑEZ, José Ignacio, "Los Dávila, linaje de caballeros abulenses. Contribución al estudio de la nobleza castellana en la Baja Edad Media", en Estudios en memoria del profesor D. Salvador de Moxó, vol. II, Madrid, 1982, pp. 157-172.

NIETO SORIA, José Manuel, "Enrique IV de Castilla y el Pontificado (1454-1474)", En la España medieval, $\mathrm{n}^{\circ}$ 19, Madrid, 1996, pp. 167-238. 
NOVÁS PÉREZ, M. ${ }^{a}$ Elena, Catálogo de la Colección de Tomos de Varia (Primera Serie) del Archivo-Biblioteca de la Catedral de Santiago, Santiago de Compostela, 2006, inédito.

OLIVERA SERRANO, César, "La Galicia de Vasco de Aponte: los pleitos del arzobispo Tabera contra los linajes de la tierra de Santiago", En la España medieval, n 22, Madrid, 1999, pp. 285-315.

* OLIVERA SERRANO, César, El ocaso de las fortalezas compostelanas. Visitas y tasaciones (15351547), Santiago de Compostela, 2000.

PALLARES MÉNDEZ, M. ${ }^{a}$ Carmen, El Monasterio de Sobrado: Un ejemplo del protagonismo monástico en la Galicia Medieval, A Coruña, 1979.

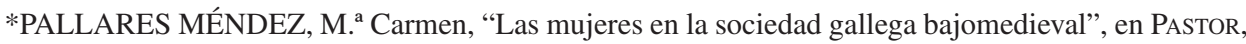
Reyna (comp), Relaciones de poder, de producción y parentesco en la Edad Media y Moderna, Madrid, 1990, pp. 351-373.

*PALLARES, María del Carmen; PORTELA, Ermelindo, "Aristocracia y sistema de parentesco en la Galicia de los siglos centrales de la Edad Media. El grupo de los Traba", Hispania. Revista española de historia, vol. LIII, 185, 1993, pp. 823-840.

*PALLARES, $\mathrm{M}^{\mathrm{a}}$ Carmen; PORTELA, Ermelindo, "Compostela y la revuelta irmandiña", Universitas. Homenaje a Antonio Eiras Roel, t. I, Santiago de Compostela, 2002, pp. 89-110.

*PALlARES, $\mathrm{M}^{\mathrm{a}}$ Carmen; PORTELA, Ermelindo, "Reis, bispos e burgueses", cap. de Portela, Ermelindo (coord.), Historia da cidade de Santiago de Compostela, Santiago de Compostela, 2003, pp. 123-167.

PARDO DE GUEVARA Y VALDÉS, Eduardo, Los señores de Galicia, 2 vols., A Coruña, 2000.

PAREDES MIRÁS, $\mathrm{M}^{\mathrm{a}}$ del Pilar, Mentalidade nobiliaria e nobreza galega. Ideal e realidade na Baixa Idade Media, A Coruña, 2002.

PÉREZ RODRÍGUEZ, Francisco Javier, El dominio del Cabildo Catedral de Santiago de Compostela en la Edad Media (siglos XII-XIV), Santiago de Compostela, 1994.

*PÉREZ RODRÍGUEZ, Francisco Javier, La Iglesia de Santiago de Compostela en la Edad Media, el cabildo catedralicio (1100-1400), Santiago de Compostela, 1996.

PIFERRER, Pablo, España: sus monumentos y artes, su naturaleza y historia, Barcelona, 1884.

PORTELA, E.; PALLARES, M. C., "Muerte y sociedad en la Galicia medieval (siglos XII-XIV)”, en Anuario de Estudios Medievales, n¹5, Barcelona, 1985, pp. 189-202.

*PORTELA, Ermelindo; PALLARES, Ma del Carmen, "Los espacios de la muerte", en VV. AA., La idea y el sentimiento de la muerte en la historia y en el arte de la Edad Media, vol. II, Santiago de Compostela, 1992, pp. 27-35.

*PORTELA, Ermelindo; PALLARES, M. ${ }^{a}$ Carmen, "De Gelmírez a los irmandiños. Conflictos sociales en la ciudad de Santiago", El Camino de Santiago: Estudios sobre la peregrinación y sociedad, Madrid, 2000, pp. 107-131.

*PORTElA, Ermelindo; PAlLARES, Ma Carmen; SÁnchez, Xosé M., Rocha Forte. El castillo y su historia, Santiago de Compostela, 2004.

PORTELA PAZOS, Salustiano, Galicia en tiempo de los Fonsecas, Madrid, 1957. 
RODRÍGUEZ GONZÁLEZ, Ángel, Libro del Concello de Santiago (1416-1422), Santiago de Compostela, 1992.

QUINTANILLA RASO, María Concepción, "La tenencia de fortalezas en Castilla durante la baja Edad Media", En la España medieval, n 5, Madrid, 1986, pp. 861-895.

RUÍZ, Teófilo, Historia social de España. 1400-1600, Barcelona, 2002, p. 207.

SÁNCHEZ CHOUZA, José Manuel, A Coruña en la baja Edad Media, A Coruña, 2005.

SÁNCHEZ SÁNCHEZ, Xosé M., Estudio y transcripción de la carpeta $n^{\circ} 13$ de Documentos Particulares del Archivo Catedralicio de Santiago, tesis de licenciatura inédita, Santiago de Compostela, 2000.

*SÁNCHEZ SÁNCHEZ, Xosé M., "Unha primera pedra: documentación inédita de San Xusto de Toxosoutos”, Compostellanum, vol. XLVII, n 3 y 4, Santiago de Compostela, 2002, pp. 413-437.

*SÁNCHEZ SÁNCHEZ, Xosé M., "Castrizán: a fortaleza vixiante do sur. 1477-1478/79”, Seminario de Estudios Redondeláns, $\mathrm{n}^{\circ}$ 2, Redondela, 2005, pp. 63-93.

*SÁNCHEZ SÁNCHEZ, Xosé M., Milites Templi: A Orde do Temple na vila de Melide, A Coruña, 2006.

*SÁNCHEZ SÁNCHEZ, Xosé M., "La fortaleza de Rocha Forte. Un castillo concéntrico en las corrientes constructivas europeas del siglo XIV”, Compostellanum, vol. LII, n 3-4 (2007), pp. 603631.

*SÁNCHEZ SÁNCHEZ, Xosé M., "The fortress of Rocha Forte and European military building trends. A concentric castle (14th century)", British Archaeological Reports International Series, Oxford, 2009, pp. 53-65.

SER QUIJANO, Gregorio del (coord.), Historia de Ávila. Edad Media (siglos XIV-XV), Ávila, 2006.

VÁZQUEZ BERTOMEU, Mercedes, La hacienda azobispal compostelana. Libros de Recaudación (1481-1483 y 1486-1491), Santiago de Compostela, 2002.

*VÁZQUEZ BERTOMEU, Mercedes, "La iglesia de Santiago hacia 1500: el Libro I de Subsidio", Compostellanum, vol. LXVII (2002), pp. 439-486. 


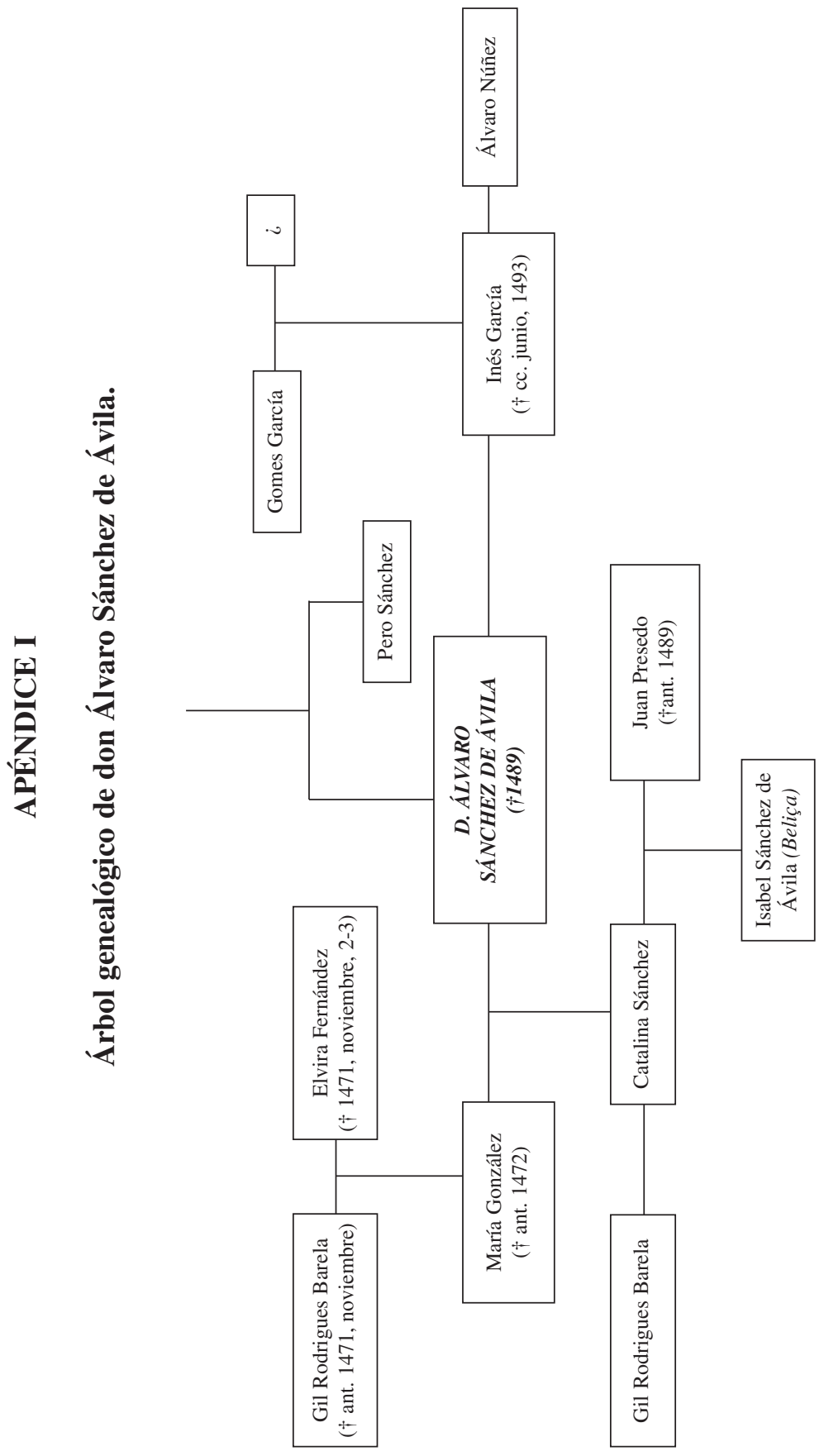




\section{APÉNDICE II \\ APÉNDICE DOCUMENTAL}

\section{1}

1455, diciembre, 5. Santiago de Compostela.

Foro del deán y Cabildo de la Iglesia de Santiago a don Álvaro Sánchez de Ávila, alcaide de A Rocha Forte y regidor compostelano, del coto y heredades de San Pedro de Viños, San Martiño de Calvos y Santiso de Calvos, por pensión anual de 500 maravedies viejos.

B.- ACS, S 16/13. Pergamino. 36,3x47,8 cm.

Sabean quantos este publico instromento rafitiotico (sic) viren conmo nos, Gomes Fernandes, cardeal enna santa igllisia de Santiago de Conpostela et vicario ennoa abtos capitulares, da dita igllisia, [et] as outras presonas (sic), dignidades, canoigos et benefiçiados deles que ende a o presente quiseron et poderon seer presentes, conven a saber don Afonso Sanches de Avila, chantre enna dita igllisia et don Afonso Lopes de Valladolid, dean de Outes et arçediano de Salnes, et Françisco Rodrigues de Toledo, mestre escola, et Thedorico, cardeal mayor, et Martin Lopes, Afonso Eanes da Crunna et Gonçal de Morraço, cardeaas, et Estevon Fernandes, thesoureiro, et Fernan Rodrigues de Leva, juiz de Vellestro, et Nuno Peres de Soutomayor, juiz de Luou, et Jacome Sanchez de Canas, Diego Rodrigues de Carvallido, Fernan Peres de Regna, arçipreste Moya (sic), Lopo Rodrigues, Vaasco Martinez, bachiller, Pero Lopes de Segovia, Afonso de Sevilla, Mino Fernandes de Olmedo, Afonso de Moya, Gonçal de Vaamonde, Juan de la Parra, Afonso del Sello, Fernan da Crunna, Loys de Cifontes, Juan Garçia, Juan Fernandes de Briallos, Diego de Samanego, Alvaro ***eira ${ }^{257}$, Gomes de Vaamonde, canonigos enna dita igllisia, seendo juntados en noso cabildo capitularmente enna torre nova por tanjemento de canpaa, segund que avemos de vso et de costume, et avido primeiramente por moytas vezes en outros cabildos pasa ${ }^{* * * 258}$ do contrabto infraescripto, noso acordo con deliberaçion et deligente trabtado et veendo et entendendo [d]e conmo esto aqui adeante contiudo he en prol, probeito et vtilidade noso et de nosos suçesores et dos beens et posisoos perteesçentes a a mesa capitular. Por ende, nos, por nos et por nosos suçesores que despois de nos vieren, de consintimento et

257 Tres o cuatro letras.

258 Cuatro o cinco letras. 
outorgamento do dito Vaasco Martinez, bachiller noso concanonigo et teençeiro da Teença Grande, que presente esta et consente eno adeante contiudo, outorgamos et conosçemos que por este dito publico instromento aforamos et damos en aforamento et por razon de foro rafitiotico, d'oje este dia en adeante, a vos Alvaro Sanches, alcayde da Rocha Forte de Santiago et rejedor que sodes da çibdade de Santiago, que presente sodes con nos et con dito cabildo, por todo tenpo de vosa vida et da primeira moller que ouberdes et con que casardes, et solenizardes casamento et desposorio por vos feito et outorgado et por mays tenpo de [hua] voz despois do pasamento da vida de vos, o dito Alvaro Sanches, a qual dita voz queremos et outorgamos que vos o dito Alvaro Sanches, en vosa vida et soude, ou a o tenpo de voso finamento, posades nomear e nomeedes a tal vos; et no seendo así, por vos nomeyada, que seja voz deste dito aforamento aquel que de dereito ouver de aver et herdar vosos bees ou a mayor parte deles.

Conven a saber que vos aforamos et damos en este dito aforamento po lo dito tenpo de vidas et voz, segun, dito he, con consintimento et outorgamento do dito noso teençeiro, o cauto de San Pedro de Vinoos con todo seu sennor[io] et herdades, con eso meesmo San Martino de Calvos de So Caminno et Santiso de Cornado, con todo o sennorio et herdades perteesçentes a o dito Cabildo et teenç[eiro] con mays a quarta parte do couto d'Oiiz, sennorio et herdades perteesçentes a o dito Cabildo con os casares et herdades que perteesçeu a a dita teença que agora ten forçado et tomado Alvaro Pulleiro con, outrosi, o casal de Parente açerca de Arzua, et con o casal de Sebeo et segund que o dito noso Cabildo suya de teer, posuyr et levar en nome da dita teença Gonçal Sanches, alcalde que foy da dita çibdade.

$\mathrm{O}$ qual vos asi todo aforamos conmo dito he, con estas condiçoos et non sen elas. Primeiramente que vos, o dito Alvaro Sanches, por vosas custas et expensas propias saquedes todas las posisoos et herdamentos, casas, casares et chantados a ditos coutos perteesçentes por inventario et per (sic) ante notario publico et dedes delo a o dito Cabildo vn tunbo novo sinado de escrivano publico das ditas posisoos, çerca do qual traballedes et façades todas deligençias que poderdes por sacar et $[\ldots ..] \operatorname{sacad}[\ldots]$ no $^{259}$ dito Cabildo et Teença Grande os tres casares de herdades que Alvaro Pulleiro, escudeiro, ten subtraydos, vsurpados et tomados a a dita Teença Grande, que soya de andar con os ditos coutos, os quaes casares son çerca de torre de Medin. Iten que eso mismo apartades et façades apartar o quarto dos casales et sennorio do couto d'Oviiz( $(\dot{)})$ para o dito Cabildo et Teença Grande. Iten que a tal vos que asi por vos for nomeada, que seja fillo ou filla, neto ou neta voso se o ouver-

259 Dos o tres letras. 
des et teverdes a o tenpo de voso finamento da dita vosa moller, et non o avendo ende que a tal voz asi por vos nomeada seja tal presona et semellabele de vos ou de menos estado, et se for nomeada de mayor estado que vos seja ome ou muller poderosos et tal que vos et vosos suçesores et o teençeiro da dita teença non posa aver et cobrar del ou dela a tal pension de foro boamente, que a tal nominaçion lasi/ por vos feita seja en si ninhuna et de nivn valor et que posa viinir et vena a o dito Cabildo et teençeiro da dita teença se enbargo deste foro. Iten que vos eso mesmo, o dito Alvaro Sanches, en quanto asi fordes foreiro, inquilino et teendor da dita igllisia, gardedes todo onor a os benefiçiados dela et a os seus familiares, criados et paniguados et a cada vn singularmente, que non façades nen consintades fazer mal nen dano, injuria nen outro desaguisado algun a dita mesa capitular nen a as presonas et benefiçiados dela nen a seus criados et paniguados nen a seu vasalos et [..]sei$\operatorname{ros}^{260}$ nen eso mesmo a os bees, herdades et posisoos d[el et de] cada vn deles, asi das cousas propias suas deles et de cada vn deles conmo das que teen por teenças et por bene[fiç]ios ou por prestemonios ou en outra qual quer maneira; et se acaesçer, o que Deus non $[\ldots]^{261}$, que vos, o dito Alvaro Sanches fezerdes ou mandardes [ou] ***tirdes ${ }^{262}$ fazer algún agraveo ou injuria a os ditos benefiçiados ou qualquer deles en qualer maneira que sejades tiudo et obligado seendo vos chamado para cabildo sobre las ditas cousas et en cada huna delas, que venades a el et estedes a mandamento de dous benefiçiados, segun a forma et thenor das coostituyçoos da dita igllisia; et non o querendo vos asi fazer que vos [... $]^{263}$ vos cayades et ajades caydo ennas penas en que cayen aqueles que non son obidientes a a igllisia et van contra ela. Por lo qual dito aforamento vos, o dito Alvaro Sanches et vosa moller, en vosas vidas et soudes, dedes et paguedes de foro et pension anuatin de cada ano catroçentos maravedis de moeda vellapor cada dia de Nadal na Nasçença de Deus en casa do dito teençeiro, et a dita vos despoys de vos et a dita vosa moller de et page de cada vn anno de foro quinientos maravedis da dita moeda por lo dito dia de Nadal. Et sen desconto da dita penson (sic) de foro vos, o dito Alvaro Sanches, et a tal vosa moller et a dita vos, por vosas custas et expensas propias, devedes et avedes de reparar et perfeitar et teer reparados et perfeitados os casaes et herdades que vos asi aforamos et asi os leixar reparados et perfeitados conprido o tenpo deste aforamento, con todo o bon perfeito et reparo que en el for et estever feito, et non devedes de vender, sopenorar, alleanar, trocar, poer nen traspasar este

260 Dos letras.

261 Palabra de tres o cuatro letras.

262 Dos o tres letras.

263 Palabra de cuatro o cinco letras. 
dito aforamento en outra presona sen noso consintimento ou de nosos suçesores, et avendoo de fazer que o façades a nos ou a eles tanto por tanto conmo outro algun por el queira dar ou prometer querendoo nos ou eles, et non o querendo que en ton o posades fazer et façades a a tal presona que non seja escudeiro nen cavaleiro nen dona nen outro ome poderoso, et que seja semellavele de vos ou de menor condiçon, et tal que de et page (sic) de cada vn anno a dita penson de foro et que faça, cunpla et agarde todas las outras maneiras et condiçoos aqui contiudas et declaradas; et fazendo delo o contrario que non valla et descayades et ajades descaydo deste dito aforamento. Et he nosa voontade que non pergades este dito aforamento nen descayades del caso que çasedes por dous ou tres annos de pagar esta dita penson et trebuto se despois conprirdes toda a piga antes que por nos et por nosos suçesores vos seja movido pleito por vos quitar este dito foro por lo aver çesado de pagar o despois de movido ante de sentençia defenitiva (sic). Et asimesmo he nosa voontade que, caso que contra a forma susodita oubesedes feito algun contrabto de venda, aliaçon ou traspasaçon deste foro, non descayades si ante que por nos ou por nosos suçesores vos aja movido pleito para vos lo quitar ou despois, ante da sentença defenitiva redemiedes a tal venda, alienaçon ou transpasaçom et tornardes a vos et recobrardes o dito foro. Et conprindo et agardando vos, o dito Alvaro Sanches, et vosa moller et a tal voz todo o sobredito et (sic) nos nen nosos suçesores non vos devemos de tirar, quitar nen tollir nen quitaremos nen tolleremos este dito aforamento durante o tenpo del por mays penson de foro nen menos, nen por al tanto que outro algun por elo non queira dar ou prometer, nen por dizeremos et alegaremos que en elo oube $<r>$ enganno nen por outra razon nen contradiçon alguna; antes queremos et outorgamos, por nos et por nosos suçesores, de vos teeremos, conpriremos et agardaremos todo o sobre dito, et vos non yr nen pasar contra elo nen contra qualquer cousa et parte delo.

Et eu, o dito Alvaro Sanches, que presente soo, por min, et para a dita minna moller et voz, asi o outorgo, et reçebo todo o sobre dito segun dito he, et obligo meus et seus bees mobeles et raizes, presentes et futuros, que eu et eles demos et pagemos de cada vn anno a dita penson de foro, segundo dito he, et que façamos, cunplamos et agardemos todas las outras maneiras et condiçoos de suso contiudas et declaradas.

Et de mais nos, as ditas partes et cada huna delas, por nos et por nosos suçesores, queremos et outorgamos que qualquer de nos ou deles que contra esto que dito he ou contra qualquer cousa et parte delo for ou pasar, en parte ou en todo et ho asi non tener, conprir et agardar, que peite et page de pena a parte de nos ou deles que o agardar et conprir dozentas dobras d'ouro castellanas, para o qual todo o sobre dito nos, os ditos benefiçiados obligamos tos los bees da mesa capitular, et eu, o 
dito Alvaro Sanches, obligo a min mesmo et todos meus bees, avidos et por aver. Et a pena, pagada ou non pagada, todavia este contrabto de aforamento et todo o contiudo en el fique et valla en seu rebor, que foy.

Feito et outorgado et pasou asi enno dito cabildo conmo dito he a çinco dias do mes de dezembro do ano do Nasçemento de Noso Sennor Ihesu Christo de mill et quatroçentos et çinquenta et çinco annos, estando presentes por testigos os sobreditos Afonso Sanches de Avila, chantre, et Martin Lopes, Gonçal de Morraço, cardeaas, et os ditos Diego Rodrigues et Afonso de Sevilla et Juan de Toledo, coengos.

$\mathrm{Eu}$, Alvaro de Casteenda, notario publico jurado de Santiago, por la igllisia de Santiago, este sobre dito contrabto de aforamento saquey das notas (signo) e registros que pasaron por ante Jacome Eanes, notario apostolico et escusador de Juan de Casteenda, coengo de Santiago et notario, que fuy meu antesçesor, $\mathrm{pa}<\mathrm{ra}>$ as quaes notas sacar, reduzir et tomar en esta publica forma eu ey poder et abtoridade de noso señor don Rodrigo de Luna, arçobispo da Santa igllisia et arçobispado; o qual dito contrabto de aforamento tomey et reduzi en esta publica forma a pedimento de Alvaro Sanches, alcayde da Rocha Forte de Santiago por lo dito sennor arçobispo et regedor da çibdade de Santiago, que me demandou para guarda e conservaçion de seu dereito. Et por ende puje aqui meu nome et signo que tal he en testimoyo de verdade.

1459, julio, 11. Santiago de Compostela.

Fragmento del testamento de García, escudero del conde de Trastámara don Pedro Álvarez Osorio, haciendo mención a Álvaro Sánchez de Ávila y a su hermano, Pedro Sánchez, en referencia al robo de un caballo.

A.- ACS, $699 \mathrm{AB}$, fol. $194 \mathrm{r}^{\circ}$.

Item por quanto eu tomey e prendin a Pero Sanches, yrmaao de Alvaro Sanchez, alcalde da Rocha e o tiven preso por çertas feridas que me $\mathrm{g}[\ldots]^{264}$ deu e por un caval[o] que me tomou, que a a sazón bynia con o sennor arçobispo de Santiago e o defendia, sen me faser conprimento de justiçia; o qual dito Pero Sanches, e o dito Alvaro Sanches en seu nome, me deu en satisfaçion do sobredito hua cadea d'ouro que pesav[a] sasenta reales, a qual eu vendi a Roy Xordo, escudeiro, que Deus aia.

264 Una o dos palabras. 
1461, julio, 17. Santiago de Compostela.

Aceptación del foro de las propiedades de la Tenencia Grande del Cabildo compostelano a don Álvaro Sánchez de Ávila tras la recusación del tenenciero, Vasco Martínez, del primeir foro y contrato firmado, deshaciendo cualquier acto realizado contra dicho foro.

B.- ACS, S 16/13. Pergamino.

Anno do nasçemento de Noso Sennor Ihesu Christo de mill et quatroçentos et seseenta et huun annos, a dez et sete dias do mes de julio, este dia, en Quintaa de Paaços, çemiterio, plaça publica da çidade de Santiago, et estando ende presentes o bachiller Vaasco Martines, canonigo da dita igllisia et teençeyro da Teença Grande por lo Cabildo da dita igllisia, et Alvaro Sanches, regedor da dita çibdade, alcalde da Rocha Forte de Santiago et en presença de min, Alvaro de Casteenda, notario sobredito et testigos a juso scriptos, logo o dito bachiller Vasco Martines diso que por quanto el avia feyto et fezera çertos autos para desfazer et contradizer o dito contracto segund que mais conpridamente pasara por ante min, o dito notario, por ende que el en[...]provado ${ }^{265} \mathrm{o}$ dito contracto et avendoo por firme, segund et enna maneira que en el se contiña et era contiudo, se partia et parteu, et demitia et demeteu de todos et quaesquer actos et pedimentos et quaesquer cousas que en contrario do dito contracto fezera et ouvese feyto ante quaesquer personas, para que non fezesen en pleito nen fora del, et los dava et dio por ningunos. Et asi, conmo teençeiro da dita teença aprovava et reteficava et aprobou et consenteu enno sobredito contracto de foro et ho outorgava et outorgou outra vez de novo si et en quanto fose compl ${ }^{* * * 266}$ dito Alvaro Sanches et a as personas en el contiudas, et promete(i) et prometeu de non yr nen passar contra el en parte nen en todo, so a pena et penas en el contiudas et so obligaçon de si et de seus bees eclesiasticos et seglares que para elo obligava et obligou, et que todavia a pena p[agad]a ou non o dito contracto fose firme et valuese e quanto que en el se contina et era contiudo.

Et o dito Alvaro Sanches, regedor et alcalde, diso que asi a reçebia et reçebeu, et pedeu a min, o dito notario, que llo dese asi signado, et a os presentes rogou que fosen delo testigos.

Presentes a elo por testigos Fernan Rodrigues de las Navas, cardeal de Santiago e Vaasco Borrallo, mercader, Jacome do Vilas, raçoeyro de Sancti Spiritus enna dita igllisia, moradores enna dita çibdade, e outros.

265 Das letras.

266 Seis o siete letras en una o dos palabras. 
Eu, Alvaro de Casteenda, notario publico jurado de Santiago por la igllisia de Santiago [a todo esto que] dito he $[. . .]^{267}$ con os ditos testigos presente (signo) ***268 quando o dito bachiller Vaasco Martines, canonigo e teesçeiro, aprovou o dito contrabto e retificou $[\ldots]^{269}$ cousas que ditas son enna sobredita retificaçion, e huno(i) con os ditos testigos presente fuy e fis scripvir, e por ende puje aqui meu nome e signo, que tal he, en testimonio de verdade.

Al dorso: Presentados antel bachiller Gonçalo de Jahen por Alvaro Sanches de Avila. Testigos Antonio de Vaamonde e Pero Pres***270.

\section{4}

1463.

Referencias a las posesiones del alcaide de A Rocha, don Álvaro Sánchez de Ávila, en los cotos de Oíns, Calvos y Santiso de la Tenencia Grande, en el Libro III de Tenencias; se refiere cómo los había conseguido y como los mantenía, en perjuicio de la Iglesia de Santiago.

ACS, CF 16, fols. Vv ${ }^{\circ}$, VIIIv'-IXr .

\section{(fol. $\mathrm{Vv}^{\circ}$ ) Enno couto d'Oiins.}

Iten ha mays esta teença o quarto do sennorio do couto de Oyns, et o quarto de todas las herdades que enno dito couto pertesçen a o sennorio, segundo que anda sobre sy divisadas et cognosçidas por do sennorio; pero este quarto et herdades del esta misto con os outros tres quartos de sennorio. Dizen os que ende moran que poden viver con cada huun dos sennores do dito couto qual quiseren, mays non con outro de fora. As herdades renderan cada anno quasy çen maravedis. Ten esto en foro agora Alvaro Sanches, alcayde de Rocha, con outros coutos. Vt infra dicetur.

[En nota posterior: Este coto d'Oyns, con los cotos de Calvos y Santiso et todo lo mas que esta Tenençia Grande tenia en ellos, como lo tenia el alcalde de la Rocha, y otras heredades que el dicho alcalde tenia en fuero, se desmembro desta tenençia y se hizo tenençia nueba, la qual se dio en pregons(i) al chantre don Juan Melgarejo, segund esta en el libro del procuratorio.]

$[\ldots] /$

267 Palabra de seis o siete letras.

268 Palabra de tres o cuatro letras.

269 Palabra de cuatro o cinco letras.

270 Se interrumpe la línea por un fragmento de papel pegado en el pergameo a modo de refuerrzo. 
(fol. VIIIv ${ }^{\circ}$ ) Coutos de Calvos et Santisso.

Iten ennos coutos de Calvos er de Santiso de Cornado avera quasy triinta homees de sennorio, toda a juridiçion, mera et mixta, da dita tennça en tempo do arçediano, meu anteçesor ${ }^{271}$, davanlle de serviço os moradores do dito couto todos huna duzia de carneiros et huun par de vacas, et de cada casa huun par de gallinas, et as outras dereyturas que ende ha como en coutos, penas et colleytios.

Estes coutos ten en foro Alvaro Sanches de Avila, alcayde que agora he da Rocha Forte de Santiago ${ }^{272}$. Ouveos con roos et favores do sennor arçobispo don Rodrigo de Luna, con quen el vivia, et con grande privança, por quatroçentos maravedis, os quaes valen ben, segund que os el ten de cada anno, mill et seysçentos maravedis vellos. Et eu quiserallos quitar des que morreo o arçobispo, porque me davan por eles mill \moravedis de cada anno et mays de calças/ et huna mula de quoreenta dobras, et Fernan de Fonseca mandoume / (fol. IXro ${ }^{\circ}$ que o non fezese, quasy cominando de parte de noso sennor arçobispo don Afonso.

Asy as ten en grande fraude et danno da teença, et por huna escriptura fabricada que fezo et notou Jacome Yanes.

\section{5}

1463, agosto, 25-1464, agosto, 5. Santiago de Compostela.

Renovación del pleito y homenaje de don Álvaro Sánchez de Ávila, casteleiro y alcaide del castillo de Rocha Forte, en el momento de renovación de prelado al frente de la sese compostelana de Alonso de Fonseca I a Alonso de Fonseca II. Se incluye: pleito de homenaje de don Álvaro como tenente de la Rocha a don Alonso de Fonseca I (1463, agosto, 25. Santiago de Compostela); y la petición del mismo don Alonso de Fonseca I, siendo ya arzobispo de Sevilla, a don Álvaro, de la devolución al prelado actual don Alonso de Fonseca II de la posesión de la fortaleza, devolviendo a don Álvaro Sánchez el homenaje realizado y pidiéndole que lo renueve con el nuevo arzobispo (1464, agosto 5. Béjar).

B.- ACS, IG 702, fol. $302 r^{\circ}$ inv-299r inv. En el pleito se inlúyen también, a continuación, las escrituras correspondientes a don Gonzalo de Figueroa, alcaide del castillo de Xallas.

Ed.- Portela, Ermelindo; Pallares, Ma Carmen; Sánchez, Xosé M., Rocha Forte. El Castillo y su historia, Santiago de Compostela, 2004, doc. 5, pp. 96-100.

${ }^{271}$ Era tenceiro da Tenza Grande, neste momento, o bacharel e cóengo Vasco Martíns. ACS, CF 16, fol. $\mathrm{Ir}^{\circ}$.

272 Á márxe: nota et male. 
(fol. $302 r^{\circ}$ ) En la torre nueva de los palaçios arçobispales que son dentro de la çibdad de Santiago, donde poso el muy reverendo sennor don Alfonso de Fonseca el moço, arçobispo de Santiago, e en presençia de min, el notario e testigos que a yuso seran escriptos, estando presentes Alvaro Sanches de Avila, alcalde de la Rocha Fuerte de Santiago, e Gonçalo de Figeroa, alcayde del castillo de Jallas, el dicho reverendo sennor arçobispo, presento e leer fiso por min, el dicho notario, a los dichos Alvaro Sanches e Gonçalo de Figeyroa, dos cartas patentes del mui reverendo sennor don Alfonso de Fonseca el viejo, arçobispo de Sevilla, firmadas de su nombre e selladas con su sello, e otras dos escripturas de pleitos e omenajees signadas del signo e suscriçion de Juan de Arevalo, escripvano de camara del rey nuestro sennor, las quales cartas e escripturas non era risas $(i)$ nin cançeladas nin en otra parte sospechosas, antes caresçientes de todo viçio e error, segund que suponia raçon por elas e cada vna dellas paresçia, de las quales, vnas en pos de otras, sus thenores son los seguientes:

Don Alfonso de Fonseca, por la miseraçion devina arçobispo de Sevilla, oydor de la abdiençia del Rey nuestro sennor e del su consejo, por la presente mandamos a vos, Alvaro Sanches d'Avila, alcalde de la Rocha Fuerte, casa et fortoleza de la igllesia e arçobispado de Santiago, que acudades et entregedes et fagades acudir e entregar esa dicha casa e fortoleza que por nos tenedes et que de vos confiamos al muy reverendo in Christo padre e sennor don Alfonso de Fonseca, arçobispo de Santiago, nuestro sobrino, o a quen su poder oviere bien e conplidamente. Et lo reçebades en ella en lo alto et en lo baxo, con pocos e con muchos, de dia o de noche, por la forma e manera et conmo a nos acudiriades e reçeberiades en ella et nos la dariades et entregariades et nos sodes obligado a nos la dar et entregar por quanto el dicho sennor arçobispo nuestro sobrino et proveydo de la dicha igllesia et arçobispado de Santiago et es arçobispo della e segund vos nos lo prometistes et nos fezestes pleito et omenajen al tiempo que la dicha / (fol. $302 v^{\circ}$ ) fortoleza vos encomendamos et la de vos fiamos, et prometestes de nos la dar et entregar et acojer en ella a nos et a nuestro mandado yrado o pagado o al arçobispo que despues de nos fuese canonicamente proveydo desa dicha igllesia et arçobispado de Santiago conmo agora es el dicho nuestro sobrino; e nos plaze e queremos que la el aya et tenga et le acudades con ella et gela dedes et entregedes. E dando et entregando la dicha fortoleza e casa fuerte al dicho sennor arçobispo, nuestro sobrino, o a quen su poder oviere, e siendo apoderado em la dicha fortoleza e casa fuerte, asy en alto conmo en baixo a toda su voluntade, el o quien su poder para elo oviere, segund dicho es, por la presente a vos alçamos e quitamos qualquier pleito et omenajen que nos fesistes e ayades fecho por la dicha casa e fortoleza para que la podades dar e entregar et la dedes e entregedes e acudades con ella al dicho sennor arçobispo, 
nuestro sobrino, o a quen su poder ovier, et non a otra persona alguna; pleito et omenajen que asy vos teniades fecho de la dicha fortoleza e casa fuerte en fe de lo qual vos mandamos dar esta nuestra carta firmada de nuestro nombre e sellada con nuestro sello del secreto.

Dada en la villa de Bejar, çinquo dias del mes de agosto, anno del nasçemento de Nuestro Sennor Ihesu Christo de mill et quatroçientos e saseenta et quatro annos.

Archiepiscopus Spalensis.

En la çibdad de Santiago, viinte e çinquo dias de agosto, anno del nasçimiento de Nuestro Sennor Ihesu Christo de mill e quatroçientos e saseenta e tres annos, en presença de min, notario, e testigos yuso escriptos, paresçio personalmente Alvaro Sanches de Avila, regidor de la çibdade de Santiago, alcalde de la Rocha Forte, et dixo que el se dava por entrego e apoderado de la dicha fortoleza e casa fuerte, por quanto la tenia en su poder et la tenia basteçida de armas e gente suya de mano del sennor arçobispo de Santiago, don Afonso de Fonseca, que agora es. E prometio, conmo home fijodalgo que tenia la dicha fortoleza et la guardaria para el dicho sennor arçobispo, et que lo acojeria en ella de noche et de dia, ayrado o pagado, con pocos o con muchos, em lo alto et en lo baixo conmo a su senoria plogiese et por bien toviese.

Et otrosy que faria desde la dicha fortoleza gerra o paz por su mandado e conpliria todos los otros sus mandamientos, et que la entregaria et entregara la dicha fortoleza cada et quando que gella / (fol. $\left.301 \mathrm{r}^{\circ}\right)$ demandare el mismo en persona, o la entregaria a quien su merçede embiare mandar por su carta firmada de su nombre et seelada de su sello.

Et otrosy prometio de aver por su rey e sennor natural al rey don Enrrique, nuestro sennor, et de le acojer en la dicha fortoleza de noche o de dia, con pocos o con muchos, ayrado o pagado, e faser desde ella gerra o pas por su mandado segund et en la manera que dicho es. Et que sy teniendo el la dicha fortoleza, acaesçiendo de falesçer desta vida presente el dicho sennor arçobispo, lo que Dios non quera, que el entregaria la dicha fortoleza al arçobispo paltado, eleuto, confirmado, a suplicaçion del dicho sennor rey, fuese canonicamente proveydo por el nuestro muy santo padre de la dicha igllesia et arçobispado.

Çerca de lo qual et cada cosa e parte dello, alen de la promesa suso dicha, fizo pleito et omenajen vna, dos e tres vezes segund fore e custume d'Espana con manos del sennor Fernando de Fonseca, cavallero et home fijodalgo, que del lo reçebio vna, dos e tres vezes segund que dicho es. Et prometio de lo guardar e conplir et mantener en todo segund de suso se contien<e $>$, so pena de traidor e a ter por ello en caso de menosvaler e en todas las otra penas en que caen et encurren los que non entregan las fortolezas aquellas de quien las reçeben e quebrantan su vondade et 
pleito et omenajen, sobrelo qual otorgo vn contrabto forte e firme a vista de letrados.

Testigos el liçençiado Martin Maldonado e Alfonso de Finajeda Algasie.

Et yo Juan de Areualo, escripuano de camara de nuestro sennor el rey et su notario publico en la su corte e en todos los sus regnos e senorios, fuy presente a lo que dicho es en vno con los dichos testigos. Et $<$ del $>$ otorgamiento del dicho Alvaro Sanches de Avila, alcalde, esta carta et publico instrumento fize escripvir e por ende fize aqui este mio signo a cal en testimonio de verdad.

Juan de Areualo.

$[\ldots]^{273}$.

$\left(\right.$ fol. $\left.300 \mathrm{v}^{\circ}\right)$ Las quales dichas cartas del dicho sennor arçobispo, e pleitos e omenajeens, ansy presentados e leydos, el dicho sennor arobispo don Alfonso de Fonseca, arçobispo de Santiago, dixo que requeria a los dichos Alvaro Sanches e Gonzalvo de Figueyroa, e a cada vno dellos, que cunplisen las dichas cartas e pleito e omenajen, segund en ellas se contenia, a cada vno \dellos/ segund lo que le atania e era obligado a cunplyr e gardar por virtude de los dichos pleitos e omenajes e cartas e cartas (sic) del dicho sennor arçobispo de Sevilla. E en cumpliendolas le diesen e entregasen las dichas fortalesas de la Rocha Fuerte de Santiago e castillo de Jallas, fasiendoles por las dichas casas pleito e omenajen a cada vno segund esa que tenia; conviene a saber: el dicho Alvaro Sanches por la dicha fortalesa de la Rocha Fuerte e el dicho Gonzalvo de Figeroa por el dicho castillo de Jallas. Et faser delo ansy que fuere lo que devyan e eran obligados faser, el contrario fasiendo que protestava e pro/ (fol. $299 \mathrm{r}^{\circ}$ ) testo contra los dichos Alvaro Sanches e Gonzalvo de Figeroa e contra cada vno dellos avieren e averen avydo en mal caso segundo el thenor de los dichos pleitos e omenajes.

Et los dichos Alvaro Sanches de Avila e Gonzalvo de Figeyroa, dixieron que obedecian las cartas del dicho sennor arçobispo de Sevilla con la reverençia que devian, e eran e estavan prestes de las guardar e cumplyr e bien ansy los pleitos e omenajes que dicho avian, e de luego dar e entregar las dichas casas, cada vno la suya, al dicho sennor arçobispo de Santiago o a quien su merçed mandase.

Testigos que fueron presentes Diego Alvaro, clerigo, e Pedro de Servante, [...] $\operatorname{dos}^{274}$, e Afonso de Femijedo, alguasil del dicho sennor arçobispo de Santiago. E luego en este mismo momento e ora el dicho Alvaro Sanches fiso pleito pleito (sic) e omenajen en forma devida al dicho sennor arçobispo de Santiago, en

273 Se insertan las escrituras de Gonzalo de Figueroa, en la misma situación que don Álvaro Sánchez de Ávila.

274 Dos o tres letras. 
mamanos (sic) del bachiller Juan Vela, ome fijodalgo, e del lo reçibio por la dicha fortalesa de la Rocha, segund e en la forma e manera del pleito e omenajen que por la dicha fortalesa avia fecho al dicho sennor arçobispo de Sevilla e con sus mismas maneras e condiçiones.

Testigos los sobre dichos Diego Alvaro e Pedro de Servante e Afonso de Femiyeda.

Otro tal pleito e omenajen fizo el dicho Gonzalvo de Figueroa al dicho sennor arçobispo en manos del dicho bachiller Juan Vela por el dicho castillo de Jallas.

Testigos vt supra.

6

1471, noviembre, 7. A Coruña.

Posesión concedida a don Álvaro Sánchez de Ávila, regidor compostelano, en nombre de su hijo, don Gil Rodrígues Varela, de la hacienda de su abuela doña Elvira Fernández, en el lugar de Palavea, feligresía de San Vicente de Elviña (A Coruña).

A.- ACS, S 18/40. 7 fols.

(fol. $1 r^{\circ}$ ) Enna çibdade da Cruña, a septe dias do mes de nouembro, anno do nasçemento de Noso Sennor Ihesu Christo de mill e quatroçentos e setenta e vn anos, este dia e <nna> abdiençia da bespara ante Diego Sanches de Valladolid, alcalde hordinario enna dita çibdade en casas, coutos e terminos por el rey nuestro e por los conçello e foro dela, seendo o dito alcalde judgando os pleitos en sua abdiençia publica segund que ha de vso e de costume e en presençia de min, Gonçalvo Fernandes de Grila, escripvano e notario publico do dito sennor rey en la sua corte e en todos los sus regnos e sennorios e notario publico de numero en la dita çibdad, e dos testigos a juso escriptos paresçeu ende presente Alvaro Sanches, regidor da çibdad de Santiago, por sy e en nome de Gil Rodrigues Barela, seu fillo, e de Maria Gonçalves, sua moller, filla legitima de la horrada donna Elvyra Fernandes, vesina desta dita çibdade, defunta, que Deus aja, moller que fuy de Gil Rodrigues Barela, regidor da dita çibdade de Santiago, que Deus aja, e diso que agora podia aver tres ou quatro dias pouco mays ou menos tempo que a Elvyra Fernandes, aboa legitima do dito Gil Rodrigues, seu fillo, e da dita Maria Gonçalves, filla da dita Elvyra Fernandes, falesçeu desta presente vida, segund que era notorio, da qual era herdeiro dereito vniversal o dito Gil Rodrigues, seu neto menor; ela por seu testamento avia feito e estabeleçido por seu herdeiro legitimo vniversal a o dito Gil Rodrigues Barela, seu neto, según por seu 
testamento paresçeu, o qual avia pasado por ante Gomes Fernandes de Santiago, notario do numero desta dita çibdade, lo qual logo ante o dito alcalde, e por min, o dito notario, presentou e leer e abrir fiso e levou en seu poder para sua garda. Por onde diso que por e en nome do dito Gil Fernandes Barela, seu fillo, cujo tutor legitimo era segundo dereito, neto legitimo, herdeiro, da dita Elyra Fernandes, que el açebtaba e açebtou en nome do dito seu fillo los bees e hereçia da dita Elvyra Fernandes, sua aboa, con protestaçion de non ser a mays obligado de quanto abondase la herençia da dita Elvyra Fernandes, aboa do dito seu fillo / (fol. $\left.1 v^{o}\right)$, sacada sua legitima de seus bens e herençia que por dereito lle vyna.

E diso que por e en nome do dito seu fillo e neto da dita Elvira Fernandes, cujo tutor legitimo era, pedia, frontava e requeria a o dito alcalde que de seu ofiçio judiçial, lo qual diso que ynplorava e ynplorou, reçibiese e aprovase la dita sua açebtaçion dos bens e herençia da dita Elvira Fernandes, e reservase çerto de lo seu dereito a salvo a o dito Gil Rodrigues, menor, e a el en seu nome; e diso que o dito sennor alcalde, non lo fasendo nen querendo asy faser, diso que protestava e protestou o dereito do dito Gil Rodrigues, seu fillo menor, e seu en seu nome, senpre ser e quedar a salvo, e se non $\mathrm{p}[\ldots]^{275}$ dar por pasamento de tenpo en $\operatorname{pal}[\ldots] \mathrm{o}^{276}$.

E logo, o dito sennor Diego Sanches, alcalde, diso que visto en conmo notoriamente o dito Alvaro Sanches era padre do dito Gil Rodrigues, neto da dita Elvira Fernandes, en seu pedimento, ser justo que el a[...]to ${ }^{277}$ podia e con dereito devia que reçebia e reçebeu a dita açebtaçion e protestaçion ante el feita por lo dito Alvaro Sanches en nome do dito Gil Rodrigues Barela, seu fillo menor, e neto da dita Elvira Fernandes, e que açerca delo lle reservava e reservou seu dereito a salvo para que lle non pasase por pasamento de tenpo e de todo en conmo pasou o dito Alvaro Sanches en nome do seu fillo, e para el diso que lo pedia e pedeu asy por testimonio a os presentes, rogava que le fosen delo testigos.

Et despoys desto estia dia, ora, mes e ano suso ditos, seendo o dito sennor Diego Sanches, alcalde en la dita sua abdiençia publica das besparas, judgando os pleitos segund que ha de vso e de costume, enna presençia de min, o dito notario, e dos testigos a juso escriptos, logo o dito Alvaro Sanches por e en nome do seu fillo menor, diso que por quanto segund coonstava (sic) e paresçia por lo dito testamento ante el presentado en la dita abdiençia e segund que era publico e

\footnotetext{
275 Una o dos letras.

276 Cuatro o cinco letras.

277 Cuatro o cinco letras.
} 
notorio a dita Elvira Fernandes, aboa do dito seu fillo menor, avia mandado de seus bens en eso meesmo, antes( $(\dot{i})$ de sua morte, dado en que ca[... $]^{278}$ moy moyto mays a alende / (fol. $2 \mathrm{r}^{\circ}$ ) de seus bens de la quinta parte en dereito estabeleçida, e a non mays de la metade, e diso que por qanto segundo dereito el testador e toda persona que aya fillos ou netos que avia dereito de herdar non podia dar nen mandar de seus bens mays da quinta parte para descargo da sua alma, e todolos legatarios devian de aver los lugares por mano do tal herdeiro de tal persona testante. Por ende diso que por e en nome do dito seu fillo e neto da dita Elvira Fernandes que podia e requeria en lo mellor modo que con dereito podian e devian a o dito sennor alcalde que non apoderase nen mandase meter e apoderar a legatarios algunos, contenidos en la dita manda e testamento de la dita Elvira Fernandes e en seus codeçilos e en oitras suas vltimas voontades, seu o dito seu (sic) fillo menor e el en seu nome primeramente $\mathrm{s}[\ldots]^{279}[\ldots] \operatorname{amados}^{280}$, oydos e $\operatorname{vnçidos}(i)$ por fio e por dereito por donde deve e conmo deve sobrelo, e que eso mesmo lo posese e apoderase en nome do dito seu fillo menor en la posesion çevill e natural e corporal e real e abtual de todos los bees mobles e rayses, moventes e semoventes, e herençia da dita Elvira Fernandes, que seus eran e lle pertençian antes e a o tenpo de seu falesçemento. E el asy posto e apoderado en eles, lo defendese e mandase defender con eles en la dita posesion e mandase e defendese da parte do dereito e del rey, nuestro sennor, e da sua conmo sua justiçia, que persona alguna non faser ou sacar de apoderar a os taes ligatarios en los taes legaros nin los entrar nen tomar, nen entrar nen tomar (sic) nen comprar los ditos bees e herençia da dita Elvira Fernandes a o dito menor e a el en seu nome pertenesçientes nen parte deles, so as penas en tal caso estabeleçidas en deperdad (sic) de qualquer dereito que a elo ou parte delo ouver ou pretendesen aver. E diso que o dito sennor alcalde fasendolo asy fara ben e aquello que destoutra obligado en outra maneira non lo querendo asy faser e fasendo lo contrario diso que protestava e protestou o dereito do dito seu fillo e seu en seu nome, sempre ser e quedar a salvo e de se non perder por pasamento de tempo en que todo quanto dos ditos bens e herençia da dita Elvira / (fol. $2 \mathrm{v}^{\circ}$ ) Fernandes fose entrado e tomado e apoderado que fose todo ensyui[... $\mathrm{o}^{281}$ e deui[... $\mathrm{o}^{282}$ valor conmo cousa feita en perjudiçio do dito menor e sen o dito menor e el en su nome ser

278 Dos o tres letras.

279 Tres o cuatro letras.

280 Dos o tres letras.

281 Dos o tres letras.

282 Dos o tres letras. 
chamado, oydo e vnçido (sic) por donde e conmo devian e pideu testimonio. Et logo o dito alcalde diso que visto o pedimento do dito Alvaro Sanches, por sy e en nome do dito seu fillo, ser justo e consolante a la rason que el en quanto con dereito podia e devia en quanto a dita Elvira Fernandes en su testamento e codeçilos e doaçons exçedera la forma do dereito que contrareo reservaba e reservou a o dito menor e a o dito Alvaro Sanches, su padre, e en seu nome seu dereito sempre a salvo para que se non perdese ne podese perder por pasamento de tempo. E diso que desde ali poyna e apoderava e mandava e mandou poner e apoderar a o dito Gil Rodrigues, menor, neto da dita Elvira Fernandes e a o dito Alvaro Sanches, seu padre, en seu nome, en la tenençia e posision çevill e natural e corporal, real e atual de todos los bees moveles e rayses, casas e casares e vinnas e herdades, lavradas e montesas, e herençia que foran e ficaran da dita Elvira Fernandes e lle pertesçian en esta dita çibdade da Crunna e en seu cauto e jurdiçon e $a b[\ldots] \operatorname{tas}^{283}$ deles en todos los outros bees que lle pertesçian ni outros quaes quer partes e lugares que lle pertensçesen e pertesçer devesen, asy de feito conmo de dereito, çerqua do qual diso que mandava e mandou dar seu mandamento de apoderamento en forma devida e acostumada, e diso que mandava e mandou e defendia e defendeu de parte do dereito do dito sennor rey e de seus justiçias que persona alguna non fose ousado de entrar los ditos logares e doaços en tomar nen entrar nen comprar a o dito Gil Rodrigues, menor, nen a dito Alvaro Sanches en seu nome, los ditos bees e herençia da dita Elvira Fernandes nen alguna parte deles syn primeiramente o dito Gil Fernandes, menor, e o dito Alvaro Sanches, seu padre, en seu nome sobrelo seren chamados, oydos e vnçidos por feito e por dereito, por donde devian e conmo devian, so pena que aquel ou aqueles que o contrario fesesen que apor / (fol. $3 \mathrm{r}^{\circ}$ ) eso mismo feito perdesen e ouvesen perdido qual quer dereito que a elo e a qual quer cousa e àrte delo ouvesen pu pretendesen aver e das otras penas en tal caso en dereito estabeleçidas; e que asy lo mandava e mandou en estes presentes escripto e por eles.

E de todo en conmo pasava o dito Alvaro Sanches por sy e en nome do dito seu fillo menor, diso que pedia e pedeu a min, o dito notario, que llo dese asy todo por testimonio sygnado para guarda e conservaçion do dito seu fillo menor e seu en seu nome e que rogava a os presentes que lle fosen delo testigos. E foron a elo todo presentes por testigos Gomes Patinno, bachiller, e Ferrand Alvaro da Freija, e Françisco Yanes, partes, e Juan Lopes de Vilamido e Sancho Rodrigues e Juan Martines Barela, mercadores, vesinos da dita çibdade, e otros.

283 Dos letras. 


\section{7}

1471, diciembre, 11. Santiago de Compostela.

El arcediano de Trastámara declara ser tenenciero de la tenencia de Reis pero que la posee en fieldade por Álvaro Sánchez de Ávila, y que, falleciendo don Álvaro, dicha tenencia volvería al Cabido.

A.- ACS, IG 475, fol. CXVIr ${ }^{\circ}$.

\section{En conmo el arçidiano de Trastamara diso e declarou que tinna a tença de Reys salvo en fieldade.}

A XI dias do mes de dezembro de LXXI, seendo os sennores en seu cabildo enna torre nova por tangemento de campaa, segundo que han de vso e de costume, abeu, a saber: Martin Lopes, cardeal e vicario, e el arçidiano de Trastamara e Diego Alonso, Andres Rodrigues e Pero Fernandes, Pero de Mourelos, cardenales, \Alonso Yanes, cardeal/, e don Diego de Castilla, mestrescola, e Rodrigo de Leyra e Juan de Adans(i), jueses de Vellestro e de Luou, e Pero de Souto e Vasco Martines, bachiller, e Loys de Paramo, Martin Fagundes, Roy Gomes, Gonçalvo de Valdiveso, Martin Abad, Andres Fernandes e Martin Ximenes, canonigos desta santa iglesia, e en presença de min, notario e testigos, o dito sennor arçidiano de Trastamara diso que non ostante que el era tençeiro da tença de Reys, que era do dito Cabildo, que a non tinna salvo en fieldade por Alvaro Sanches d'Avila, regidor desta çidad, durante sua vida, e que desde aqui outorgava e conosçia que acontesçendo o falesçer do dito Alvaro Sanches da presente vida que a dita teença quedase libre e vaca a o dito Cabildo para que sen seu enbargo podese o dito Cabildo fazer dela sua libre voontade asi conmo de sua cousa propria; e de conmo pasou Juan Garcia, canonigo e procurador dos ditos sennores, asi o demandou por testemoyo synado.

Testigos os sobreditos Pero Fernandes, cardeal, e Martin Fagundes e Loys de Paramo. (Rúbrica).

\section{8}

1472, agosto, 31. Lunes. Santiago de Compostela.

Se concede autorización a los procuradores para poder recibir las fianzas de la tenencia de Reis pagadas por la esposa de Álvaro Sánchez de Ávila, Inés García.

A.- ACS, IG 475, fol. CXXVr'

Poder a os procuradores para reçeber las fianças de Ynes Garçia, moller de Alvaro Sanches d'Avila, sobre la tenençia de Reys. 
Luuns, postrimeiro dia do mes de agosto de LXXII, seendo los sennores benefiçiados en seu cabildo, segundo han de vso e costume, mandaron <a> Andres de Trabasos e a Pero da Crunna como procuradores tomasen e reçebesen de Ynes Garçia, moller de Alvaro Sanches, regidor da çibdat de Santiago, fiadores para segurança dos fructos e rentas pertenesçentes a a tenençia de Reys deste anno de LXXII, e esto por quanto as alterquaçion $<\mathrm{s}>\left({ }_{i}\right)$ lentre/ o Cabildo e o dito Alvaro Sanches sobre la tenençia, disendo non teer justiçia nin dereyto a as rentas e fructos da dita tenençia segundo mays la[...]ramente ${ }^{284}$ pasou por Alvaro de Castenda, notario.

Testigos Roy Peres, Juan Garçia, Juan de Barrentos, Martin Fagundes, canonigos, e outros.

Pasou por Alvaro de Castenda.

\section{9}

1472, noviembre, 26. Santiago de Compostela ${ }^{285}$.

Concesión del Cabido compostelano a Álvaro Sánchez de Ávila de la tenencia de Reis, con una serie de condiciones.
A.- ACS, IG 475, fol. CXXIXr ${ }^{\circ}-v^{\circ}$.

\section{(fol. $\mathrm{CXXIXr}{ }^{\circ}$ ) Contrato do alcalde da Rocha sobre la tenençia de Reys.}

Predito $^{286}$, os ditos sennores vicario e Cabildo diseron que por quanto por parte de noso sennor el arçobispo fora rogado se ouvese vertuosamente con Alvaro Sanches de Avila, regedor de Santiago, sobre rason da teença de Reys, que he de dito Cabildo, e por outros rexpectos (sic), e que eles de seu proprio moto, nemine (sic) discrepante, quiseron e outorgaron que o dito Alvaro Sanches ouvese e levase en todo tenpo de sua bida a dita tenençia de Reys, fructos e rentas a ela pertesçentes e por la renda, maneira e condiçoos que a de antes tinna, e con estas condiçoos e non sen elas: la primeira que a ponna en benefiçiado que a por el en seu nome tenna e de fianças de pagar la renda e preçio que por ela dava a o dito Cabildo; la segunda que repare las casas que son da dita tenençia doje a huun anno cumplido a vista de dous benefiiados e de ofiçiaas; la terceyra que onrre a todos los benefiçiados en general e cada huun en particular; la quarta que fallesçiendo o dito Alvaro Sanches que la dita tenençia quede libre e desembargada con suas rentas e perfectos a o dito

\footnotetext{
284 Dos o tres letras.

285 Datado por el auto capitular: a XVI dias do mes de novembro do anno de LXXII.

286 Entendemos que se refiere a día, mes y año susodichos.
} 
Cabildo, e fallesçendo o tal benefiçiado en que ansy poser la dita tenençia que posa nomear outro benefiçiado que por el e en seu nome tenna la dita tenençia durante o tenpo da sua vida do dito Alvaro Sanches, a qual prometeron no lla quitar e caer.

E o dito Alvaro Sanches asy la reçebeu e outorgou, e para o asnsy cumplir e guardar nomeou <a> Alvaro Garçia, canonigo, por tenençiero da dita tenençia, e o dito Alvaro reçebeu la dita tenençia e dou por / (fol. CXXIXv ${ }^{\circ}$ ) fiadores a Castro Rodrigues Varela e Roy Gomes, canonigos, que outorgaron la dita fiança segundo forma das costituiçoos, e o dito alcalde, para guardar e cumplir o suso dito, dou sua re[...] $\mathrm{s}^{287}$ de don Diego de Castilla, mestrescola, que presente era, que a del reçebera, de guardar onrra do dito Cabildo e benefiçiados de, ansy en general conmo en particular.

Outorgaron carta firme so pena de doblo.

Testigos vt supra.

\section{0}

1478, [enero], 12. Santiago de Compostela.

Auto capitular que recoge el juramento de ayuda al Cabildo compostelano por parte de Álvaro Sánchez de Ávila, regidor y alcalde de la ciudad de Santiago, junto con otros regidores y alcaldes de la misma.

A.- ACS, IG 475, fol . CCXXVIv'.

\section{Juramento dos allcaldes da çidade de Santiago.}

A XII de LXXVIII, seendo os sennores en seu Cabildo, enna torre nova, segundo que ha de vso e de costume, conben a saber, Gomes Fernandes, cardenal e vicario, e Meen Gomes e Andres Rodrigues, cardeaas, e don Diego de Castilla, mestrescola, e Gonçalvo de Vlloa, e Francisco Alonso, Martin Vse, Alonso Gonçales, Juan de Gadeja, Honçalvo Lopes, Gonçalvo Rodrigues e Andres de Travasos e Juan Gonçalves, enno dito Cabildo Alvaro Sanches de Abila e Juan Martines(?) Vinagre, regidores e alcaldes da çidade de Santiago, fezeron juramento en forma de gardalos henrros e libertades dos ditos sennores do Cabildo e iglesia de Santiago e de seus criados e familiares e $[\ldots]^{288}$.

Testemoyas Juan Gonçalves e Gonçalvo Rodrigues e Andres de Travasos.

Pero Suares, notario apostolico (rúbrica).

287 Tres o cuatro letras.

288 Palabra de tres o cuatro letras. 
1485, octubre, 25. Santiago de Compostela.

Nombraamiento de Juan Guedeja, canónigo compostelano, como tenenciero de la tenencia de Reis por Álvaro Sánchez de Ávila, que la tenía por delegación del Cabildo, recogido en acta capitular.

A.- ACS, IG 476, fol. $69 v^{\circ}$.

Alcalde da Rocha.

A XXV dias do mes de octubre de LXXXV annos, sendo os senores benefiçiados da santa igllisia de Santiago asentados en seus cabildo $<$ s $>$ dentro enna Torre Nova, segund que han de vsu e custume: Andres Fernández, cardenal e vicario ennos auctos capitulares $\mathrm{m}[\ldots]^{289}$, Pero Fernández, cardenales, Juan Garcia de Gomara, thesoureiro, Pero de Souto, Pero Muniz, Gonçaluo Rodrigues(i), Gonçaluo de Jahem, Travazos, Juan de Santiago, Juan de Monte Mayor, Juan Guedeja, Juan de Medina, Juan Calvinno, Alonso Peres, Pero de Muro e outros, que quiseron e poderon ser presentes, por ante min, o dito notario infra scripto, Alvaro Sanches de Avila, regidor da çibdad de Santiago, nomeou por tençeiro da tença de Reys, que ten do dito cabildo, e segund e a o thenor de hun contrabto, a Juan Guedeja, canonigo, segund e por las condiçions que a tinna do dito cabildo, obligando asy, e seus bens, de pagar e tener o contrabto e de reparar as casas da Rua Nova que son da dita tenençia a vista de visitadores dados polo dito Cabildo. E o dito Juan Guedeja, canonigo, diso que se aviu e outorgou por tençeiro da dita tenençia en nome do dito Alvaro Sanches.

Os ditos sennores reçeberon por tençeiro a o dito Juan Guedeja da dita tenencia de Reys, segund e a o thenor do dito contrabto e non yndo nen pasando contra el.

Testigos vt supra.

(Rúbrica).

12

[1489], sm., sd. [Santiago de Compostela].

Testamento de don Álvaro Sánchez de Ávila, regidor compostelano y tenente de la fortaleza de A Rocha Forte.

B.- ACS, LD 5/1. 3 fols.

289 Palabra de cuatro o cinco letras. 
(fol. $1 \mathrm{r}^{\mathrm{o}}$ ) In nomine Domini, amen.

Sepan quantos este instrumento vieren como yo, Alvaro Sanches de Avila, regidor de la çibdad de Santiago, jaziendo doliente en cama de infirmidad corporal, e con todo mi juizio natural, tal que Dios me lo quiso dar, et temendome de la muerte, por que tengo de pasar, faço mi manda vltima e postrimera voluntad.

Primeramente mando mi anima a mi Señor Ihesu Christo que la compro e redemio por su preçioso e justo sangre, et luego a mi Señora la Virgen Maria, su madre, que sea mi avogada a la ora de la muerte e al dia del grand juizio, e ruegue a su Fijo bendicho por min, pecador, que aya misericordia de min e non quera mirar a mis maldades e pecados, que son muchos. Et ruego a los byenabenturados apostollos San Pedro e Santiago, con todos los otros apostollos, e a Sant Lorenço e a Sant Sebastian e a Santo Estevan, con todos lols/ martires, et a la señora Santa Catalina e a Santa Vrsula, con todas las virgines, et al señor Sant Françisco e a Santo Domingo, con todos los confesores, et al señor Sant Migueel, Sant Grabiel, con todos los ángeles, queran rezar por min e nuestro señor Ihesu Christo quiera llevar mi anima a su Santa Gloria e me de graçia e acabe en verdadera penitençia.

Yten mando mi enterrar en el monesterio de San Payo d'Antaltares desta dicha çibdad de Santiago, en la capilla que yo fago, que ha de ser de vocaçion de Santa Maria de San, mi volcaçion (sic), que esta a la mano esquierda de conmo ombre va al altar mayor. Et mando que el dia de mi enterramiento me fagan las exsequias e horras e digan las misas segund a mi estado pertenesçe. Et mando que ata los septe dias que cada dia digan dos misas con sus responsos e los septe dyas los segund costumbre, e asy $\mathrm{m}[\mathrm{i}] \mathrm{smo}$ pertenesçe a mi estado e mis complidores vieren que mejor se puede faser, e asy a los quoreenta dias et al cabo del ano me digan cada dya vna misa en la dicha capilla o en el altar mayor de dicho monesterio, non sendo acabada la dicha capilla, e vayan sobre mi sepultura con responso e agoa bieita.

Iten mando que den de vestir a doze pobres sayas e lobas.

Iten mando que se procure e travaje que para la dicha capilla que asy mando faser en el dicho monesterio de Sant Payo, para los clerigos que an de traer cargo della, conmo se annexen la meytad sencura de Sant Minno de Ares, et la quarta parte sencura del benefiçio de Santo Adraao de Corme, con mas la hermita de Santa Maria de Giestenla, que sea junto con el dicho beneficio de Corme, et mas la hermita que esta junto con la ygllisia de Ares de que yo soy padron e lo seera mi herdero despues de mi fallescimiento, de la renta de lo qual todo ansy anexo, ayan de estar perpetuamente dos capillans atitulados regiendo la dicha capellania que ayan la renta de lo ya dicho por eguales partes; los quales ayan de ser elegidos e apresentados quanto vacare, e agora quando se estabelesçiere por mi herdero, et despues del por los cardenales mayores que fueren e por el que agora es de la santa ygllisia 
de Santiago et por el abat que es o fuere del dicho monesterio. Et se estos non se acordaren e fueren discordes en la apresentaçion que se requiera mi herdero sufiçientemente e donde los dos elegieren e presentaren que aquel sea capillan perpetuo de la dicha capilla, insutuido (sic) por quien insutuirlo pueda / (fol. $\left.1 \mathrm{v}^{\circ}\right)$ en ella, los quales dichos capillanes quiero et es mi voluntad que sean, al tiempo que fueren elegidos, apresentados a la dicha capilla clerigos de misa [...]ibentes ${ }^{290} \mathrm{e}$ comorantes en esta çibdad, et que sean obligados de dizer cada vna misa se se podiere aver aviles en ella antes que en otras partes, serviendo la dicha capilla mals/ cada vno su semana de manera que sean trezientas e sesenta e seys misas, rezadas de cada vn anno, et se la renta de los dichos benefiçios e hermitas non rentasen fasta doze mill maravedis que se asiente de otro mi patrimonio fasta en complimento dellos por mi herdero e complidores, que abaxo se ajan contenidos; et ruego e pydo por merçed al reverendisimo sennor arçobispo de Santiago, mi senor, o a quien su poder oviere, que a todo lo que dichos es, para que sea todo ello perpetuo e duradero para sempre jamas, interpongan su abtoridad e decreto en que se faga e cumpla lo que por mi ver[... $]^{291}$ desto des[... $]^{292}$ fue e es e esta declarado; e los tales capillanes sean sempre obligados de rogar a Nuestro Señor por las animas de aquellos cuyo siempre fue lo ya mandado e dispuesto de min e de mi fijo Gil Rodrigues Barela, espeçialmente.

Yten mando que se algund ombre o muger veniere quexando que le soy en cargo, que sea ombre o muger de honrra e de conçiençia e conosçido por tal, sean treydos por su juramento e les satisfagan; et se fueren ombres de otra suerte que les satisfagan lo que mostraren por obligaçion o de otra manera que paresca çierto e justo.

Ytem mando a mi muger que le den e entrege $<\mathrm{n}>$ e desenbargen toda su fasienda raiz e foros a $[\ldots]^{293}$ que yo alguna razon touiese a ellos por me los aver ella dado en casamiento quando comigo caso et todo lo muevle que ella declarare por su juramento que consiguio por mi trauaxo quando conmigo caso; et queriendo vebir en esta mi casa en que yo e ella al presente bebimos que lo pueda faser en toda su vida, contanto que al tiempo de su muerte quede libre de mi herdero. Et se esto non quisyere e demandare la meytad del prefecto de la dicha casa, como quera que entre mi e ella esta un contrato que paso por ante Alvaro de Casteenda, notario, que nos avemos de demandar prefecto vno al otro de los perfectos que fezieremos, asy en su

\footnotetext{
290 Dos o tres letras.

291 Dos o tres letras.

292 Tres o cuatro letras.

293 Tres o cuatro letras.
} 
fasienda conmo en la mia, que esten con ella a justiçia e le satisfagan aquello si fuere jusgado. Et la casa quede libre a mi herdero syn que ella en ella biba algund tiempo. Et en satisfaçion de algund travajo, se conmigo lo llevo, le mando la meytad de la renta do Ejo en toda su vida et despues quede libre a mi herdero.

Yten mando a Alvaro de Camanno, mi criado, seys mill partes de brancas. Iten mando a mi criada María de Finojedo veynte mill maravedis partes para ayuda de su casamento e non dotra manera e mando que para su boda la vystan byen e le den cama de ropa e dos calderas e picheles e las otras cosas segun costumbre. Yten le mando mas la mi casa en que agora vybe e mora Pedro da Pusa, correeyro, que es en la Rua de la Algara de Çima. Item mando que dexem morar a Rui de Camba en toda su vida en aquella casa en que agora vibe que es en la Rua de Villar, que yo tengo de foro de Santa María de Coonjo e de los capillanes de las capillas desta çibdad e / (fol. $2 \mathrm{r}^{\circ}$ ) al tiempo de su fallesçimiento e desde agora nombro por voz a la dicha Ynes Garcia, mi mujer, contrato que dexe bebir al dicho Ruy de Camba en toda su vida en la dicha casa.

Yten nombro por voz en el foro que yo tengo de los sennores e Cabildo de la santa yglesia de Santiago, que son el coto de Miinno de Calvos e de so caminno et el coto de Minoos, e lo del coto d'Oyns con los casares de Parente e Sebeo, segund se contine en el contracto de aforamento a mi fija Catalina Sanches, al tenor e forma del.

Yten mando que la cortina que esta cabo la puerta del Algara de Baxo de fuera de la çibdad qua agora tiene Costança de Vilazide, muger que fue de Alvaro Domingues, carniçero, que la tenga en su vida, e al tiempo de su fallesçemento quede libre al ospital de Santiago. Item porque yo soy a cargo al ospital de la rua del Caminno que hedefico Ruy Sanches de Moscoso, arçediano de Deça, de que los regidores desta çibdad son padrons, mando que le den, para reparo del dicho ospital, tres mill maravedis de partes de blancas. Item por que soy a cargo a vn viudo mendigante estrangero, que no se donde hera, e jaze enterrado en Santa Maria a Noba, mando que le digan coreenta misas, rezadas $<$ por $>$ los frayres del dicho monesterio e les den mill partes de brancas.

Iten mando que se algund herdero de Loys Domingues Tasarro, ja defunto, que bebya en terra de Campos, allende Astorga, veniere e demandare en nombre del dicho Loys Domingues e fuere su verdadero herdero o con su poder del dicho herdero, mando que le den quatro mill partes de blancas, menos una dobla, que le soy a cargo.

Yten mando al candelero que dizen de Santeylafon(i) en que ponen las candelas, que esta antel cruçifixo entre el coro e el altar de la santa ygllisia de Santiago, la renta e la casa en que agora mora Juan da Ameixeira, xastre, ques en el Algara 
de Çima, la qual el dicho Juan da Ameixeira tiene aforada de manera que durante el fuero della el dicho candalero aya aquella, e fenesçido el dicho fuero aya la dicha casa e la renta della el dicho candelero con esta condiçion: que alumbre depues del termino que solen alumbrar lo que a abastare lo que asy rentare la dicha casa. Et esto que lo tenga en cargo de faserlo e complirlo el dean de Santiago o su vicario, en cargo de conçiencia. Et esto, se por ventura el procurador que pone la decha confraria para alumbrar non lo feziere conmo deve, que el dicho dean o su vicario lo apremen que lo faga.

Iten mando que mis complidores asenten dos aniversarios en mi fazienda en la yglisia de Santiago; et el vno se diga en dia de los Innoçentes de las ochavas de Navidad, e el otro que se diga a quinse dias del mes de junio, e que mis complidores, con el herdero, den de mi fasenda propya lo que rasonablemente baste para esto, de manera que se aga para im perpetuum.

Item mando a los monesterios de Sant Françisco e de San Lorenço de a çerca, desta çibdad de Santiago, a cada vno un pano pudillo para habitos, para en satisfaçion de algunos abitos que le soy cargo, e lo mas por serviçio de Dios. E mando a todos los otros monesterios de la dicha çibdad, e junto con ella, asy de onbre conmo de mugeres, a cada vno çinco libras de azeyte para la lunbre dellos.

Yten mando a cada vna de las dos malatarias de Sant Lasaro e Santa Marta de arredor desta çibdad seysçientas partes de blancas a cada vna / (fol. $\left.2 \mathrm{v}^{\circ}\right)$ para çapatos e camisas e para los lazarados que en ellas estovieren.

Item mando a vn fijo de Ruy de Santa Aya que se llama ***294, porque le soy algo cargo, e por descargar el anima de mi fijo e de su madre, que santa gloria aya, el mi casal que tengo en Corto, que es en terra de Seaya.

Item mando que qualquiera cosa que mis complidores e heredero quisieren faser en penar o bender de mi fasienda para complimento de la dicha mi manda, lo pueda faser contanto que se aga de la forma desta manda e testamento.

Yten mando que porque quedaron algunas cosas de complir de la manda que fiso Elvira Fernandes, mi suegra, que santa gloria aya, de pyas cabsas, dygo que se cumplan, porque ella mando otras cosas que exçedian la quinta parte e tenia heredero e por derecho no valia nada.

Item mando a Fernando de Presedo, mi criado, fijo de Juan Presedo, que Dios aya, mi cavallo e mi falda e boçetes e diez mill maravedis para ataviarse.

Yten mando a las ordenes de redençion de los Captivos e de la Merçed e de Santa Eulalia de Barçalona a cada vno çent parte de blancas.

294 Espacio en blanco. 
Item mando que se den a Juan Zubyo e a su mugier, que han criado mi nieta Belica, çinco mill maravedis pares de blancas, e que les den sus lutos como los otros mis criados.

Item mando a Rodrigo Arias e a Françisco Clerigo, mis criados, a cada vno mill partes de brancas e sus lutos.

Item mando a Gomes de Ponte, mi criado e colaço, que le den su luto et mas le nonbro en el foro del monesterio de Bregondo que tengo de çertos casares que son sytos en la felegresia de Pereyra, que es en Montanos, los quales se llaman los casares de Çerdido.

Yten mando a Catalina de Pontevedra e a su marido que les den sus lutos e dos mill maravedis partes de blancas.

Iten mando a Arias, mi criado, su luto e quatroçientos maravedis de partes.

Iten mando a los fijos de Ortiz que estan en mi casa, a cada vno, su luto e mill partes de blancas.

Iten mando a la fija de Presedo, que esta en mi casa, su luto e tres mill partes de brancas, que le den quando se desposare por palabras de presente con el que oviere de ser su marido.

Iten mando a Maria, mi criada de seruiçio de casa, su luto e quinentos maravedis de partes e mas se alguna cosa le deuen de sus soldadas que ge lo paguen.

Item mando a Ynaçio e a Diego e al Françes e a Rodrigo, mis criados, sus lutos e cada trezientos maravedis de partes, e c[...] $\mathrm{o}^{295}$ Rodrigo que le non mando mas de dosientos $(\dot{i})$.

Item mando que den al clerigo de Reys su luto.

Item que se otras personas vieren mis complidores que se deven de dar lutos que sean o ayan seydos mis criados e criados (sic), mando que ge los den de manera que con los ya dichos de suso sea veynte e quatro lutos e non mas. Item quiero, e es mi voluntad, que de Beliça, mi nieta, fija de Catalina Sanches, mi fija, e de Juan de Presedo, su marido que fue, y defunto, tenga la tutela e guarda ansy della conmo de sus byenes Françisco Trebino, regidor desta çibdad de Santiago, al qual conmo a mi buen e espeçial / (fol. $3 \mathrm{r}^{\circ}$ ) amigo ge la encargo, non mas ni menos que sy fuese fija propia, mia o suya.

Yten dexo e encargo a los dichos mis complidores e heredero, que abaxo seeran contenidos, que bean las mandas de Vaasco Peres de Vaamonde e de Juan Francisco de Salnes, escuderos, e de Pero Manso, armero, vesino que fue desta çibdad, ya defunto, de los fijos e fijas de los quales yo quede e fique por tutor e guardador de

295 Tres o cuatro letras. 
sus byenes, que miren para ellos e lo ayan e tengan a cargo conmo segund que yo hera e soy obligado, conmo quiera que dygo que los fijos de Pero Manso non les soy en otro cargo salvo de lo que mi muger sabe, conçiençia tiene ella, dira lo que es de[...]bo ${ }^{296}$. Et mando que den mas a Juan Manso, azibichero, fijo del dicho Pero Manso, tres mill partes de brancas.

Iten fago e establesco para mi vniversal heredero en todos mis byenes muebeles e rayzes e semoventes (sic) mis mandas e legados complidas al honrrado sennor bachiller Pedro d'Almança, justiçia e alcalde mayor de la çibdad e arçobispado de Santiago, por el reverendysimo sennor don Alfonso de Fonseca, arçobispo de dicho arçobispado, mi sennor, al qual conmo bueno e verdadero amigo, le encargo su conçiençia para que mire por mi anima, asy conmo el queria que se mirase e aya de mirar por la suya el que despues quedase o quedare.

Et por compridores desta mi manda e testamento fago al dicho mi heredero et a los honrrados Rui Peres e Juan Guedeja, canonigos de la santa ygllisia de Santiago et al dicho Françisco Trebinno, regidor e vesino de la dicha çibdad de Santiago, a los quales <a>çerca de lo que se ha de complir, que es contenido e se contiene en esta mi manda e tratamento, encargo e ruego que açebten, tomen e resçeban en sy el cargo que asy les do de complidores. Et açebtando aquel conmo buenos e fieles amigos, en que yo tengo tanta esperança conmo en mi mismo que lo faran e compliran conmo tales, cumplan lo contenido e por mi mandado e legado, de manera que en todo ello descarguen mi conçiençia, bien asy conmo ellos queiran que lo fagan e ayan de faser aquellos que ellos al tempo de sus fallesçementos dexaren por complidores de sus mandas e testamentos.

Et esta doy e otorgo por mi manda e de testamento e por mi vltima e postrimera voluntad. Et doy por ningunas todas las otras mandas e codiçillos que tengo fechas, et quiero es mi voluntad deliuerada que avnque otras mandas e testamentos mios parescan que ayan e tengan e que en ellos esten qualesquier clausolas derogatorias para derogar aquellos se auia asy de faser, o segund derecho se requiera que se faga mençion en esta mi manda e testamento que no balgan ni ayan ni tengan fuerça, vigor ni efecto alguno, por quanto mi voluntad, conmo ya dicho es de suso, que esta e non otra aya de ser mi manda testamento vltima postrimera voluntad, e por tal la do e otorgo. Et aparto todos los otros mis parientes e parientas e qualesquier otras personas en çinco solidos, e que a mas de mys bienes non se estendan ni aquellos ni otras ningunas personas vayanse contra esta mi manda / (fol. $\left.3 v^{\circ}\right)$ e de lo contenido en ella, en juizio o fuerza de juizio fuerem o pasarem. E en

296 Dos letras. 
la misma penna cayan las personas de suso nombradas a quen yo mando lo contenido en esta mi manda de suso narrada se contra o contra qualquier cosa o parte della fueren o pasaren et para quanto arriba es contenido, que se den veynte e quatro lutos mando que den tantos quantos byen vysto fuere a mi herdero e complidores.

Iten mando que den a los herederos e complidores de Gonçalo de Cumero, çapatero, lo que mi heredero e complidores vieren que es byen por una taça que le pennore de çertas penas en que cayo sendo alcalde ordinario de la çibdad.

Iten devo a Costança dos mill e trezientos maravedis partes por rason de las alcavalas del Girio del anno pasado de ocheenta e ocho, mando que ge los paguen. Iten mando a la confraria de los clerigos de coro el mi casal de Pinnero que agora por min labra $* * * 297$, labrador, et que les mando con tal condiçion que me digan e fagan perpetuamente los clerigos de la dicha confraria los aniversarios que los dichos mi heredero e complidores byen visto fuere e con ellos asentaren de manera que sea perpetuamente.

Iten mando mas a la dicha Catalina Sanches, mi fija, la terra de Vendanna, et pido e suplico al dicho reverendisimo sennor arçobispo de Santiago, mi sennor, que, conosçiendo mi voluntad, e avyendo acatamento a ella e a los serviçios que he fecho a la santa ygllisia de Santiago e a su reuerendisyma sennoria, aya e tenga por byem de dexar dicha terra a la dicha Catalina Sanches, mi fija, a lo menos durante el tiempo de su vida.

Al dorso: Traslado del testamento del alcayde de la Rocha, que Dios aya.

\section{3}

1493, junio, 12. Santiago de Compostela.

Testamento de doña Inés García, que había sido esposa de don Álvaro Sánchez de Ávila.

B.- ACS, IG 425, fols. 280r'-284ro

(fol. 280r ${ }^{\circ}$ ) Enno nome de Deus, amen, et da vendita gloriosa Sennora Santa Maria, sua madre, que eu tenno por sennora et por abogada. Sabean todos conmo eu, Ynes Garcia, muller que fuy de Alvaro Sanches de Avila, regidor que fuy da çibdade de Santiago, jazendo enferma en cama de aquela dolor et enfermedad corporal que a Nuestro Sennor aprobou de me dar, et temendome da ora da morte por que

297 Espacio en blanco. 
ey de pasar, sendo ben çerta et savidora que o non poso escusar et non sabendo o dia nen a ora en que a de ser, salbo quando for vontade de Deus, por ende faço miña manda et testamiento, et hordeno de meus bees conmo despoys de meu falesçemiento fiquen ven hordenados a seruiçio de Deus et $\mathrm{p}[\ldots]^{298}$ et a savde da miña alma.

Primeyramente mando a miña alma a meu Sennor et Salbador Ihesu Christo, que a conprou et redemio por lo su santo sangre justo et preçioso, et lle pido et suplico por la sua santa pasion e misericordia que me queyra perdoar los meus pecados et maldades que en danno de mynna alma fize et cometi, et aja misericordia con a miña alma; et rogo et pido por merçed a a gloriosa Virgen, Sennora Santa Maria, sua santa madre, con todos los santos et santas da gloria çeles/ (fol. 280v $\left.{ }^{\circ}\right)<$ tial $>$ que lle queiran por min rogar et que seja miña abogada a ora da miña morte, et o dia do gran juyzio.

Iten mando que me vestan en vn abito de tella branca con seu San Benito ven conplido; yten mando sepultar minas carnes pecadoras debaxo de vna pedra eno çimiterio de dentro da capela de Santa Maria do Perdon, a çerca do muymento do reverendisimo sennor arçobispo Don Lopo, que aja santa gloria, enna sepultura en que jaz meu primeiro marido, que fuy Juan Castellano, que Deus aja, regidor que fuy da dita çibdad de Santiago, e Justina Garçia, nosa filla, et mando que me digan o dia de miña sepultura misa cantada et no altar mayor do Apostol sennor Santiago et vaan os benefiçiados con responsos a miña sepultura et que me façan tanger os sinos da ser et de todos les paguen sua limosina da misa y responso e por los signos su salario acostumado ou conmo se avieren con meu herdeyro et conplidores; e asi a os septe dias, quarenta dias et anno et dia et mando que me digan eno dito dia ena dita capela de Santa Maria do Perdon et ena capela de San Juan Apostol donde soo freygresa fasta hos septe dias treinta misas cantadas et beinte resadas. Et mando que rezen o dia de meu falesçemiento e sepultura quinze salteyros por la miña alma et de meus padre et madre e do dito Juan Castelancio, mau marido que fuy, e de aqueles a quen soo obligada, e que os digan ou rezen clerigos o flayres de misa.

Et mando que desen de comer a os pobres eno dito dia pan, vino, carne o pescado, segun que for o dito dia ena casa, et den de comer a os lazarados que obieren buscar. Et mando que des lo primero dade miña sepultura fasta os septe dias que den de comer a doze pobres, a honrra dos ditos doze apostolos, me façan doze antorchas de çera para miñas honrras e das outras candeas e sescas, as que fizieren

298 Una palabra. 
menester. Yten mando que me digan a os septe dias duas misas cantadas et quatro misas rezadas e que den de comer a os probes segundo quiser o dia e que roguen a Deus por miña alma et de aqueles a quen soo obligada e asi a os quorenta dias et ano et dia.

Yten mando que os flayres et monges de todos los monesteyros de dentro desta çibdade e darredor dela e canonigos de Sar, que cada monesteyro me diga vna misa cantada a o dia de miña sepultura, et vaan os monges et flayres de cada mosteyro con responso sobre miña sepultura, et asi a os septe dias et a os quorenta dias et a o anno <et> dia, e les paguen de limosna a cada monesterio dos reales $(i)$ por cada misa e responso. Iten mando que me digan vn triintanario de misas enna dita capela de Santa Maria do Perdón por mina alma et de meu padre et do dito Juan Castelaao, meu marido que foy et de aqueles a quen soo obligada e o que digan clerigo ou flayre de boa vida onesta, e vaa con agua bieyta sobre miña sepultura, et lle paguen por limosina del trezientos maravedis vellos. Iten mando a o capelan de San Juan apostol, donde so feligresa, dozentos maravedis vellos, e mas por dezimos froyados vnha(i) dobla de oro. Iten mando a capela de Santa Maria de Perdon vna vestimenta nova de lenço con seu manto et estola et magniplos par que estea ena dita caoela para se deziren as misas con elas quanto d $[\ldots]^{299}$. Iten mando a o moesteyro de Sant Martiño outra vestimenta nova de lenço guarnida ansi mismo para que este enno dito monesterio para as misas e serviçio de Deus en quanto ela durar, e mando a os monxes do dito mosteyro dozentos maravedis vellos et que me digan vna misa cantada eno dito monesterio e rogues a Deus por miña alma. Iten mando a os / (fol. 281 ${ }^{\circ}$ ) capelanes da dita capela de Santa Maria de Perdon cent maravedis vellos et que roguen a Deus por min e me digan vna misa cantada enna dita capela o dia de mina sepultura ou en outro dia.

Yten mando a yglesia de Sant Giaan de Layno outra bestimenta de lenço nova para que este ena dita yglesia para se dezir con elas as misas e ofiçios devinos en quanto ela durar.

Yten mando para a obra da yglesia do Apostol Señor Santiago çen maravedis, e mando para o seu lume duas libras de azeite, e mando mays para o lume da dita capela de Santa Maria de Perdon duas libras de azeyte, e mando a todas las capelas da yglesia de Santiago que de detro dela e de dentro da dita çibdad e mosteyros de dentro a cada vn hua libra de azeyte para o lume, e mando a os mosteyros de Santa Clara e de Santa Maria de Belbis e de Santa Maria de Couso a cada vn veynte maravedis, e mando a o mosteyro de Santa Christina çincoenta maravedis e

299 Tres o cuatro letras. 
mando a os lazarandos da horden de Santa Marta e de San Lazaro de a par desta çibdad, ou en las <que> estoviere a o tempo de meu falesçemento, a cada horden çent maravedis vellos, e roguen a Deus por mina alma.

Yten mando a o moesteyro de San Domingo de Bonabal vn caliz de plata de vn marco e medio para que este eno dito monesterio para se dizir por el quanto durara as misas e que os flayres do dito mosteyro roguen a Deus por la alma de Gomez Garcia, meu padre, e minna.

Yten mando a os flayres do dito mosteyro çent maravedis vellos e me digan duas misas cantadas por la mina alma e do dito meu padre e vaan con responso e agoa byeyta sobre la sepultura do [...]gaz ${ }^{300}$ o dito meu padre, que jaz ante o coro do dito monesterio aç $[\ldots] 1^{301}$ cada estante e roguen a Deus por la sua alma e por la mina e de aqueles a quen soomos obligados. Yten mando a os flayres del monesterio de Sant Françisco desta çibdad tres avitos e que roguen a Deus por la miña alma, et mando outros tres avitos a os flayres do monesterio de San Lorenço desta çibdad e roguen a Deus por minna alma. Yten mando mays a o dito monesterio de San Lorenço vn paramiento dos dous que tenno, o mais novo, para que este no dito monesterio para poer quando poeren Nuestro Sennor en el $\mathrm{m}[. ..] \mathrm{o}^{302}$. Yten mando outro paramento a o monesterio de Santa Maria a Nova. Yten mando a o monesterio de San Payo d'Antealtares vna alcatifa grande para que este eno dito monesterio en la santchristia $[\ldots]^{303}$ para se serviren della en los altares e que os monxes do dito monesterio sejan obligados de dizir eno dito monesterio vna misa cantada por la alma do dito Alvaro Sanches meu marido, e vaan con responso e agoa vieyta sobre sua sepultura. Yten mando a o ospital de Santiago vn aliho e vn par de savaas, todo d'estopa, e vna manta blanca desas de casa e vn anteporta(i) verde e colorada que acharan en casa para cobrir a cama. Yten mando a o espytal de Santa Ana que hes a çerca da capela de San Fiis vna colcha e duas sabas d'estopa e duas mantas desas, que acharen por casa. Yten nomeo por voz e persona subçedente ena mellor via firme e mando que poso e devo nomear eno foro de Condide e da presentaçion da yglesia de Sant Giaao de Layño que tenno do mosteyro de Sant Martynno de Fora desta çibdad de Santiago a meu sobrino Francisco / (fol. 281v ${ }^{\circ}$ ) Gomes, veciño da vila de Noya, con o cargo do dito foro e por las maneras e condiçiones do contrabto de aforamiento que eu deles tenno. Yten mays nomeo por voz a o dito Francisco Gomez eno foro do casal de San Jubaas(¿) que he enna feligresia de Sant Martinno d'Ariins que tenno

\footnotetext{
300 Dos letras.

301 Una letra.

302 Cuatro o cinco letras en una o dos palabras.

303 Palabra de tres letras.
} 
de foro da capela que hes da capelania de don Juan Peres d'Oeys con o cargo do foro e por las maneras e condiçiones del. Yten mando por voz e persona subçedente segund que meeior poso e devo eno foro do casal de Pumarinno que tenno dos raçioneiros de Santi Spiritus a Cristina $\left(i^{304}\right)$ de Figueyroa, meu çolaço, e rogue a Deus por min, con o cargo de dito foro e por las maneiras e condiçions del. Yten nomeo por voz e persona subçedente segund que o mellor poso et devo nomear enno foro que tenno das casas que foron de Pero Leyteiro que son ena Rua do Vilar desta dita çibdad a Sancha, miña criada, muller de Juan Boo, platero, con cargo do foro e maneiras e condiçions del, e mandolle vna sortella d'ouro quebrada que la ten que tragar(i) por amor de min. Yten mando a Confraria dos Clerigos do Coro da Santa Yglesia de Santiago trezentos maravedis vellos, e que me digan vna misa cantada con seu responso o dia de miña enterraçion, e outro a os septe dias e asi a os quarenta dias e ano e dia. Yten mando mays a dita confraria e clerigos do coro aquela mina casa que esta ena Rua Nueba, junto con outra casa minna da hua parte e da outra parte con vna casa do meu sobrino Mynt. Garcia, que deus aja, e naquela miña casa agora mora Jacome do Vando, amo de Don Diego de Castilla, a qual dita casa lles mando para sempre con tal condiçion e cargo que me digan en cada mes do añon para sempre huna misa rezada con seu responso, a qual digan ena capela de Santa Maria do Perdon e o responso sobre miña sepultura ena dita capela con agoa bieyta por la miña alma e de meu padre e de aqueles a quen soo obligada e que digan a dita misa en cada mes enno dia que acordaren e a señalaren con acordo de meu heredeyro para sempre segundo dito he. Yten mando a mina prima Guiomar Suares dez doblas d'ouro ou sen balor e huna colcha das duas que teño. Yten mando a Violante, miña criada, que agora comigo non mora, vna aljuba de Londres nova e vna saya de vayxo de palmilla nova e vna con ardalgadon(i) e vna co çere(i) e vn colchon d'estopa e vn par de sabaas e vn cabeçal e vn caldeyro e vn puchel d'estanno d'açumbre e vna viha das pequenas e dos mill pares de brancas para su casamiento e vna pelica. Yten mando a Alvaro de Layan, meu criado, vna capa e vn sayo de palmillae un gibon de sultan. Yten mando a meu sobrino Gomez Garcia, fillo vastardo do meu sobrino Martin Garcia, regidor que fuy da vila de Muros, que Deus aya, para ajuda d'estudiar e de aprender gramatica dos mill maravedis de pares de brancas. Yten mando a Tareyja Garcia, mina sobrina, filla legitima do dito Martin Garçia, meu sobrino, que Deus aja, aquela casa que teo ena Rua Nova desta dita çibdad, a qual de vna parte esta junta con outra minna casa que en el testamiento mando a os clerigos do coro da Santa Yglesia de Santiago e doutra parte con casas de $* * * 305$, a qual casa de min

${ }^{304}$ Se abrevia $C^{\text {a }}$, con lo cual puede ser Cristina o Catalina. 
ten agora aforada Francisco Rodrigues, fillo de Ruy de Lugo arcediano que fuy do arcediago de Deça, que Deus aja, e se a dita casa valer vinte mill pares sobrantes que a aja / (fol. $282 \mathrm{r}^{\circ}$ ) por eles para ajuda de seu casamento con a miña beyçon, e se tanto no valer que con ela se cunpla e faga conplimiento meu herdeyro dos ditos vinte mill maravedis de pares de brancas. Yten mando que vejan a clavsola que me fizo o dito Alvaro Garçia (sic) d'Abila, meu primeyro marido, que Deus aja, e das cousas que en ela me es cargo el alcalde mayor, seu herdeyro et as demanden e vna conta escrita por Juan Garcia, notario desta çibdad, por la qual me es a cargo o dito alcalde mayor de diez doblas d'ouro por vna cadea dourada, que foy spen[di]da por lo dito meu marido Alvaro Sanches, e vna cruz d'ouro con çertas perlas e vna pedraça si es ouro, e doutras muytas cousas mi[nna]s a cargo que non estan nomeadas ena dita conta. Yten por quanto Juan Castelano, meu primeyro marido (sic), que Deus aja, prestou a Tareija Garçia de Cordova vn plato de plata que pesaba dez honzas, dezendo a dita Tareija Garcia que llo prestara que o avia menester, para liberaçion das[... $]^{306}$ de Fernan de Vaamonde, plateyro, estando presente, que viña en conpañia da dita Tareysa Garcia, Costança Roso, muller do dito Fernan de Vaamonde, e de cada çerto tempo a dita Tareija treuxo vn copete que pasaria dous marcos e o enpennou a o dito Juan Castelao por quatro doblas d'ouro des contadas as ditas dez honças de plata e las quatro doblas d'ouro da valor do dito copete mando que se lle paguen o mays a a dita Tareysa Garçia. Yten, por quanto que Juan Castelaao, meu primeiro marido, e $[\ldots]^{307}$ marido de minna tya Costança Gil, cujas animas Deus aja, e avia algunas costas e devdas de vna parte a outra e ansimismo con a dita minna tia Costança Gil, mando que meu sobrinno Francisco Gomez, meu herdeyro, e meu primo Lope Gomez meu conplidor, fillo da dita Costança Gil, as ditas quantias e has fagan e tasen como vieren que es mellor a qualesquier cargo sus consiençias, e o dito Lope Gomez ten de min en prendas vnas doas d'ouro das quales tenia a dita sua madre miña tia e se lle pague a o dito Lope Gomes lo que asi averiguaren por conta el e o dito mau herdeyro que se deve. Yten encomendo a o dito Francisco Gomez, meu sobriño e herdeyro e lle layxo por la myña veyçon e de aqueles de quen deçendemos que o dia de Todos los Santos ou en aquela manera aja memoria da miña alma e de Gomes Garcia, meu padre, seu avoo e de Juan Castelano y me fagades tres misas cantadas con seus responsos e de de comer a doze probes eno dia ou dias que dize-

305 Se deja un hueco en blanco para dos o tres palabras.

306 Tres o cuatro letras.

307 Dos palabras; con seguridad un nombre. 
ren as ditas misas, en reberençia dos doze apostolos. Yten mando a Catalina Sanches, muller de Gomes de Ventosa, vn anillo douro e vna touca(i) de seda.

Yten fago e constituyo por meu herdeyro vniversal en todos los outros meus bees mobles e rayzes en esta minna manda primeiramente conplida e devdas pagas a o dito Francisco Gomez, meu sobrinno, para que hos aja et lebe para senpre con a minna veyçon e faga ven por minna alma e de meu padre e de aqueles a quen soo obligada; y faço por complidores desta miña manda a o dito Francisco Gomez e a meu primo Lope Gomez de Marçoa, / (fol. $282 \mathrm{v}^{\circ}$ ) notario desta dita çibdad, para que a cumplan por meus bees e sen sen (sic) dano deles, e mando a o dito Lope Gomez por seu traballo o meu anel douro que ten tres pedras: vna esmeralda e dos valays, que tenga por amor de min.

E esta dou e entrego por miña manda e testamento e minna postrimeyra vontade, e revoco e anulo e dou por $[\ldots]^{308}$ todas e quales quer outras mandas e codeçillos que eu teno ou aja feytos e otorgados antes deste, ansi por escripto como por palabra, e qualquer mandamento que seja para que non vala nin faga fee en juyzio nin fora del en ningun tempo nin por alguna manera, salbo esta mina manda e testamento que agora faço e outorgo por ante el notario e testemoyos, que quero e mando que valla ansi como miña manda, et se non valer como manda que valla como condiçilo ou como miña vltima e postromeyra voontade ou como mellor posa et deva valer de dereito, ena qual digo et declaro que he conplido meu seso e vltima voontade e aparto todolos outros meus parentes e parentas en çinco soldos a mas de meus bees no se estendan. Et conto esta miña en quinentas dobras douro que peyte e pague persona quen quer que contra ela for ou pasar, a metade a meu herdeyro e a outra metade para a camara do señor arçobispo de Santiago para que a fagan complir et exsecutar. E a pena pagada ou non pagada todavia esta miña manda e testamento e postrimeira vontade e as cousas e legatos en ela contiudas seja firme e valla para todo sempre. Yten mando a Santa Cruzada vn real de plata e a mays de meus beens que non se estenda.

Que fuy feyta e otorgada en la çibdad de Santiago, dentro das casas de morada da dita Ynes Garçia, que son sitas ena Rua Nova da dita çibdad, donde vibe el bachiller Martin de Rianjo, a doze dias del mes de junio, año del nasçimiento de Nuestro Señor Ihesu Christo de mill e quatroçientos e noventa e tres annos.

Presentes a ello por testemoyos, llamados e rogados, el bachiller Martin de Rinajo e don frey Alvaro Yanes de Figueyroa, abad del monesterio de Çinis, e Rodrigo Suares, clerigo de Sant Martino de Callobre, e Jacome de Luou, e Juan de Berançio Rodrigues(i), e Rodrigo de Syeyro, puxoteyro, e Pero Herrador, e Juan da

308 Palabra de cinco o seis letras. 
Costa, notario apostolico, e Juan de Monteroso, clerigo de Santa Maria de Paradela desta diocesis de Santiago, e Juan Alvares, labrador, morador en la felegresia de Sant Christoboo do Ejo.

1499, febrero, 18. Santiago de Compostela.

Ante el Cabildo, Francisco de Treviño, compridor de las mandas testamentarias de Álvaro Sánchez de Ávila, se obliga para igualar la cantidad que se estaba percibiendo por los dos aniversarios a celebrar por el fallecido tenente de A Rocha Forte.

A.- ACS, IG 477 , fol. $160 r^{\circ}$.

En este dia Francisco Treuinno, regidor e vecino de Santiago, dio su poder complido al [...] para que juntamente con el sennor don Diego D[... $]^{309}$, mestre escuela de la yglesia de Santiago, nombrado por los señores del Cabildo de la dicha yglesia por dar, conçertar e ygualar la dinero/ los dos aniversarios que el alcalde de la Rocha, \Alvaro Sanches/, mandó asentar en su testamento e faser todo el que faria por serto, siendo prometo de lo aver por firme e no ir contra ello, sub obligaçion de sus bienes, que por ello obligó. E otorgó poder la s[... $]^{310}$.

Testigos Rodrigues (?) Abraldes e Francisco de M[... $]^{311}$.

15

S. XV. [Santiago de Compostela].

Aniversario por don Álvaro Sánchez de Ávila, tenente de A Rocha y enterrado en San Paio de Antealtares, a celebrar en la iglesia de Santiago en 28 de abril, recogido en el Tumbo de Aniversarios, pagando por la celebración 100 libras.

A.- ACS, CF 13, fol. $16 \mathrm{r}^{\circ}$.

A.- ACS, CF 12, fol. 39r ${ }^{\circ}$.

In ista XXVIII die mensis aprilis fiat anniversarium pro anima honorati viri domini Alvari Santii de Avila, quondam tenetis in omagio Rumpem Fortem per reverendisimo domno archiepiscopo compostelano, dantur centum librarum sol-

\footnotetext{
309 Una palabra.

310 Una palabra de cuatro o cinco letras.

311 Una palabra de cinco o seis letras.
} 
vuntur per bonis suis mense capitulari pro honorato domno Francisco de Trevinno, rectore compostellano, herede suo, datis. Est sepultus in sinistra capella ecclesie Sancti Pelagii; fiat processio ad Quintani apud ianua ipsius monasterii.

\section{6}

S. XV. [Santiago de Compostela].

Aniversario por don Álvaro Sánchez de Ávila, tenente de A Rocha y enterrado en San Paio de Antealtares, a celebrar en la iglesia de Santiago en 6 de septiembre, recogido en el Tumbo de Aniversarios, pagando por la celebración 100 libras.

A.- ACS, CF 12, fol. $7 v^{\circ}$.

A.- ACS, CF 13, fol. $33 v^{\circ}$.

In ista sexta die mensis septembris fiat anniversarium pro anima honorati viri domini Alvari Sanctii de Avila, quondam tenetis in homagio Rumpem Fortem per archiepiscopo compostelano, dantur centum librarum solvuntur per bonis suis mense capitulari pro honorato viro Francisco de Trevinno, rectore compostellano, herede suo. Processio ad Quintanam apud ianuam Sancti Pelagii, quia ipse sepultus est in ecclesia Sancti Pelagii in capella sinistra partis.

\section{7}

1514, diciembre, 6. Santiago de Compostela.

El Cabildo compostelano cede en foro las propiedades de la tenencia de Santa Baia de Vedra, a Álvaro Núñez, secretario de Su Magestad, y a su esposa Isabel Sánchez de Ávila, nieta de Álvaro Sánchez. Tal tenencia estaba integrada por propiedades que había tenido el propio alcaide de Rocha Forte. Se hace referencia, además a la resolución de un pleito entre el Cabido y dicho matrimonio, que afirmaba tener determinados derechos sobre las posesiones.

A.- ACS, IG 479, fol. $69 \mathrm{v}^{\circ}$.

En este cabildo los dichos sennores dieron la thenencia de Santa Vaya de Vedra, con su sennorio, vasalage, jurdicion e coto de lo a ella anexo e pertenesçiente al sennor Juan Lopez de Valladolid, su $[\ldots]^{312}$ y con[... $]^{313}$, que estaba presente $a d$ vitam et refectionem, para efecto que la aya Alvaro Nunnez, secretario de la

312 Palabra de tres o cuatro letras.

313 Dos o tres letras. 
avdiençia real, por su vida e de su muger, e aya en ella los seys mill maravedies que el cabildo lle prometio e dio en la mesa capitular por la çesion que fizo del derecho que tenia, sy alguno tenia, de los bienes e hazienda del alcalde de la Rocha. La qual dicha tenencia dixeron los dichos sennores que llebe e aya el dicho Alvaro Nunnez por la dicha su vida e de la dicha su muger con el dicho sennorio, vasalaje, jurdiçion e con todo lo a la dicha thenençia anexo e pertenesçiente.

18

1514, deciembre, 20. Santiago de Compostela.

El Cabildo compostelano entrega a Álvaro Núñez las mandas dispuestas por Francisco de Treviño, ya fallecido, para Isabel Sánchez de Ávila, nieta de Álvaro Sánchez y de la que era tutor.
A.- ACS, IG 479, fol. $72 v^{\circ}$

En este cabildo los dichos sennores mandaron dar al secretario Alvaro Nunnez los fueros y escripturas de los rescriptos que fizo Francisco de Trevinno a Ysabel Sanchez de Avila, su muger, los quales le pertenesçen, y que el dicho s[e necesito](?) de el testamentiento (sic) del alcalde de la Rocha, que tiene en su poder, y que quien le diere las dichas escripturas reçiba de el dicho testamento.

Testigos el sennor chante e el cardenal Diego Gutierrez. 